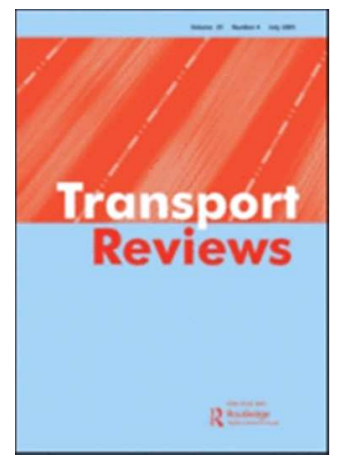

\title{
What Cognitive Mechanisms Predict Travel Mode Choice? A Systematic Review with Meta-Analysis
}

\begin{tabular}{|r|l|}
\hline Journal: & Transport Reviews: A Transnational Transdisciplinary Journal \\
\hline Manuscript ID & TRV-2016-0059.R1 \\
\hline Manuscript Type: & Original Article \\
\hline Keywords: & Travel mode, systematic review, meta-analysis, car use, transport policy \\
\hline \multicolumn{2}{|c}{} \\
\hline
\end{tabular}

SCHOLARONE ${ }^{\text {Ix }}$

Manuscripts 


\section{Introduction}

Increasing reliance on car use is associated with substantial negative impacts on human health and the environment, especially in cities (Gärling \& Friman, 2015). For instance, noncar commuting, such as walking and cycling and using public transport (PT) can contribute to daily recommended levels of physical activity (Sahlqvist, Song, \& Ogilvie, 2012; Wener \& Evans, 2007). Active transport and use of PT also reduces pollution. For instance, use of PT can result in $45 \%$ less $\mathrm{CO}_{2}$ and $48 \%$ less nitrogen oxide emissions compared to private vehicle use (Shapiro, Hassett, \& Arnold, 2002). Unfortunately, however, the use of cars for school runs (Ulfarsson \& Shankar, 2008), leisure purposes (Van Acker, Mokhtarian, \& Witlox, 2011), tourism mobility (Ram, Nawijn, \& Peeters, 2013) and most notably for commuting to work (Panter, Desousa, \& Ogilvie, 2013), is increasing and current trends suggest a doubling of global car ownership by 2040 (IEA, 2015).

To understand how interventions could effectively promote alternative travel mode choices, researchers have investigated several predictors of car use and alternative travel modes including, geographic (Park, Kang, \& Choi, 2014), economic (Frank, 2004) and psychological factors (Gardner \& Abraham, 2008). Narrative reviews, have synthesised determinants of car use across disciplines, concluding that travel time and cost, sociodemographic and spatial characteristics and car availability are key antecedents of travel mode choice (De Witte et al., 2013; Frank et al., 2008). Identifying psychological changes that could increase use of alternatives to car travel (henceforth abbreviated as 'non-car-use') provides a theoretical basis for so-called 'soft' interventions to promote voluntary behaviour change (Fujii, Gärling, \& Kitamura, 2001). Such interventions, can be cost-efficient and quickly implemented compared to, for instance, engineering solutions (Cairns et al., 2008; Richter, Friman, \& Gärling, 2010). In reality, policy strikes a balance between the two. 
Social-psychological theory has identified a range of potentially-modifiable cognitive mechanisms that can be targeted in travel mode choice interventions (Bamberg, Fujii, Friman, \& Gärling, 2011). Most commonly, the Theory of Reasoned Action (Fishbein \& Ajzen, 1975) and its successor, including perceived behavioural control (PBC), the Theory of Planned Behaviour (TPB) (Ajzen, 1991) have both been tested. Attitudes, subjective norms and $\mathrm{PBC}$ are products of underpinning beliefs and many beliefs related to safety, convenience, time flexibility, practicality, health, accident risk and comfort have been investigated as antecedents of travel mode attitudes (e.g. Mann \& Abraham, 2012; Gärling et al., 1998; Bamberg et al., 2007; Heath \& Clifford, 2002; Şimşekoğlu et al., 2015).

Understanding of the role of normative beliefs, in particular, has been furthered by development of the Norm Activation Model (NAM) (Schwartz, 1977). This model's core construct is personal norms or the "individual's internalised moral rules" (Parker, Manstead, \& Stradling, 1995, p. 129). Dunlap and Van Liere (1978) propose, that "to the extent that concern for the well-being of other humans is aroused, we would expect traditional moral norms which regulate interpersonal behavior to influence environmental behaviors" (p.175). Schwartz (1977) argues for a direct influence of personal norms on behaviour, as opposed to the mediating role for intentions proposed by the TPB. According to the NAM, personal norms influence behaviour when ascription of responsibilities and awareness of consequences are activated. The former refers to a person's self-ascribed responsibility to, for instance, refrain from using the car. The latter describes the level of awareness of environmental damage caused by human influences.

The Value-Belief-Norm (VBN) model (Stern, Dietz, Abel, Guagnano, \& Kalof, 1999), clarifies how values are related to behaviour in the NAM. Stern et al. (1999) propose that biospheric, altruistic and egoistic values may all be related to environmentally-relevant behaviour. 
It has been argued that these models and other rational choice theories do not adequately represent behaviour patterns that may be regulated by less conscious processes (Sniehotta, Presseau, \& Araújo-Soares, 2014; Triandis, 1977). For instance, when behaviours are practiced in stable environments over time, they can be automatically initiated by environmental prompts with little or no conscious deliberation (Strack \& Deutsch, 2004). Thus, since daily travel tends to occur in stable contexts, transport mode choice may, over time, become less of a "choice" and more of a habitual response executed with little reflection (Gardner, 2009; Gärling \& Axhausen, 2003). Habit was first introduced in Triandis' (1977) Theory of Interpersonal Behaviour and it has been shown that the formation of habits may change the cognitive mechanisms underpinning travel (Verplanken, Aarts, van Knippenberg, \& van Knippenberg, 1994).

A limited number of systematic reviews have evaluated interventions that implemented evidence on the importance of a range of cognitive mechanisms to change transport mode choices, but evidence of effectiveness of such interventions is sparse (Arnott et al., 2014; Graham-Rowe, Skippon, Gardner, \& Abraham, 2011; Macmillan, Hosking, Connor, Bullen, \& Ameratunga, 2013). This implies that our understanding of travel mode choice is incomplete. Reviews of effectiveness may not elucidate which interventions work best under varying circumstances. For instance, as Bamberg (2006) notes, "summarizing and comparing average intervention effects per se provides little insight into the conditions and mechanisms mediating these effects" (p. 821). More integrative systematic reviews are needed so that intervention designers can identify relevant cognitive mechanisms linked to driving decisions and circumstances in which those mechanisms might be more susceptible to modification.

So which potentially-modifiable psychological/ cognitive mechanisms should be targeted by interventionists attempting to change travel mode choice? Gardner and Abraham 
(2012) provide a useful review of the associations between psychological constructs and car use but were limited to reviewing 23 available studies. We sought to provide a comprehensive review examining associations between modifiable cognitions and both car use and non-car-use. We will use the term "cognitive mechanisms" to refer to a set of psychological measures that have been related to car use and non-car-use across this literature. This includes implicit and explicit measures of beliefs (including normative beliefs), attitudes (including feelings), motives and self-reported habitual action.

\section{The Present Study}

We updated and extended the work of Gardner and Abraham (2008) by taking account of a wider range of potentially-modifiable cognitive mechanisms (henceforth abbreviated to "cognitive mechanisms") based on a larger sample of studies. The present review distinguished between correlates of car use and non-car-use (e.g., use of public transport instead of driving) and examined potential moderators. Five questions were addressed: (1) which cognitive mechanisms have been used to explain car use and non-car travel, (2) how methodologically rigorous are available studies, (3) which theories do identified cognitive mechanisms represent, (4) how strong are bivariate associations between specific cognitive mechanisms and car use/ non-car-use, and (5) is strength of these associations moderated by contextual factors such as study location, journey type and travel measure (e.g., 'typical car use' versus 'actual car use').

\section{Methods}

Many narrative reviews usefully summarise existing literature but only in relation to specific review questions. In this study we conducted a systematic review to ensure a more comprehensive and transparent summary of the literature (Young et al., 2002; Tranfield et al., 2003). In addition, we conducted a narrative synthesis of identified cognitive mechanisms 
and, based on this, a meta-analytic synthesis of (zero order) bivariate correlations between categories of cognitive mechanisms and car use. The review was conducted in accordance with the guidance provided by the University of York, Centre for Reviews and Dissemination for undertaking systematic reviews (Khan, Ter Riet, Glanville, Sowden, \& Kleijnen, 2001).

\section{Inclusion Criteria}

We included papers that (1) provided at least one quantitative measure of an association between a cognitive mechanism and a measure of car use or non-car-use, (2) were published in English in a peer-reviewed journal, (3) sampled a range of the adult driving population ( $>18$ years), (i.e. excluding studies that investigated only e.g. older adults ( $>60$ years), particular households, people with impaired mental and physical abilities or non-license holders), and (4) focused on any journey type (i.e. excluding studies that focused exclusively on e.g. school runs or holiday travel). No limitations were set on publication date, study design or other socio-demographic population characteristics. When multiple papers reporting results based on a unique data set were identified, the paper with the most comprehensive methodological description was retained for analyses. Where necessary, secondary articles reporting on the same data set were used to complete data extraction. Supplementary File, Chapter 1 provides further explanation of our inclusion criteria.

\section{Search Strategy}

The systematic search was closed in September 2015. Ten databases were searched for keywords, abstracts and titles including the meta-databases EBSCO, Web of Knowledge, Transport Research Board and ProQuest. The search used 77 keywords related to travel mode choice (e.g. "modal choice"), transport (e.g. "car") and social-psychological categories (e.g. "antecedent"). Search terms and Boolean combinations were customised to accommodate 
differences across databases. An illustration of one systematic search can be found in Supplementary File, Chapter 1, Table S1. Ancestry and descendency searches were performed by hand-searching reference lists of included key papers and systematic/narrative review articles as well as citation searches using Google Scholar until no new records could be identified.

\section{Study Selection and Data Collection}

The systematic search strategy identified 4,156 records which were initially screened for title as well as abstracts. A second reviewer independently screened a random selection of 306 (of 3005, 10\%) excluded records and agreed, in all cases, that none of those papers should have been included in the review. Full text screening of 388 articles was completed based on the pre-defined inclusion criteria. A final number of 43 studies were deemed eligible for inclusion. Eighty-six studies (43 included and 43 excluded) were independently screened by a second coder. The AC1 statistic (Gwet, 2002) was used to calculate the degree of agreement between two coders and a score of 0.93 indicated good inter-rater reliability. Disagreements were resolved by consensus or in consultations with a third researcher.

Extracted information included measures of cognitive mechanisms, detail of study characteristics, statistical analysis, dependent car use and non-car use measures and methodological quality criteria. Longitudinal data were extracted from the most recent set of measures. Only baseline measures or control group data were extracted from studies with an experimental design. Wherever possible, Pearson's correlation coefficients were extracted; otherwise Spearman's correlation coefficients or point-biserial correlations were used. Authors were contacted if relevant information could not be extracted and studies were excluded from meta-analyses if effect sizes were unobtainable. Of 43 eligible studies, 35 could be included in quantitative synthesis. 
Included papers are marked with one asterisk in the reference list and with two asterisks if data was included in meta-analyses. Figure 1 illustrates the steps of the study selection process in more detail.

Figure 1. Preferred Reporting Items for Systematic Review and Meta-Analyses (PRISMA) flowchart

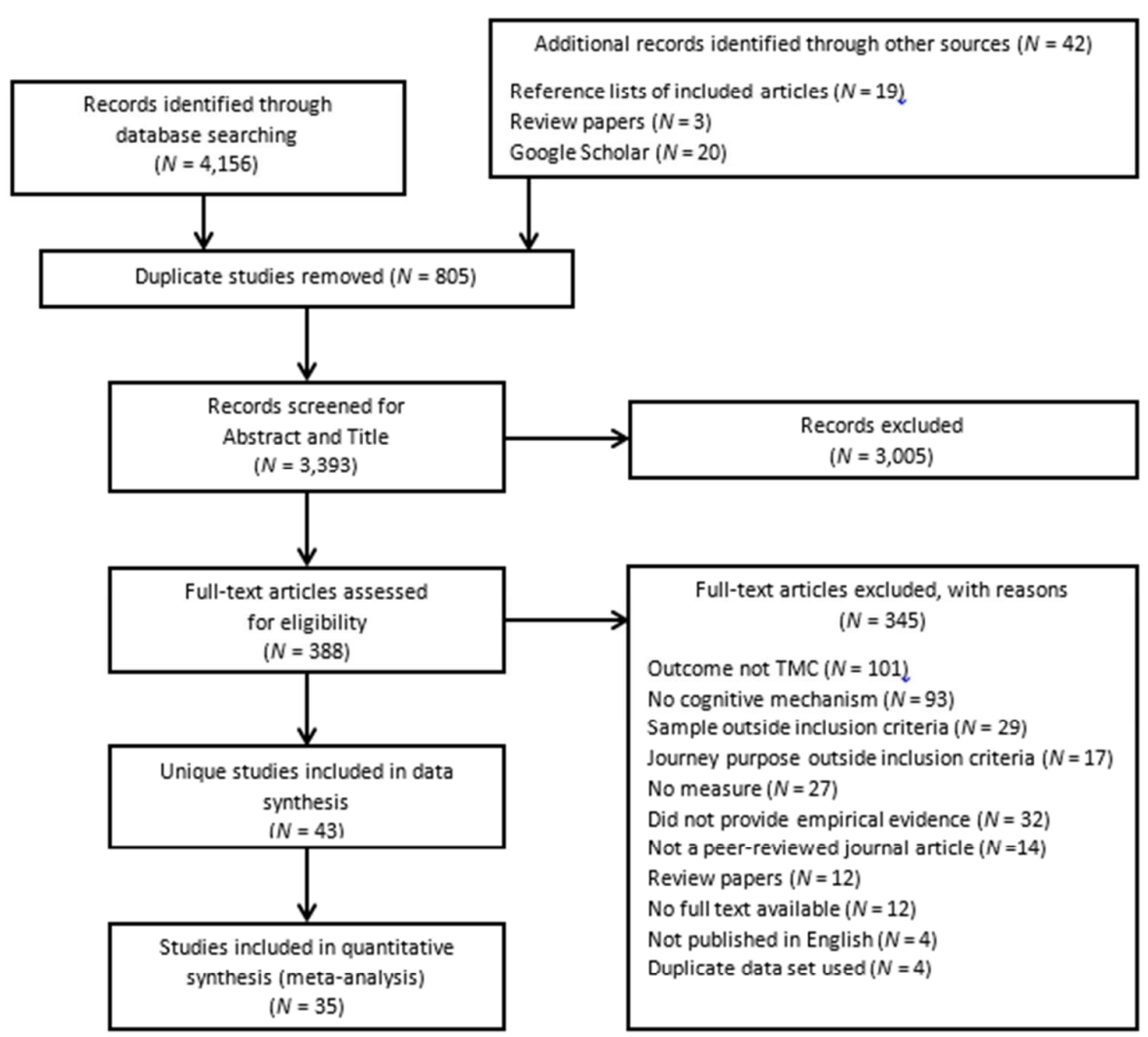

\section{Methodological Quality Assessment}

The majority of included studies were cross-sectional surveys. No suitable quality assessment tool was found to assess such survey studies. We therefore applied three criteria that were highlighted across six previous studies recommending bias assessment in correlational studies (EPHPP, 1998; Gautheir, 2003; NHLBI, 2014; Pace et al., 2012; von Elm et al., 2014; Wong, 
Cheung \& Hart, 2008). We have adopted the most common criteria across these validated quality assessment tools. First, was the sample size sufficiently large to find the hypothesized effects? Two criteria were used: (1) use of power analyses to guide sample size selection or; (2) a sample size greater than 200 if path analysis or structural equation modelling (SEM) were employed (Hoelter, 1983, Kline, 2011, Garver \& Mentzer, 1999). Second, was the sample representative of the target population? Third, did the study use reliable and valid measures as assessed by use of previously-validated/tested/used measures and reporting of internal scale reliability $(\alpha>0.6)$ (Gliem \& Gliem, 2003). Studies could score 1 point for of the first and second criteria. In assessing question 3, each measure of a cognitive mechanism was assessed separately and contributed to a single ratio of valid//reliable measures for each study. Hence, studies that included multiple measures could score between 0 and 1 point. Single-item measures were deemed not applicable for reliability assessment, hence not included in the score. A score of 0 was assigned if the criteria were inadequately reported, unclear or absent. Studies that achieved an overall score $>2,1-2,<1$ were rated as high, medium or low quality, respectively. We did not exclude studies on the basis of low quality scores but used the criteria to highlight areas of potential bias. A detailed definition of assessment criteria can be found in the Supplementary File, Chapter 3, Table S4.

\section{Data Synthesis}

A narrative synthesis was conducted (Popay et al., 2006) by qualitatively summarising extracted data to identify categories of cognitive mechanisms. In addition, a meta-analysis of correlation coefficients was undertaken to summarise effect sizes for each identified cognitive mechanism. Random-effects analyses were undertaken, assuming that not all study effects are homogenous (Hunter \& Schmidt, 2004). 


\section{Effect size analysis and multiple measures}

Pearson's correlation coefficient $r(N=30)$, the point-biserial correlation $r_{p b}(N=4)$ and Spearman's rank correlation coefficient $\rho(N=1)$ could be obtained from a total of 35 studies. In order to assign more weight to studies that carry more information, i.e. had larger sample sizes, the meta-analysis produced a weighted average effect size $\left(r_{+}\right)$. A $95 \%$ confidence interval was used to infer statistical significance. Pooled effect sizes are interpreted in accordance with thresholds proposed by Cohen (1988) where $r_{+} \geq .10, r_{+} \geq .30$, $r_{+} \geq .50$ and $r_{+} \geq .70$ qualify as small, medium, large or very large effects, respectively.

Our meta-analytic procedure frequently included more than one effect size per cognitive mechanism that was extracted from the same study (Myrtek, 1995; Pole, 2007; Wolf, 1986). For example, van Vugt et al.'s (1995) study measured the association between subjective importance of the environment and of public health using two different scales. Although the scales produced two different effect sizes, they are not independent of each other. Therefore, we combined those study effects a priori to obtain an average effect (Borenstein et al., 2009). Consequently, we only used one (average) effect size for metaanalysis for which we extracted two associations at first. Hence, $k$ refers to the number of unique associations tested. Meta-analysis was performed where $k \geq 3$. While conclusions cannot be drawn from $k=2$ analyses (Ryan, 2013), all these analyses are presented for comparative purposes.

\section{Test of homogeneity and bias}

Chi-squared was used to test for heterogeneity. We expected $X^{2}$ to have a value at least as high as its degrees of freedom and $p>.05$ for studies to be considered homogeneous. For ease of interpretation, we also calculated the heterogeneity index $I^{2}$ to summarise inconsistencies across studies (Burnette, O’Boyle, VanEpps, Pollack, \& Finkel, 2013). This 
statistic describes the variation across studies as a result of heterogeneity rather than chance (Higgins \& Thompson, 2002) with higher percentage values demonstrating greater heterogeneity of effect sizes. $I^{2}$ values were interpreted in accordance with Higgins and Green (2009), whereby values between $0-40 \%, 30-60 \%, 50-90 \%$ and $75-100 \%$ represent no, moderate, substantial and considerable heterogeneity, respectively.

Egger's regression test (Egger, Smith, Schneider, \& Minder, 1997) and interpretation of funnel plots was used, wherever possible, to detect evidence of publication bias (Rosenthal, 1979; Begg \& Mazumdar, 1994). Bias was considered to be present if the intercept significantly $(p<0.1)$ differed from 0 . Some analyses had insufficient numbers of studies for the test to be carried out so that results cannot be reported consistently.

\section{Results}

\section{Study Characteristics}

Included studies $(N=43)$ were predominantly cross-sectional surveys $(N=26,60.5 \%)$ that recruited, on average, 584 participants, with a slight over-representation of female participants (54\%). Across all studies, a minority $(N=7,16.3 \%)$ used student-only samples. The majority of studies were conducted in Europe $(N=36,83.7 \%)$ with contributions primarily from Germany $(N=13)$, the Netherlands $(N=8)$ and the UK $(N=7)$. Other studies were conducted in USA $(N=3)$, Australia $(N=3)$ and Canada $(N=1)$. Approximately one quarter of the studies $(N=10,23.3 \%)$ were conducted before the year 2000 . Detailed information on individual study characteristics can be found in the Supplementary File, Chapter 2, Tables S2 and S3.

\section{Setting, Journey Characteristics and Dependent Measures}

Thirty-eight studies (88.4\%) reported geographic settings $(N=38)$, of which $27(71 \%)$ were 
conducted in urban areas, three used rural samples and eight mixed rural, suburban and urban samples. Studies that included rural, suburban or a mix were aggregated and entered as nonurban studies in meta-analyses.

Various journey types were considered. A large number of studies focused on commuting trips only $(N=19,44.2 \%)$. The remaining 24 studies were aggregated as noncommuting journeys, of which shopping $(N=7,30.4 \%)$ and leisure trips $(N=6,26.1 \%)$ were the most frequent.

A variety of simple self-report car use and non-car-use measures were considered. A continuous measure of "typical car use" was employed by 30 studies $(69.8 \%)$, e.g. "how many times during the last week have you used the car?" (5-point scale seldom-always) or "In the last week, how many of your journeys were made using a car?" (5-point scale all journeys - no journeys). Thirteen studies (30.2\%) used self-administered travel diaries (over several days or weeks) to log multiple trips and modes and were summarised as "actual car use" studies. Continuous measures were derived by calculating a ratio, e.g. the sum of reported journeys made by car divided by the total number of reported journeys. Dichotomous measures $(N=7,16.3 \%)$ were used where, e.g. a value of 1 was given if a participant used PT and zero for car use.

\section{Measures of Potentially-Modifiable Cognitive Mechanisms (Research Question 1)}

Overall, 333 associations were found between (1) a cognitive mechanism measure and (2) a measure of car use/ non-car-use frequency or intensity. The number of associations reported per study ranged from one (Davidov, 2007; Tischer \& Phillips, 1979; Verplanken, Walker, Davis, \& Jurasek, 2008) to 20 (Mann \& Abraham, 2012) per dependent variable with an average of seven. One study tested 36 associations across three different car use measures (Van Acker et al., 2011). Later studies tended to measure more cognitive mechanisms per 
dependent measure (see Supplementary File, Chapter 4, Figure S2).

Operationalisations of non-car-use cognitive mechanisms varied considerably. For example, considering attitudes towards non-car-use travel, some studies concentrated only on one mode such as train travel (Verplanken et al., 1994) or PT in general (Nilsson \& Kuller, 2000), while others measured attitudes towards using PT instead of the car (Bamberg, 2006; Matthies, Klöckner, \& Preissner, 2006). Studies also concentrated on attitudes towards reducing the number of journeys (Abrahamse, Steg, Gifford, \& Vlek, 2009), not using the car (Gardner \& Abraham, 2010), or using other forms of transport instead of the car (Harland, Staats, \& Wilke, 1999). Two studies measured attitudes towards the use of active modes, e.g. cycling (Haustein \& Hunecke, 2007) and walking/ cycling (Van Acker et al., 2011) as separate variables in addition to PT use.

This range of conceptually and psychometrically different measures of cognitive mechanisms was aggregated into meaningful categories. We applied a similar coding scheme as used in previous meta-analyses (e.g. Hagger, Chatzisarantis, \& Biddle, 2002) in order to maintain continuity and transparency of categorisation. A second independent researcher categorised $65 \%$ of all measures and coders agreed on $88 \%$ of classified measures.

Disagreements were resolved through discussion. The number of studies and reported associations per cognitive mechanism can be found in the Supplementary File, Chapter 4, Table S6. Supplementary Table S7 (Chapter 4 in the Supplementary File) shows an overview of the emerged categories including a more detailed definition and examples.

\section{Methodological Quality Assessment (Research Question 2)}

Study quality was assessed for 43 studies and a mean score of 1 (range: 0 to 3 ) indicated a low to medium overall study quality. Seven studies (16.3\%) could be classified as high quality, 18 studies (41.9\%) as medium and the remaining $18(41.9 \%)$ as low quality. Detailed 
scores for individual studies can be found in Supplementary File, Chapter 3, Table S5.

\section{Sample size}

Only 9 of 12 studies which performed SEM or path analysis used a sufficient sample of 200 or more. Of those that did not perform SEM or path analysis, only three of $31(9.7 \%)$ reported undertaking a power calculation prior to data collection of which two achieved the required sample size.

Sample representativeness

Seven studies (16.3\%) used a representative sample of the target population. One third of included studies ( $N=14,32.5 \%)$ acknowledged having used samples that could not be described as representative and $22(51.2 \%)$ did not discuss sample representativeness.

\section{Validity/reliability}

The most frequent previously-validated measure used was the Response Frequency Measure (RFM) of habit (Verplanken et al., 1994) used in ten (23.3\%) studies. Overall 32 (74.4\%) studies used at least one previously-validated/tested/used measure. Of 214 measures eligible for reliability evaluation, 87 (40.6\%) achieved acceptable internal reliability (Cronbach's alpha $>0.6)$. We were unable to determine scale reliability for half of these measures $(N=$ $108,50.47 \%$ ) due not reported data.

\section{Use of Theoretical Frameworks (Research Question 3)}

Twenty four studies $(55.8 \%)$ were explicitly based on an underlying theoretical framework and eight multi-component theories were applied. Studies used measures derived from Ajzen's (1991) TPB $(N=16,66.7 \%)$, the habit-extended Theory of Interpersonal Behaviour by Triandis (1977) $(N=1,4.2 \%)$, Schwartz' (1977) NAM $(N=6,2 \%)$, Stern et al.'s (1999) 
modified VBN model $(N=1)$, Stryker's (1980) Identity Theory $(N=1)$, Kelley and Thibaut's (1978) Interdependence Theory $(N=1)$, Dittmar's (1992) Model on the Meaning of Material Possessions $(N=1)$, and Frey's (1988) Ipsative Theory of Behaviour $(N=2,8.3 \%)$. Authors rarely used theories in combination $(N=3,12.5 \%)$, but more frequently extended the TPB $(N$ $=8,33.3 \%)$ and NAM $(N=2)$ by measuring additional cognitive mechanisms, predominantly habit $(N=4,16.7 \%)$ and personal norms $(N=2)$.

\section{Meta-analytic Results (Research Questions 4 and 5)}

Data were available from 35 studies for inclusion in the meta-analyses (see Supplementary File, Chapter 5 for further explanations and more detailed results). We performed metaanalysis separately for: (1) cognitive mechanisms associated with car use (i.e. frequency or intensity of car use), and (2) cognitive mechanisms associated with non-car-use (i.e., how much car use had been replaced by an alternative mode). Moderator analyses (research question 5) were conducted when there were at least two studies and three associations in the smallest of the comparison groups. Results of these analyses are included in Tables 1 and 2. Below we only highlight significant dissimilarities between moderator groups, based on comparisons of confidence interval overlap.

A low number of studies testing each cognitive mechanism only allowed to perform bias assessment for 22 (out of 53) meta-analyses, of which seven were significant. We could not find any evidence suggestive of publication bias for most of the TPB measures and habit measures. However, results of Egger's tests suggested that for Car Use Attitude there may be "missing studies".

\section{Cognitive mechanisms associated with car use}

Table 1 presents meta-analytic results for associations with car use $(N=27, k=87)$ for a total sample of 35,645. Car use was mainly operationalised as driving or using a private motorised 
vehicle but occasionally included taxi journeys (Gardner \& Abraham, 2010), taxi and

motorcycle use (Verplanken et al., 2008), or car share and rental cars (Hunecke, Haustein,

Grischkat, \& Bohler, 2007). One study specified car use as single occupancy driving (Golob

\& Hensher, 1998).

Table 1. Results of the meta-analysis of car use

\begin{tabular}{|c|c|c|c|c|c|c|}
\hline Cognitive mechanism (sub-groups) & $n$ & $k$ & $r+$ & $95 \% \mathrm{CI}$ & $I^{2}(\%)$ & Egger's test \\
\hline Car Use Attitudes & 4647 & 38 & $0.22 * * *$ & $0.13,0.30$ & 91.6 & $6.8(p=0.01)$ \\
\hline non-urban & 3186 & 29 & $0.14 * * *$ & $0.06,0.23$ & 87.2 & $8.8(p=0.07)$ \\
\hline urban & 1461 & 9 & $0.31 * * *$ & $0.21,0.41$ & 83.2 & $3.6(p=0.17)$ \\
\hline non-commuting journeys & 3019 & 24 & $0.15^{* *}$ & $0.05,0.25$ & 92.4 & $9.4(p=0.12)$ \\
\hline commuting journeys & 1628 & 14 & $0.34 * * *$ & $0.26,0.42$ & 78 & $4.2(p=0.11)$ \\
\hline non-European & 927 & 3 & $0.37 * * *$ & $0.26,0.48$ & 83.9 & $7.8(p=0.10)$ \\
\hline European & 3720 & 35 & $0.18^{* * *}$ & $0.09,0.27$ & 90.8 & $6.3(p=0.04)$ \\
\hline typical car use & 4218 & 28 & $0.21 * * *$ & $0.12,0.30$ & 92.3 & $6.5(p=0.01)$ \\
\hline actual car use & 429 & 10 & $0.28 *$ & $0.06,0.50$ & 92 & - \\
\hline TPB measures & 1290 & 6 & $0.33 * * *$ & $0.20,0.46$ & 89.3 & $2.8(p=0.62)$ \\
\hline Beliefs & 3586 & 32 & $0.19 * * *$ & $0.09,0.29$ & 92.2 & $9.2(p=0.01)$ \\
\hline Non-car-use Attitudes & 812 & 3 & $-0.23 * *$ & $-0.40,-0.06$ & 90.7 & - \\
\hline Attitudes - Travel in General & 1486 & 10 & 0.05 & $-0.05,0.15$ & 84.6 & - \\
\hline Attitudes - Environment \& Health & 4097 & 9 & $-0.10 * *$ & $-0.17,-0.03$ & 86.2 & - \\
\hline non-urban & 2804 & 3 & -0.09 & $-0.18,0.00$ & 89 & - \\
\hline urban & 1293 & 6 & $-0.13 *$ & $-0.25,0.00$ & 87.4 & - \\
\hline Attitudes - Transport Environment & 4811 & 12 & $-0.28 * * *$ & $-0.41,-0.15$ & 97.5 & - \\
\hline non-urban & 1759 & 8 & $-0.17 * * *$ & $-0.23,-0.11$ & 70.5 & - \\
\hline urban & 3052 & 4 & $-0.35 * * *$ & $-0.52,-0.17$ & 98.6 & - \\
\hline Car Use Subjective Norms & 1455 & 6 & $0.20 * *$ & $0.05,0.35$ & 91.3 & $12.2(p=0.20)$ \\
\hline \begin{tabular}{|l} 
Non-car-use Subjective Norms \\
\end{tabular} & 944 & 3 & $-0.15 * * *$ & $-0.20,-0.11$ & $\mathbf{0}$ & - \\
\hline Car Use Descriptive Norms & 532 & 3 & -0.07 & $-0.35,0.21$ & 94.2 & - \\
\hline Car Use PBC & 1605 & 9 & $0.39 * * *$ & $0.18,0.60$ & 97.1 & $-6.3(p=0.75)$ \\
\hline Non-car-use PBC & 1200 & 5 & $-0.42 * * *$ & $-0.57,-0.28$ & 93 & - \\
\hline PBC - Environment & 324 & 4 & $-0.08 * *$ & $-0.17,-0.05$ & 52.8 & - \\
\hline Car Use Intentions & 2375 & 7 & $0.50 * * *$ & $0.31,0.68$ & 98.3 & $8.3(p=0.33)$ \\
\hline non-urban & 844 & 3 & 0.34 & $-0.04,0.71$ & 99.2 & - \\
\hline urban & 1531 & 4 & $0.59 * * *$ & $0.47,0.70$ & 95.6 & $9.1(p=0.01)$ \\
\hline non-commuting $\mathrm{j}$ & 1438 & 3 & $0.50 * * *$ & $0.33,0.67$ & 96.7 & - \\
\hline urneys & 937 & 4 & $0.50^{* *}$ & $0.15,0.85$ & 98.9 & $26.4(p=0.24)$ \\
\hline typical car use & 1839 & 4 & $0.47 * * *$ & $0.26,0.67$ & 97.9 & $6.2(p=0.62)$ \\
\hline actual car use & 536 & 3 & $0.62 * * *$ & $0.25,0.98$ & 98.7 & - \\
\hline
\end{tabular}

URL: http://mc.manuscriptcentral.com/ttrv 


\begin{tabular}{|c|c|c|c|c|c|c|}
\hline Cognitive mechanism (sub-groups) & $n$ & $k$ & $r+$ & $95 \% \mathrm{CI}$ & $I^{2}(\%)$ & Egger's test \\
\hline Non-car-use Intentions & 943 & 3 & $-0.38 *$ & $-0.68,-0.09$ & 98.1 & - \\
\hline Non-car-use Personal Norms & 793 & 5 & $-0.35 * * *$ & $-0.42,-0.28$ & 69.3 & - \\
\hline Ascription of Responsibilities & 642 & 3 & -0.14 & $-0.31,0.03$ & 87.7 & - \\
\hline Awareness of Consequences & 2139 & 6 & $-0.22 * * *$ & $-0.29,-0.16$ & 69.1 & - \\
\hline Altruistic Value Orientation & 184 & 3 & $-0.32 * * *$ & $-0.34,-0.29$ & $\mathbf{0}$ & - \\
\hline Identity Anti-Car & 1609 & 11 & $-0.08 * *$ & $-0.11,-0.02$ & 39.1 & - \\
\hline Identity Pro-Car & 4229 & 11 & $0.05 * * *$ & $0.04,0.07$ & $\mathbf{0}$ & - \\
\hline Social Comparison & 1247 & 6 & $0.16 * *$ & $0.06,0.26$ & 84.5 & - \\
\hline Car Use Habit - RFM & 2058 & 6 & $0.47 * * *$ & $0.39,0.56$ & 89 & $2.7(p=0.42)$ \\
\hline typical car use & 445 & 3 & $0.53 * * *$ & $0.39,0.66$ & 87.9 & - \\
\hline actual car use & 1613 & 3 & $0.46 * * *$ & $0.35,0.57$ & 92.1 & - \\
\hline Car Use Habit - Other Measures & 2160 & 7 & $0.38 * * *$ & $0.20,0.56$ & 97.8 & $7(p=0.48)$ \\
\hline past behaviour & 1248 & 2 & $0.58 * * *$ & $0.37,0.78$ & 97.7 & - \\
\hline SRHI & 523 & 2 & 0.28 & $-0.08,0.64$ & 98.6 & - \\
\hline latent variable & 1437 & 2 & $0.49 * * *$ & $0.29,0.69$ & 98.6 & - \\
\hline
\end{tabular}

Car use Attitudes were the most studied cognitive mechanism with 38 associations tested.

The meta-analysis suggested that the relationship between (positive) attitudes and car use was positive, and of a small to medium size $\left(r_{+}=.22\right.$, CI: $\left.0.13 ; 0.30\right)$. There was considerable heterogeneity across studies $\left(I^{2}=91.6 \%\right)$.

Moderator analysis, to explore this heterogeneity further, showed that the link between attitudes and car use was stronger for commuting journeys $\left(r_{+}=.34\right.$, CI: $0.26 ; 0.42, k$ $\left.=14, I^{2}=78 \%\right)$ than for non-commuting journeys $\left(r_{+}=.15\right.$, CI: $0.05 ; 0.25, k=24, I^{2}=$ 92.4\%). Attitudinal scales using TPB measures were relatively stronger predictors $\left(r_{+}=.33\right.$, CI: $0.20 ; 0.46, k=6, I^{2}=89.3 \%$ ) while those employing car use beliefs showed smaller effects $\left(r_{+}=.19\right.$, CI :0.09;0.29, $\left.k=32, I^{2}=92.2 \%\right)$.

Non-car-use Attitudes. Favourable attitudes towards alternative transport modes were negatively associated with car use $\left(r_{+}=-.23\right.$, CI: $\left.-0.40 ;-0.06, k=3, I^{2}=90.7 \%\right)$. Despite 
continued heterogeneity, moderator analysis was not performed due to a limited number of associations.

Attitudes - Travel in General. The relationship general evaluations about travel and car use was not significant $\left(r_{+}=.05\right.$, CI: $\left.-0.05 ; 0.15, k=10, I^{2}=84.6 \%\right)$. The result was underpinned by only three studies of varying effect sizes. Attitudinal measures varied, assessing the subjective importance of flexibility or time (Joireman, Van Lange, Kuhlman, Van Vugt, \& Shelley, 1997; Van Vugt, Meertens, \& Van Lange, 1995), stress (Cao \& Mokhtarian, 2005) or comfort (Joireman et al., 1997). Inconsistent operationalisations may have created this variability.

Attitudes - Environment \& Health. Drivers' concern about environmental protection and public health showed small negative associations with car use $\left(r_{+}=-.10, \mathrm{CI}:-0.17 ;-0.03, k=\right.$ $\left.9, I^{2}=86.2\right)$.

Attitudes - Transport Environment. Positive perceptions of the built environment such as proximity to shops (Scheiner \& Holz-Rau, 2007), walkability or cyclability (Panter et al., 2013) or concerns about traffic congestion (Golob \& Hensher, 1998) were also negatively associated with car use $\left(r_{+}=-.28, \mathrm{CI}:-0.41 ;-0.15, k=12, I^{2}=97.5 \%\right)$.

Car Use Subjective Norms. A small to medium-sized positive association was observed between driving and drivers' perceptions of others' approval of driving $\left(r_{+}=.20, \mathrm{CI}\right.$ : $0.05 ; 0.35, k=6$ ). Effect sizes varied considerably across studies (range from $r=.03$ to $r=$ $\left..52, I^{2}=91.3 \%\right)$ with half of the studies including subjective norm measures $(N=3)$ reported non-significant associations with car use. 
Non-car-use Subjective Norms. Combining effect sizes from three studies generated a small negative, homogeneous average association $\left(r_{+}=-.15\right.$, CI: $\left.-0.20 ;-0.11, I^{2}=0 \%\right)$.

Car Use Descriptive Norms. Although there was a small negative relationship between selfreported car use and perceptions about other people's car use behaviour, this was not significant $\left(r_{+}=-.07, \mathrm{CI}:-0.35 ; 0.21, I^{2}=94.2 \%\right)$.

Car use PBC. Control beliefs (e.g. freedom or confidence) were positively associated with car use $\left(r_{+}=.30, p=.021, k=10\right)$ and this was increased $\left(r_{+}=.39, \mathrm{CI}: 0.18 ; 0.60, k=9\right)$ when an anomalous negative association (Gardner \& Abraham, 2010, $r_{+}=-.33$ ) was removed from further analysis. Heterogeneity was again high $\left(I^{2}=97.1 \%\right)$ reflecting the combination of measures of feasibility, (Verplanken, Aarts, van Knippenberg, \& Moonen, 1998), confidence, (Panter et al., 2013) and perceptions of parking problems and accident risks (Mann \& Abraham, 2012).

Non-car-use PBC. A negative heterogeneous association was observed between perceived difficulty of driving and car use ( $\left.r_{+}=-.42, \mathrm{CI}:-0.57 ;-0.28, k=5, I^{2}=93 \%\right)$.

$P B C$ - Environment. People's beliefs about the capability of reducing environmental damage showed a very small negative, though relatively homogenous, negative association with car use $\left(r_{+}=-.08, \mathrm{CI}:-0.17 ;-0.05, k=4, I^{2}=52.8 \%\right)$.

Car Use Intentions showed a large, positive, heterogeneous association with car use $\left(r_{+}=.50\right.$, CI: $\left.0.31 ; 0.68, k=7, I^{2}=98.3 \%\right)$. See Supplementary File, Chapter 5.1 for further details about effect size variability. 
Non-car-use Intentions produced a weaker, negative, heterogeneous association with car use $\left(r_{+}=-.38, \mathrm{CI}:-0.68 ;-0.09, k=3, I^{2}=98.1 \%\right)$.

Non-car-use Personal Norms. Feeling a moral obligation not to drive had a negative medium association with car use $\left(r_{+}=-.35, \mathrm{CI}:-0.42 ;-0.28\right)$. This result was underpinned by five studies with substantial heterogeneity $\left(I^{2}=69.3 \%\right)$.

Awareness of Consequences. Combining effect sizes generated a small to medium negative effect $\left(r_{+}=-.22\right.$, CI: $\left.-0.22 ;-0.16, k=6, I^{2}=69.1 \%\right)$, such that people who were more aware of the environmental consequences of car use, also reported driving less frequently. See Supplementary File, Chapter 5.2 for for further details about effect size variability.

Ascription of Responsibilities. The relationship between car use and the perceived responsibility to reduce environmental impacts was negative but not significant $\left(r_{+}=-.14, \mathrm{CI}\right.$ : $\left.-0.31 ; 0.03, k=3, I^{2}=87.7 \%\right)$.

Altruistic Value Orientation. Consistent with theory, there was a negative, moderate association between altruistic values and car use $\left(r_{+}=-.32\right.$, CI: $\left.-0.34 ;-0.29, k=3\right)$. Metaanalysis was performed on two homogeneous studies $\left(I^{2}=0 \%\right)$.

Identity. A very small, negative association was observed between car use and anti-car identity measures $\left(r_{+}=-.08, \mathrm{CI}:-0.11 ;-0.02, k=11\right)$, while a very small positive association was observed between car use and pro-car identities $\left(r_{+}=.05\right.$, CI: $\left.0.04 ; 0.07, k=11\right)$. Both effects were homogeneous $\left(I^{2}=39.1 \%\right.$ and $I^{2}=0 \%$, respectively). 
Social Comparison. A small positive effect of $r_{+}=.16$ (CI: $\left.0.06 ; 0.26, k=6, I^{2}=84.5 \%\right)$ showed that people who consider driving as a means of self-evaluation and self-enhancement are also more likely to use the car.

Car Use Habit - RFM. Verplanken et al.'s (1994) Response Frequency Measure of habit was employed by six studies (a tool to assess habit strength of travel mode choices across different travel situations, drawing on automaticity component of habit). Meta-analysis suggested that car use was positively, associated with strong car use habits, though the effect was considerably heterogeneous $\left(r_{+}=.47\right.$, CI: 0.39;0.56, $\left.k=6, I^{2}=89 \%\right)$.

Car Use Habit - Other Measures. Five studies reported a total of seven associations that used other measures of car use habit based on different conceptualisations of habit (see Supplementary File, Chapter 5.3). Meta-analysis produced a medium to large, positive heterogeneous, effect of $r_{+}=.38$ (CI: $0.20 ; 0.56, \mathrm{k}=7, I^{2}=97.8 \%$ ). Moderator analyses for the different conceptualisations of habit identified the largest effect for "past behaviour" $\left(r_{+}=\right.$ .58 , CI: $\left.0.37 ; 0.78, k=2, I^{2}=97.7 \%\right)$. Whilst generating the largest effect size, this result was based on only two studies.

\section{Cognitive mechanisms of non-car-use}

Table 2 presents results for the meta-analysis of non-car-use studies with an overall sample size of $n=12,335$. Only nine studies were available for inclusion, so few moderator analyses could be undertaken. Moreover, these studies used varying operationalisations of alternatives to car use. Specifically, (1) use of other forms of transport in general (Harland et al., 1999), (2) use of PT (Bamberg, 2006; Yang-Wallentin, Schmidt, Davidov, \& Bamberg, 2004), (3) use of environmentally friendly transport modes (incl. walking, cycling, bus, tram/subway, regional train, long-distance train) (Haustein \& Hunecke, 2007) and (4) use of the subway 
instead of the car (Hunecke, Blöbaum, Matthies, \& Hoeger, 2001). Aggregating these operationalisations is not ideal and high levels of heterogeneity suggests caution in interpretation.

Table 2. Results of the meta-analysis of non-car-use

\begin{tabular}{|l|l|l|l|l|l|l|}
\hline Cognitive mechanism (sub-groups) & $n$ & $k$ & $r+$ & $95 \%$ CI & $I^{2}(\%)$ & Egger's test \\
\hline Non-car-use Attitudes & $\mathbf{2 5 9 7}$ & $\mathbf{7}$ & $\mathbf{0 . 3 6} * * *$ & $\mathbf{0 . 2 1 , 0 . 5 1}$ & $\mathbf{9 7 . 1}$ & $\mathbf{1 1 . 3}(\boldsymbol{p}=\mathbf{0 . 1 9})$ \\
\hline Non-car-use Subjective Norms & $\mathbf{2 7 4 5}$ & $\mathbf{6}$ & $\mathbf{0 . 2 8} * * *$ & $\mathbf{0 . 1 4 , 0 . 4 1}$ & $\mathbf{9 5 . 6}$ & $\mathbf{5 . 1}(\boldsymbol{p}=\mathbf{0 . 4 1})$ \\
\hline Non-car-use PBC & $\mathbf{3 5 0 0}$ & $\mathbf{9}$ & $\mathbf{0 . 4 9} * * *$ & $\mathbf{0 . 4 1 , 0 . 5 7}$ & $\mathbf{9 3 . 9}$ & $\mathbf{8 . 3}(\boldsymbol{p}=\mathbf{0 . 1 4})$ \\
\hline typical non-car-use & 2347 & 4 & $0.49 * * *$ & $0.39,0.59$ & 93.3 & - \\
actual non-car-use & 1153 & 3 & $0.50^{* * *}$ & $0.34,0.66$ & 97.2 & - \\
\hline Non-car-use Intentions & $\mathbf{3 4 9 3}$ & $\mathbf{8}$ & $\mathbf{0 . 4 8} * * *$ & $\mathbf{0 . 3 5 , 0 . 6 1}$ & $\mathbf{9 7 . 3}$ & $\mathbf{1 1 . 8}(\boldsymbol{p}=\mathbf{0 . 1 8})$ \\
\hline$* p<.05, * * p<.01, * * * p<.001$ & & & & & & \\
\hline
\end{tabular}

Non-car-use Attitudes. Positive attitudes towards alternative travel modes was associated with a medium-level, though heterogeneous, positive relationship with non-car-use $\left(r_{+}=.36\right.$, CI: $\left.0.21 ; 0.51, k=7, I^{2}=97.1 \%\right)$.

Non-car-use Subjective Norms. Non-car-use was positively associated with stronger subjective norms towards not driving, though the effect was small to medium and heterogeneous $\left(r_{+}=.28\right.$, CI: $\left.0.14 ; 0.41, k=6, I^{2}=95.6 \%\right)$.

Non-car-use PBC. A large, positive effect between the perceived ease of using alternative travel modes and the reported use of alternatives to the car $\left(r_{+}=.49, \mathrm{CI}: 0.41 ; 0.57, k=9\right)$ was considerably heterogeneous $\left(I^{2}=93.9 \%\right)$.

Non-car-use Intentions. A large, positive association between non-car-use and the intention not to drive was observed, though yielded a heterogeneous effect $\left(r_{+}=.48, \mathrm{CI}: 0.35 ; 0.61, k=\right.$ $\left.8, I^{2}=97.3 \%\right)$ 


\section{Discussion}

This systematic review of 25 years of research into measures of potentially-modifiable cognitive mechanisms associated with transport mode choice identified 43 relevant studies of which 35 generated data that could be included in meta-analyses. The mechanisms assessed in these studies could be grouped into 22 conceptually-coherent categories of cognitive mechanisms related to car use and 4 categories of cognitive mechanisms related to non-caruse. Our results support and extend those of previous reviews, in particular Gardner and Abraham (2008), who summarised results from 23 studies identifying 18 unique potentiallymodifiable correlates of car use and car use intentions.

Included studies were assessed to be of low to moderate methodological quality. Few studies conducted an a priori power analyses (Cohen, 2013) and few samples could be regarded as representative of particular populations of drivers. In many instances study quality indicators received low scores because important information for assessing quality was not reported. In part, this reflects the multi-disciplinary roots of the field, where reporting standards may vary. We also acknowledge that many studies were conducted before it was common practice to include supplementary materials in digital format. We would therefore urge future researchers in this field to provide comprehensive methodological details in supplementary materials, to aid future reviews. Further work could also validate a quality assessment tool, suitable for cross-sectional studies or systematic reviews with mixed study design. In addition, the range of cognitive mechanisms assessed strongly suggests that use of standardised measures would facilitate data syntheses in this field. In particular, development of validated self-report measures of the extent of car use and use of alternative transportation modes to replace car use could accelerate progress in identifying intervention targets. In achieving coherence of measurements we suggest adopting items recommended by Ajzen or 
Francis et al. (2004) and encourage the use of already published measures that were identified in this review.

Our findings identify a clear pattern. Two theories, the Theory of Planned Behaviour (TPB) and the Norm Activation Model (NAM) were widely applied and results support continued use of the TPB but offer less support for NAM because, measures of PBC, intentions and habit generated consistently higher average effect sizes than measures of norms. This does not mean that normative beliefs are inconsequential but that unless higher activation levels can be reached, they may not be the most effective change targets for interventions seeking to reduce car use. Interestingly too, TPB-derived attitude measures generated somewhat higher average effect sizes than other attitudinal measures. Attitudinal measures incorporating affective components showed the weakest individual effect sizes in both categories of non-car-use attitudes (Armitage, Reid, \& Spencer, 2013; Haustein \& Hunecke, 2007).

The range of attitude and car use/ non-car-use-measures emphasises that the importance of attitudes critically depends on what type of car use/ car use reduction is being predicted. For example, attitudes may be better predictors of urban and commuting journeys than of other journey types. Thus targeting reductions in particular types of car journey may be more effective than planning reductions in driving per se (Graham-Rowe et al., 2011). While our results generally support the important role often assigned to attitudes (e.g., Boarnet \& Crane, 2001; Fujii \& Gärling, 2003; Sunkanapalli, Pendyala, \& Kuppam, 2000), they also advocate greater specificity of cognition measures.

People can evaluate transport mode choices as both positive and negative depending on the journey type and the transport environment. For example, cycling may be viewed as good exercise (attitudes - environment and health) but also impractical when faced with high volumes of traffic (attitudes - transport environment). It is notable too, that drivers' 
environmental and health-related attitudes did not have strong associations with car use.

Hence, clarification of the complex structure of attitudes in measurement methods could clarify intervention targets.

It is unsurprising to note that people's perceived feasibility of alternatives and confidence in being able to use these alternatives is important to driving reduction (see noncar-use PBC) (Klöckner \& Friedrichsmeier, 2011). Constraints may be imposed by job or family responsibilities or by infrastructure limitations. Acknowledging this, Haustein and Hunecke (2007) have defined a measure of perceived mobility necessities. Klöckner and Blöbaum (2010) included perceived mobility necessities items in their perceived behavioural control measure and this study yielded the largest individual effect size $(r=.72)$ between a measure of a potentially-modifiable cognition and reported car use, suggesting that perceived mobility necessities may well be an important adjunct to controllability measures.

Meta-analyses of intentions and habits supported previous findings (Gardner \& Abraham, 2008) emphasizing both the importance of intentions not to drive and the challenges of translating such motivation into action by those who habitually and perhaps unthinkingly drive to travel (Gardner, 2009). Identifying interventions capable of breaking habits may, therefore, be as important as employing persuasive interventions targeting motivation. For instance, a series of studies by Verplanken and colleagues (Verplanken \& Roy, 2015; Verplanken et al., 2008; Walker, Thomas, \& Verplanken, 2015) into the habit discontinuity hypothesis have demonstrated how contextual changes, e.g. moving home or offices, can weaken habits. Likewise, the formation of if-then plans or implementation intentions to change travel mode amongst a sample with strong car use habits has proven to be effective in a driving reduction experiment (Eriksson, Garvill, \& Nordlund, 2008).

We were disappointed that so few moderator analyses could be conducted. Insufficient reporting and aggregation of journey types and location limited our ability to 
draw conclusions about possible change targets in different contexts. Hence, moderator analysis remains exploratory in this review. Variations between study findings may be explained by factors not investigated in this review (e.g. other confounders or the use of different measurement scales for cognitive mechanisms). Journeys may also be helpfully categorised by length (Harland et al., 1999) as mode choice behaviour changes with varying travel distance (Sustrans, 2014). Both purpose and length may moderate changeability and possible key change mechanisms. The review also highlighted that geographical journey location categories need careful specification. For example, rural as opposed to urban journeys may - or may not - indicate poorer PT accessibility (Mann \& Abraham, 2012). PT accessibility as well as walkability and cyclability may be critical to behaviour change and indexes such as the Transport for London's Public Transport Accessibility measures may be helpful in this regard (Chng, White, Abraham, Alcock \& Skippon, under review).

\section{Study limitations}

Due to the inconsistent methodological quality and heterogeneity of the primary studies, the current review was unable to provide clear and unambiguous findings. Variations in individual effect sizes are considerable due, no doubt, in part to the wide range of different measures used across studies. Thus, we acknowledge that interpretation of our findings should be cautious because we include similar but not identical measures of cognitive mechanisms across samples. Also, as with other meta-analytic reviews of this literature (e.g. Gardner \& Abraham, 2008; Neoh, Chipulu, \& Marshall, 2015), the number of included studies for moderator analyses was sometimes very small. This limits our ability to draw meaningful conclusions and generalise across populations.

The data we have summarised is correlational, more detailed analyses of carefully designed controlled intervention studies would provide a more definitive and causal guide to 
which cognitive mechanisms can and cannot be easily changed in which populations and what impact this has on which journey types in specified contexts. Unfortunately, current intervention evaluations do not permit such analyses (Arnott et al., 2014; Graham-Rowe et al., 2011). Likewise, the analyses of bivariate relationships as investigated in this review do not identify inverse associations, e.g. a person's attitudes or PBC might be a result of that person's choice of transport rather than a determinant thereof.

The quality assessment sought to detect potential confounders by applying core criteria common across all studies in this review. However, this does not exclude the possibility of other confounding variables (e.g. walkability, access to a car or accessibility of PT) which vary across studies and time.

\section{Conclusion}

The current systematic review summarises the evidence of associations between specific cognitive mechanisms and both, car use and non-car-use. The review highlights the wide range of such mechanisms and the limited number of theories used to conceptualise these. In particular, the use of theories other than rational choice models could advance our understanding of the motivation (not) to drive. Our meta-analyses show that the strongest correlates of car use and non-car-use were intentions, perceived behavioural control and attitudes with habit also being a strong predictor of car use. Development of standardised measures, both of change mechanisms and of driving and use of alternative transport modes could help accelerate identification of optimal change targets. Most importantly, heterogeneity of attitudinal measurement needs urgent attention and we propose greater specificity and consensus of measures. Careful categorisation of journey type and length as well as descriptions of the geographical setting could also facilitate intervention design. We recommend that a consensual, validated quality assessment tool is developed for cross- 
28

sectional studies, to be used by both primary researchers and reviewers. We considered methodological criteria identified across six such tools and found that study quality was moderate to weak. Finally, we suggest that researchers make extensive use of supplementary materials to clarify study methodology. 


\section{References}

Aarts, H., \& Dijksterhuis, A. (2000). The automatic activation of goal-directed behaviour: The case of travel habit. Journal of Environmental Psychology, 20(1), 75-82. http://doi.org/10.1006/jevp.1999.0156

**Abrahamse, W., Steg, L., Gifford, R., \& Vlek, C. (2009). Factors influencing car use for commuting and the intention to reduce it: A question of self-interest or morality? Transportation Research Part F: Traffic Psychology and Behaviour, 12(4), 317-324

Ajzen, I. (1991). The theory of planned behavior. Organizational behavior and human decision processes, 50(2), 179-211.

**Armitage, C. J., Reid, J. C., \& Spencer, C. P. (2013). Changes in cognition and behaviour: a causal analysis of single-occupancy car use in a rural community. Transportmetrica a-Transport Science, 9(1), 1-10. doi: 10.1080/18128602.2010.509706

Arnott, B., Rehackova, L., Errington, L., Sniehotta, F. F., Roberts, J. R., \& Araujo-Soares, V. (2014). Efficacy of behavioural interventions for transport behaviour change: systematic review, meta-analysis and intervention coding. International journal of behavioral nutrition and physical activity, 11(1), 133

*Baldassare, M. (1991). Transportation in suburbia - trends in attitudes, behaviors and policy preferences in orange county, california. Transportation, 18(3), 207-222

**Bamberg, S. (2006). Is a residential relocation a good opportunity to change people's travel behavior? Results from a theory-driven intervention study. Environment and Behavior, 38(6), 820-840. doi: 10.1177/0013916505285091

*Bamberg, S., Ajzen, I., \& Schmidt, P. (2003). Choice of travel mode in the theory of planned behavior: The roles of past behavior, habit, and reasoned action. Basic and Applied Social Psychology, 25(3), 175-187. doi: 10.1207/s15324834basp2503_01

Bamberg, S., Fujii, S., Friman, M., \& Gärling, T. (2011). Behaviour theory and soft transport policy measures. Transport Policy, 18(1), 228-235. doi: http://dx.doi.org/10.1016/j.tranpol.2010.08.006

*Bamberg, S., \& Schmidt, P. (2003). Incentives, morality, or habit? Predicting students' car use for university routes with the models of Ajzen, Schwartz, and Triandis. Environment and Behavior, 35(2), 264-285. doi: 10.1177/0013916502250134

Begg, C. B., \& Mazumdar, M. (1994). Operating characteristics of a rank correlation test for publication bias. Biometrics, 1088-1101 
**Bergstad, C. J., Gamble, A., Hagman, O., Polk, M., Garling, T., \& Olsson, L. E. (2011). Affective-symbolic and instrumental-independence psychological motives mediating effects of socio-demographic variables on daily car use. Journal of Transport Geography, 19(1), 33-38. doi: 10.1016/j.jtrangeo.2009.11.006

Borenstein, M., Hedges, L. V., Higgins, J. P. T., \& Rothstein, H. R. (2009). Introduction to Meta-Analysis: Wiley.

Cairns, S., Sloman, L., Newson, C., Anable, J., Kirkbride, A., \& Goodwin, P. (2008). Smarter Choices: Assessing the Potential to Achieve Traffic Reduction Using Soft Measures. Transport Reviews, 28(5), pp 593-618

**Cao, X., \& Mokhtarian, P. L. (2005). How do individuals adapt their personal travel? Objective and subjective influences on the consideration of travel-related strategies for San Francisco Bay Area commuters. Transport Policy, 12(4), 291-302

Chng, S., White, M., Abraham, C., Alcock, I., \& Skippon, S. (Under review). Commuting in England and Wales: The role of urban density, travel distance and public transport accessibility. Transportation Research Part D: Transport and Environment.

Cohen, J. (1988). Statistical Power Analysis for the Behavioral Sciences. 2nd edn. Hillsdale, New Jersey.

Cohen, J. (2013). Statistical power analysis for the behavioral sciences: Routledge Academic. Statistical power analysis for the behavioral sciences. Routledge Academic.

*Collins, C. M., \& Chambers, S. M. (2005). Psychological and situational influences on commuter-transport-mode choice. Environment and Behavior, 37(5), 640-661. doi: $10.1177 / 0013916504265440$

**Davidov, E. (2007). Explaining habits in a new context - The case of travel-mode choice. Rationality and Society, 19(3), 315-334. doi: 10.1177/1043463107077392

De Witte, A., Hollevoet, J., Dobruszkes, F., Hubert, M., \& Macharis, C. (2013). Linking modal choice to motility: A comprehensive review. Transportation Research Part A: Policy and Practice, 49, 329-341.

Dittmar, H. (1992). The social psychology of material possessions: To have is to be: Harvester Wheatsheaf Hemel Hempstead.

Dunlap, R. E., \& Van Liere, K. D. (1978). The “new environmental paradigm”. The journal of environmental education, 9(4), 10-19. 
Effective Public Health Practice Project (EPHPP). (1998). Quality Assessment Tool For Quantitative Studies. Hamilton, ON: Effective Public Health Practice Project. Available from: http://www.ephpp.ca/index.html.

Egger, M., Smith, G. D., Schneider, M., \& Minder, C. (1997). Bias in meta-analysis detected by a simple, graphical test. Bmj, 315(7109), 629-634

Eriksson, L., Garvill, J., \& Nordlund, A. M. (2008). Interrupting habitual car use: The importance of car habit strength and moral motivation for personal car use reduction. Transportation Research Part F: Traffic Psychology and Behaviour, 11(1), 10-23. doi: http://dx.doi.org/10.1016/j.trf.2007.05.004

Fishbein, M., \& Ajzen, I. (1975). Belief, Attitude, Intention, and Behavior: An Introduction to Theory and Research. Reading, MA: Addison-Wesley.

Francis, J. J., Eccles, M. P., Johnston, M., Walker, A., Grimshaw, J., Foy, R., ... \& Bonetti, D. (2004). Constructing questionnaires based on the theory of planned behaviour. $A$ manual for health services researchers, 2010, 2-12.

Frank, L. D. (2004). Economic determinants of urban form - Resulting trade-offs between active and sedentary forms of travel. American Journal of Preventive Medicine, 27(3), 146-153. doi: 10.1016/j.amepre.2004.06.018

Frank, L., Bradley, M., Kavage, S., Chapman, J., \& Lawton, T. K. (2008). Urban form, travel time, and cost relationships with tour complexity and mode choice. Transportation, 35(1), 37-54.

Frey, B. S. (1988). Ein ipsatives Modell menschlichen Verhaltens. Ein Beitrag zur Ökonomie und Psychologie. Analyse und Kritik, 10(2), 181

**Friedrichsmeier, T., Matthies, E., \& Klöckner, C. A. (2013). Explaining stability in travel mode choice: An empirical comparison of two concepts of habit. Transportation Research Part F: Traffic Psychology and Behaviour, 16, pp 1-13

Fujii, S., Gärling, T., \& Kitamura, R. (2001). Changes in Drivers' Perceptions and Use of Public Transport during a Freeway Closure Effects of Temporary Structural Change on Cooperation in a Real-Life Social Dilemma. Environment and Behavior, 33(6), 796-808

**Gardner, B. (2009). Modelling motivation and habit in stable travel mode contexts. Transportation Research Part F: Traffic Psychology and Behaviour, 12(1), 68-76. doi: 10.1016/j.trf.2008.08.001 
Gardner, B., \& Abraham, C. (2008). Psychological correlates of car use: A meta-analysis. Transportation Research Part F-Traffic Psychology and Behaviour, 11(4), 300-311. doi: 10.1016/j.trf.2008.01.004

**Gardner, B., \& Abraham, C. (2010). Going green? Modeling the impact of environmental concerns and perceptions of transportation alternatives on decisions to drive. Journal of Applied Social Psychology, 40(4), 831-849

Gärling, T., \& Axhausen, K. W. (2003). Introduction: Habitual travel choice. Transportation, $30(1), 1-11$.

**Gärling, T., Fujii, S., \& Boe, O. (2001). Empirical tests of a model of determinants of script-based driving choice. Transportation Research Part F: Traffic Psychology and Behaviour, 4(2), 89-102. doi:http://dx.doi.org/10.1016/S1369-8478(01)00016-X

Garver, M. S., \& Mentzer, J. T. (1999). Logistics research methods: employing structural equation modeling to test for construct validity. Journal of Business Logistics, 20, 3358

Gautheir, B. (2001, April). Assessing survey research: a principled approach (work-inprogress report). In Proceedings of the Professional Marketing Research Society Annual Conference. Ottawa, Ontario, Canada (pp. 1-28).

Gliem, J. A., \& Gliem, R. R. (2003). Calculating, interpreting, and reporting Cronbach's alpha reliability coefficient for Likert-type scales: Midwest Research-to-Practice Conference in Adult, Continuing, and Community Education.

**Golob, T. F., \& Hensher, D. A. (1998). Greenhouse gas emissions and Australian commuters' attitudes and behavior concerning abatement policies and personal involvement. Transportation Research Part D-Transport and Environment, 3(1), 118. doi: 10.1016/s1361-9209(97)00006-0

Graham-Rowe, E., Skippon, S., Gardner, B., \& Abraham, C. (2011). Can we reduce car use and, if so, how? A review of available evidence. Transportation Research Part A: Policy and Practice, 45(5), 401-418. doi: http://dx.doi.org/10.1016/j.tra.2011.02.001

Gwet, K. (2002). Kappa statistic is not satisfactory for assessing the extent of agreement between raters. Statistical methods for inter-rater reliability assessment, 1(6), 1-6

Hagger, M. S., Chatzisarantis, N. L., \& Biddle, S. J. (2002). A meta-analytic review of the theories of reasoned action and planned behavior in physical activity: Predictive validity and the contribution of additional variables. Journal of sport \& exercise psychology, 24(1). 
**Harland, P., Staats, H., \& Wilke, H. A. M. (1999). Explaining proenvironmental intention and behavior by personal norms and the theory of planned behavior1. Journal of applied social psychology, 29(12), 2505-2528

**Haustein, S., \& Hunecke, M. (2007). Reduced use of environmentally friendly modes of transportation caused by perceived mobility necessities: An extension of the theory of planned behavior. Journal of Applied Social Psychology, 37(8), 1856-1883. doi: 10.1111/j.1559-1816.2007.00241.x

Hoelter, J. W. (1983). The analysis of covariance structures goodness-of-fit indices. Sociological Methods \& Research, 11(3), 325-344

*Hunecke, M., Blöbaum, A., Matthies, E., \& Hoeger, R. (2001). Responsibility and Environment. Ecological Norm Orientation and External Factors in the Domain of Travel Mode Choice Behavior. Environment \& Behavior, 33(6), 830-852. doi: http://dx.doi.org/10.1177/00139160121973269

*Hunecke, M., Haustein, S., Grischkat, S., \& Bohler, S. (2007). Psychological, sociodemographic, and infrastructural factors as determinants of ecological impact caused by mobility behavior. Journal of Environmental Psychology, 27(4), 277-292. doi: 10.1016/j.jenvp.2007.08.001

International Energy Agency (IEA). (2015). Energy and Climate Change. Paris: I. E. Agency. Retrieved from https://www.iea.org/publications/freepublications/publication/WEO2015SpecialRepor tonEnergyandClimateChange.pdf.

**Joireman, J. A., Van Lange, P. A. M., Kuhlman, D. M., Van Vugt, M., \& Shelley, G. P. (1997). An interdependence analysis of commuting decisions. European Journal of Social Psychology, 27(4), 441-463. doi: 10.1002/(SICI)10990992(199707)27:4<441::AID-EJSP804>3.0.CO;2-S

**Kaiser, F. G., \& Gutscher, H. (2003). The Proposition of a General Version of the Theory of Planned Behavior: Predicting Ecological Behavior. Journal of Applied Social Psychology, 33(3), 586-603. doi: 10.1111/j.1559-1816.2003.tb01914.x

Kelley, H. H., \& Thibaut, J. W. (1978). Interpersonal relations: A theory of interdependence: Wiley New York.

**Kerr, A., Lennon, A., \& Watson, B. (2010). The Call of the Road: Factors Predicting Students' Car Travelling Intentions and Behaviour. Transportation: Planning, Policy, Research, Practice, 37(1), pp 1-13 
Khan, K. S., Ter Riet, G., Glanville, J., Sowden, A. J., \& Kleijnen, J. (2001). Undertaking systematic reviews of research on effectiveness: CRD's guidance for carrying out or commissioning reviews: NHS Centre for Reviews and Dissemination.

Kline, R. B. (2011). Principles and practice of structural equation modeling: Guilford press.

**Klöckner, C. A., \& Blöbaum, A. (2010). A comprehensive action determination model.

Toward a broader understanding of ecological behaviour using the example of travel mode choice. Journal of Environmental Psychology, 30(4), 574-586. doi:

10.1016/j.jenvp.2010.03.001

Klöckner, C. A., \& Friedrichsmeier, T. (2011). A multi-level approach to travel mode choice-How person characteristics and situation specific aspects determine car use in a student sample. Transportation Research Part F: Traffic Psychology and Behaviour, 14(4), 261-277

**Klöckner, C. A., \& Matthies, E. (2004). How habits interfere with norm-directed behaviour: A normative decision-making model for travel mode choice. Journal of Environmental Psychology, 24(3), 319-327. doi: 10.1016/j.jenvp.2004.08.004

Lois, D., \& Lopez-Saez, M. (2009). The relationship between instrumental, symbolic and affective factors as predictors of car use: A structural equation modeling approach. Transportation Research Part a-Policy and Practice, 43(9-10), 790-799. doi: 10.1016/j.tra.2009.07.008

Macmillan, A. K., Hosking, J., Connor, J. L., Bullen, C., \& Ameratunga, S. (2013). A Cochrane systematic review of the effectiveness of organisational travel plans: Improving the evidence base for transport decisions. Transport policy, 29, 249-256.

**Mann, E., \& Abraham, C. (2012). Identifying Beliefs and Cognitions Underpinning Commuters' Travel Mode Choices. Journal of Applied Social Psychology, 42(11), 2730-2757

**Matthies, E., Klöckner, C. A., \& Preissner, C. L. (2006). Applying a modified moral decision making model to change habitual car use: How can commitment be effective? Applied Psychology-an International Review-Psychologie Appliquee-Revue Internationale, 55(1), 91-106. doi: 10.1111/j.1464-0597.2006.00237.x

**Murtagh, N., Gatersleben, B., \& Uzzell, D. (2012). Multiple identities and travel mode choice for regular journeys. Transportation Research Part F: Traffic Psychology and Behaviour, 15(5), pp 514-524. 
National Heart, Lung, and Blood Institute (NHLBI). (2014). Quality assessment tool for observational cohort and cross-sectional studies. Bethesda, MD: National Institutes of Health.

Neoh, J. G., Chipulu, M., \& Marshall, A. (2015). What encourages people to carpool? An evaluation of factors with meta-analysis. Transportation, 1-25. http://doi.org/10.1007/s11116-015-9661-7

**Nilsson, M., \& Kuller, R. (2000). Travel behaviour and environmental concern. Transportation Research Part D-Transport and Environment, 5(3), 211-234. doi: 10.1016/s1361-9209(99)00034-6

Pace, R., Pluye, P., Bartlett, G., Macaulay, A. C., Salsberg, J., Jagosh, J., \& Seller, R. (2012). Testing the reliability and efficiency of the pilot Mixed Methods Appraisal Tool (MMAT) for systematic mixed studies review. International journal of nursing studies, 49(1), 47-53.

**Panter, J., Desousa, C., \& Ogilvie, D. (2013). Incorporating walking or cycling into car journeys to and from work: The role of individual, workplace and environmental characteristics. Preventive Medicine, 56(3-4), 211-217. doi:

10.1016/j.ypmed.2013.01.014

Park, S., Kang, J., \& Choi, K. (2014). Finding determinants of transit users' walking and biking access trips to the station: A pilot case study. Ksce Journal of Civil Engineering, 18(2), 651-658. doi: 10.1007/s12205-014-0073-6

**Polk, M. (2003). Are women potentially more accommodating than men to a sustainable transportation system in Sweden? Transportation Research Part D: Transport and Environment, 8(2), p. 75-95

Popay, J., Roberts, H., Sowden, A., Petticrew, M., Arai, L., Rodgers, M., . . \& Duffy, S. (2006). Guidance on the conduct of narrative synthesis in systematic reviews. $A$ product from the ESRC methods programme. Version, 1

Ram, Y., Nawijn, J., \& Peeters, P. M. (2013). Happiness and limits to sustainable tourism mobility: a new conceptual model. Journal of Sustainable Tourism, 21(7), 1017-1035. doi: 10.1080/09669582.2013.826233

Richter, J., Friman, M., \& Gärling, T. (2010). Review of implementations of soft transport policy measures. Transportation: Theory and application, 2(1)

Rosenthal, R. (1979). The file drawer problem and tolerance for null results. Psychological bulletin, 86(3), 638

Ryan, R. (2013). Cochrane Consumers and Communication Review Group reviews: 
Meta-analysis.

Sahlqvist, S., Song, Y. N., \& Ogilvie, D. (2012). Is active travel associated with greater physical activity? The contribution of commuting and non-commuting active travel to total physical activity in adults. Preventive Medicine, 55(3), 206-211. doi: 10.1016/j.ypmed.2012.06.028

**Scheiner, J., \& Holz-Rau, C. (2007). Travel mode choice: affected by objective or subjective determinants? Transportation, 34(4), 487-511

Schwartz, S. H. (1977). Normative influences on altruism. Advances in experimental social psychology, 10, 221-279.

Shapiro, R. J., Hassett, K. A., \& Arnold, F. S. (2002). Conserving energy and preserving the environment: The role of public transportation. American Public Transportation Association, 9.

Şimşekoğlu, Ö., Nordfjærn, T., \& Rundmo, T. (2015). The role of attitudes, transport priorities, and car use habit for travel mode use and intentions to use public transportation in an urban Norwegian public. Transport Policy, 42, 113-120.

Sniehotta, F. F., Presseau, J., \& Araújo-Soares, V. (2014). Time to retire the theory of planned behaviour. Health Psychology Review, 8(1), 1-7

**Steg, L. (2005). Car use: lust and must. Instrumental, symbolic and affective motives for car use. Transportation Research Part a-Policy and Practice, 39(2-3), 147-162. doi: 10.1016/j.tra.2004.07.001

**Steg, L., \& Sievers, I. (2000). Cultural theory and individual perceptions of environmental risks. Environment and Behavior, 32(2), 250-269

Strack, F., \& Deutsch, R. (2004). Reflective and impulsive determinants of social behavior. Personality and social psychology review, 8(3), 220-247.

Stryker, S. (1980). Identity theory: A social structural version: Menlo Park, CA: Benjamin Cummings Company.

Sustrans (2014) Short journeys, big savings [Online]. Available from: http://www.sustrans.org.uk/sites/default/files/images/files/publications/Short\%20jour neys\%20big\%20savings\%2023\%20AUG.pdf [Accessed: 09 October 2015]

**Tanner, C. (1999). Constraints on environmental behaviour. Journal of Environmental Psychology, 19(2), 145-157. doi: http://dx.doi.org/10.1006/jevp.1999.0121

**Tischer, M. L., \& Phillips, R. V. (1979). Relationship between transportation perceptions and behavior over time. Transportation (Netherlands), 8(1), p. 21-36 
Tranfield, D. R., Denyer, D., \& Smart, P. (2003). Towards a methodology for developing evidence-informed management knowledge by means of systematic review. British journal of management, 14, 207-222

Triandis, H. C. (1977). Interpersonal behavior. Monterey, CA: Brooks/Cole Publishing Company.

Ulfarsson, G. F., \& Shankar, V. N. (2008). Children's travel to school: discrete choice modeling of correlated motorized and nonmotorized transportation modes using covariance heterogeneity. Environment and Planning B-Planning \& Design, 35(2), 195-206. doi: 10.1068/b3360

*Van Acker, V., Mokhtarian, P. L., \& Witlox, F. (2011). Going soft: on how Subjective Variables Explain Modal Choices for Leisure Travel. European Journal of Transport and Infrastructure Research, 11(2), 115-146

**Van Vugt, M., Meertens, R. M., \& Van Lange, P. A. M. (1995). Car Versus Public Transportation? The Role of Social Value Orientations In a Real-Life Social Dilemma. Journal of Applied Social Psychology, 25(3), 258-278

**Van Vugt, M., van Lange, P. A. M., \& Meertens, R. M. (1996). Commuting by car or public transportation? A social dilemma analysis of travel mode judgements. European Journal of Social Psychology, 26(3), 373-395

**Verplanken, B., Aarts, H., van Knippenberg, A., \& Moonen, A. (1998). Habit versus planned behaviour: A field experiment. The British Journal of Social Psychology, 37, 111-128

**Verplanken, B., Aarts, H., van Knippenberg, A., \& van Knippenberg, C. (1994). Attitude versus general habit: Antecedents of travel mode choice. Journal of Applied Social Psychology, 24(4), 285-300. doi: 10.1111/j.1559-1816.1994.tb00583.x

Verplanken, B., \& Roy, D. (2016). Empowering interventions to promote sustainable lifestyles: Testing the habit discontinuity hypothesis in a field experiment. Journal of Environmental Psychology, 45, 127-134.

**Verplanken, B., Walker, I., Davis, A., \& Jurasek, M. (2008). Context change and travel mode choice: Combining the habit discontinuity and self-activation hypotheses. Journal of Environmental Psychology, 28(2), 121-127. doi: 10.1016/j.jenvp.2007.10.005

Von Elm, E., Altman, D. G., Egger, M., Pocock, S. J., Gøtzsche, P. C., Vandenbroucke, J. P., \& Strobe Initiative. (2007). The Strengthening the Reporting of Observational Studies 
in Epidemiology (STROBE) statement: guidelines for reporting observational studies. Preventive medicine, 45(4), 247-251.

Walker, I., Thomas, G. O., \& Verplanken, B. (2015). Old habits die hard travel habit formation and decay during an office relocation. Environment and Behavior, 47(10), 1089-1106

Wener, R. E., \& Evans, G. W. (2007). A Morning Stroll. Levels of Physical Activity in Car and Mass Transit Commuting. Environment \& Behavior, 39(1), 62-74. doi: http://dx.doi.org/10.1177/0013916506295571

Wong, W. C., Cheung, C. S., \& Hart, G. J. (2008). Development of a quality assessment tool for systematic reviews of observational studies (QATSO) of HIV prevalence in men having sex with men and associated risk behaviours. Emerging themes in epidemiology, 5(1), 1.

**Yang-Wallentin, F., Schmidt, P., Davidov, E., \& Bamberg, S. (2004). Is there any interaction effect between intention and perceived behavioral control. Methods of Psychological Research Online, 8(2), 127-157

Young, K., Ashby, D., Boaz, A., \& Grayson, L. (2002). Social Science and the Evidencebased Policy Movement. Social Policy and Society, 1(3), 215-224 


\section{Supplementary File for: What Cognitive Mechanisms Predict Travel Mode Choice? A Systematic Review with Meta-Analysis}

The systematic review appraises transportation research that investigates potentiallymodifiable cognitive determinants (cognitive mechanisms) of travel mode choice. This supplementary file provides further details about methods used and shows all information extracted from the studies that formed the basis for quantitative and qualitative synthesis. Table S1 in Chapter 1 illustrates search methods. Tables S2 and S3 in Chapter 2 display quantified study characteristics as well as data extracted from all included studies. Chapter 3 provides additional information with regards to the assessment of study quality. Tables S6 and $\mathrm{S} 7$ in Chapter 4 show a detailed overview of identified cognitive mechanisms together with a definition and the relative prevalence of investigation into these. Finally, Chapter 5 gives further clarification into decisions with regards to meta-analyses. To be directed to a specific table, please press Ctrl and click on the relevant link in the table of contents. Press Ctrl+Home to get back to this page.

\section{Contents}

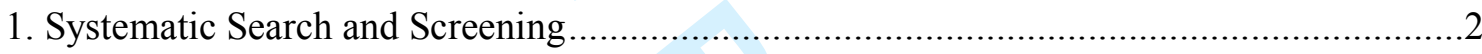

Table S1. Illustration of a systematic review search strategy............................................................ 2

2. Characteristics of Included Studies ..........................................................................

Table S2. Study characteristics of different sub-groups .............................................................. 5

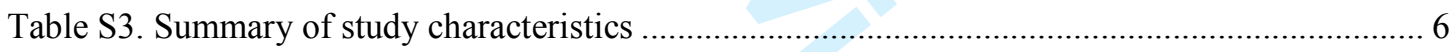



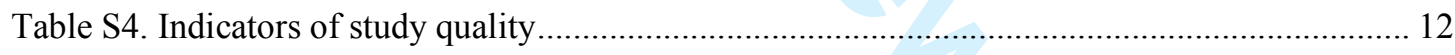

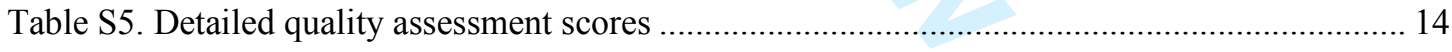

4. Cognitive Mechanisms of Travel Mode Choice ..........................................................31

Table S6. Overview of cognitive mechanisms studied and number of associations tested............... 32

Table S7. Definition of emerged categories of cognitive mechanisms ........................................... 33

Figure S1. Number of cognitive mechanisms measured over time.............................................. 35





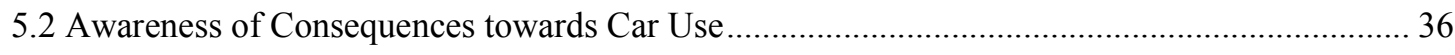

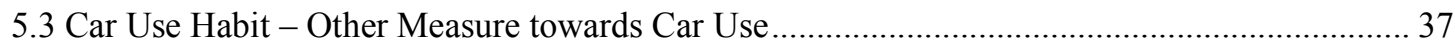

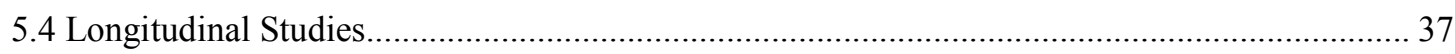

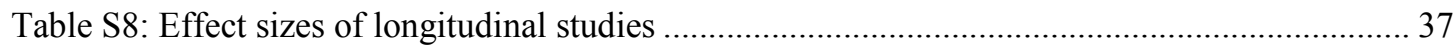

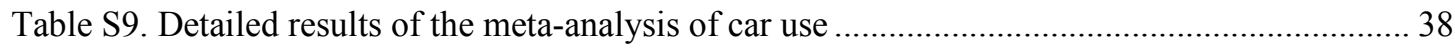

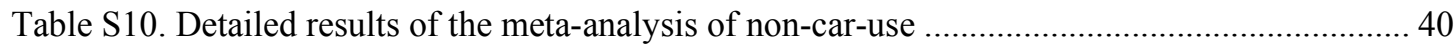






\section{Systematic Search and Screening}

The systematic review searched ten databases: Applied Social Sciences Index and Abstracts, ABI/Inform Complete, ProQuest Sociology, Sociological Abstracts, Web of Science Core Collection, Business Source Complete, Environment Complete, PsychINFO, Psychology and Behavioural Science Collection and Transport Research Information Services Database.

Table S1 shows an example of an applied search strategy for the database Web of Science.

Table S1. Illustration of a systematic review search strategy

Database: Web of Science

Limiters: English, Document Type=Article, Abstract of published item

TS $=(($ Mode NEAR/3 choice $\$)$ OR (Choice\$ NEAR/2 modes) OR (Modal NEAR/2 choice $\$)$ OR (Transport*5 NEAR/3 decision\$) OR (Transport*5 NEAR/3 choice $\$$ ) OR (Travel NEAR/3 decision\$) OR (Travel NEAR/3 choice\$) OR (Modal NEAR/2 switch*3) OR (Mode NEAR/2 switch*3) OR (Modes NEAR/2 switch*3) OR (Mode NEAR/2 shift\$) OR (Modes NEAR/2 shift\$) OR (Modal NEAR/2 shift\$) OR (Modal NEAR/2 split) OR (Mode NEAR/2 split) OR (Modes NEAR/2 split) OR (Mode NEAR/2 share) OR (Modes NEAR/2 share) OR (Modal NEAR/2 share) OR (Multimodal NEAR/2 transport*5) OR (Transport*5 NEAR/3 mode) OR (Transport*5 NEAR/3 modes) OR (Travel NEAR/3 mode) OR (Travel NEAR/3 modes) OR (Mode NEAR/3 change $\$$ ) OR (Modes NEAR/2 change $\$$ ) OR (Modal NEAR/3 use) OR (Mode NEAR/3 use) OR (Modes NEAR/3 use) OR (Mode NEAR/3 select*3) OR (Modal NEAR/2 selection) OR (travel NEAR/10 behavio\$r) OR (commut*3 NEAR/10 behavio\$r) OR (transport*5 NEAR/10 behavio $\$ r$ ))

AND

TS=(((Cogniti*2) OR (Antecedent\$) OR (Determin*3) OR (Correlate\$) OR (Expla*7) OR (Motivat*3) OR (Cause\$) OR (Causing) OR (Predict*3) OR (Effect\$) OR (Mechanism\$) OR (Regulat*3) OR (Influen*4) OR (Control*4) OR (Mediat*2) OR (Moderat*2) OR (affects) OR measure\$) OR relationship OR role\$ OR factor\$ OR psychol*4)

AND

$\mathrm{TS}=(($ Public N/2 transport*5) OR (Private N/2 travel) OR (Private N/2 transport*5) OR Driving OR Automobile\$ OR (Car N/2 driver\$) OR (Car N/2 dependenc\$) OR (Car N/2 use) OR car OR cars OR (Car N/2 owner*4))

Overall, 4,156 records were initially identified. After removing 805 duplicates 3,393 unique citations remained for title and abstract screening. 3,005 were deemed not relevant, leaving 388 references for further investigation of full texts. If necessary, authors were contacted to request the full text of inaccessible studies $(N=19)$. Following these inclusion criteria, a full text screening identified 47 studies to be eligible for inclusion. Four data sets were found to underpin more than one paper, leading to the exclusion of four studies to avoid doublecounting. Frequently, studies only test a relationship between a cognitive mechanism and 
2

intention or measured a non-cognitive or affective mechanism. Some publications focussed on elderly or children only. A few studies were excluded on the basis of not representing travel in general. Reduced chauffeur trips to school is an important behaviour change target as it can contribute to increased physical activity in children (Cooper et al., 2010). School runs cannot be looked at in isolation but interdependencies with travel patterns of parents should be taken into account (McDonald, 2008). Likewise, the decision to drive children to school is often a result of intra-household interactions, composition and shared responsibilities rather than individual intrinsically-motivated travel mode choice (Yarlagadda \& Srinivasan, 2007). It can therefore be argued that school runs can be classified as an agent of socialisation (Baslington, 2008). As a result, different cognitive mechanisms underpin school travel mode choice of parents, e.g. worry about safety (Ahlport, Linnan, Vaughn, Evenson, \& Ward, 2008; DiGuiseppi, Roberts, Li, \& Allen, 1998). We therefore did not include school runs in our systematic review and recommend separate analysis of such studies. 


\section{Characteristics of Included Studies}

Based on 42 studies that reported the sample size, the mean was 584, ranging from 56 to 2000 participants. Only 32 studies (74.42\%) reported the mean age of their sample (min 24.5, max 50.8, average 38.29) and even less specified the $\operatorname{SD}(N=9,20.94 \%)$. No information could be extracted from six studies with regards to gender distribution so that, based on 37 studies, the average percentage of female participants was 54\%. In 15 studies (40.54\%) the proportion of the female population was $55 \%$ and above and $60 \%$ or more in seven out of 37 studies (19.92\%). Seven studies (16.28\%) sampled students only. Information concerning car ownership or access and driver's licence varied across studies, with participants consisting of only drivers or only commuters, but also a mixed population with non-car owners. For example, 23 out of 38 studies (60.53\%) reported that their sample consisted of driver's license holders only, with at least frequent access to a car. Five studies did not report details with regards to driver's licence or car access. The majority of studies applied a cross-sectional design $(N=26,60.47 \%)$. Experimental studies $(N=7 ; 16.28 \%)$ and prospective studies $(N=$ $6 ; 13.95 \%$ ) were conducted less frequently. A longitudinal approach was the least frequently employed study design $(N=4,9.3 \%)$. Only $16.28 \%(N=7)$ of all studies were conducted outside of Europe with the majority of these from the USA $(N=3)$ and Australia $(N=3)$. Within Europe, Germany $(N=13)$ and the Netherlands $(N=8)$ were major contributors to the TMC literature, accounting for $48.84 \%$ of all included studies. Table S2 summarises the extracted study characteristics and shows the number of incidences for different sub-groups. The more detailed evidence table can be found in Table S3, presenting summarised characteristics of each individual study. 
Table S2. Study characteristics of different sub-groups

\begin{tabular}{|c|c|c|c|c|}
\hline & $\begin{array}{l}\text { All studies } \\
\text { included in } \\
\text { the review }\end{array}$ & $\begin{array}{l}\text { Studies that } \\
\text { applied a } \\
\text { theoretical } \\
\text { framework }\end{array}$ & $\begin{array}{l}\text { Studies that } \\
\text { applied TPB }\end{array}$ & $\begin{array}{l}\text { Studies } \\
\text { included in } \\
\text { Meta- } \\
\text { Analysis }\end{array}$ \\
\hline & $\begin{array}{l}\text { Number and } \\
\% \text { of } N=43\end{array}$ & $\begin{array}{l}\text { Number and } \\
\% \text { of } N=24\end{array}$ & $\begin{array}{l}\text { Number and } \\
\% \text { of } N=16\end{array}$ & $\begin{array}{l}\text { Number and } \\
\% \text { of } N=35\end{array}$ \\
\hline \multicolumn{5}{|l|}{ Study design } \\
\hline Cross-sectional & $26(60.47)$ & $13(54.17)$ & $9(56.25)$ & $22(62.86)$ \\
\hline Experimental & $7(16.28)$ & $5(20.84)$ & $2(12.5)$ & $6(17.14)$ \\
\hline Longitudinal & $4(9.3)$ & $1(4.17)$ & $1(6.25)$ & $3(8.57)$ \\
\hline Prospective & $6(13.95)$ & $5(20.84)$ & $4(25)$ & $4(11.43)$ \\
\hline \multicolumn{5}{|l|}{ Study Context } \\
\hline Commuting & $19(44.19)$ & $10(41.67)$ & $6(37.5)$ & $14(40)$ \\
\hline General Purpose & $23(53.49)$ & $14(58.34)$ & $10(62.5)$ & $20(57.14)$ \\
\hline Not reported & $1(2.33)$ & - & - & $1(2.86)$ \\
\hline Study Setting & $3 \sqrt{2}$ & & & \\
\hline Urban & $27(62.79)$ & $17(70.84)$ & $10(62.5)$ & $20(57.14)$ \\
\hline Mixed & $8(18.60)$ & $4(16.67)$ & $3(18.75)$ & $7(20)$ \\
\hline Rural & $3(6.98)$ & $2(8.34)$ & $2(12.5)$ & $3(8.57)$ \\
\hline Not reported & $5(11.63)$ & $1(4.17)$ & $1(6.35)$ & $4(11.43)$ \\
\hline \multicolumn{5}{|l|}{ Geographical Location } \\
\hline UK & $7(16.28)$ & $5(20.84)$ & $4(25)$ & $7(20)$ \\
\hline Germany & $13(30.23)$ & $10(41.67)$ & $7(43.75)$ & $9(25.71)$ \\
\hline Australia & $3(6.98)$ & $2(8.34)$ & $1(6.25)$ & $2(5.71)$ \\
\hline Netherlands & $8(18.60)$ & $4(16.67)$ & $2(12.5)$ & $7(20)$ \\
\hline Canada & $1(2.33)$ & $1(4.17)$ & $1(6.25)$ & $1(2.86)$ \\
\hline Switzerland & $2(4.65)$ & $2(8.34)$ & $1(6.25)$ & $2(5.71)$ \\
\hline Sweden & $4(9.30)$ & - & - & $4(11.43)$ \\
\hline USA & $3(6.98)$ & - & 8 & $2(5.71)$ \\
\hline Spain & $1(2.33)$ & - & - & $1(2.86)$ \\
\hline Belgium & $1(2.33)$ & - & - & - \\
\hline \multicolumn{5}{|l|}{ Dependent Variable } \\
\hline Car-use & $32(74.42)$ & $16(66.67)$ & $11(68.75)$ & $26(74.29)$ \\
\hline Non-car-use & $11(25.58)$ & $8(33.34)$ & $5(31.25)$ & $9(25.71)$ \\
\hline Unclear & $1(2.33)$ & - & - & - \\
\hline \multicolumn{5}{|l|}{ Population } \\
\hline Total Sample Size & 24517 & 11584 & 10130 & 18770 \\
\hline Average $\%$ female & 54 & 54.95 & 60.66 & 54.64 \\
\hline Age (grand mean) & 38.29 & 39.61 & 39.2 & 39.2 \\
\hline Min mean age & 24.5 & 24.5 & 24.5 & 24.7 \\
\hline Max mean age & 50.77 & 50.77 & 50.77 & 50.77 \\
\hline
\end{tabular}


Table S3. Summary of study characteristics

\begin{tabular}{|c|c|c|c|c|c|c|}
\hline Author(s) (year) & $\begin{array}{l}\text { Country } \\
\text { (Sample Size; } \\
\text { \%female; mean age } \\
{[\text { SD], age range) }}\end{array}$ & Setting & $\begin{array}{l}\text { Journey } \\
\text { Purpose }\end{array}$ & Design [Analysis] & $\begin{array}{l}\text { Dependent Variable (TMC } \\
\text { Behaviour measure) }\end{array}$ & $\begin{array}{l}\text { Quality } \\
\text { Score }\end{array}$ \\
\hline $\begin{array}{l}\text { Abrahamse et al. } \\
\text { (2009). }\end{array}$ & $\begin{array}{l}\text { Canada } \\
(N=241 ; 66.5 \% \\
18-65 \text { years })\end{array}$ & Urban & Commuting & $\begin{array}{l}\text { Cross-sectional } \\
\text { [Multiple regression } \\
\text { analyses] }\end{array}$ & Car use ratio (typical) & 1.0 \\
\hline $\begin{array}{l}\text { Armitage et al. } \\
(\mathbf{2 0 1 3 )}\end{array}$ & $\begin{array}{l}\text { UK } \\
(N=423 ; 57.2 \% ; \\
50.77[14.33] \\
\text { years })\end{array}$ & Rural & $\begin{array}{l}\text { General } \\
\text { Purpose }\end{array}$ & $\begin{array}{l}\text { Panel } \\
\text { [Hierarchical } \\
\text { regression analysis] }\end{array}$ & Car use frequency (typical) & 1.5 \\
\hline Baldassare (1991) & USA & NR & Commuting & $\begin{array}{l}\text { Cross-sectional } \\
\text { [Regression } \\
\text { analysis] } \\
\end{array}$ & $\begin{array}{l}\text { Car use (SOV) preference } \\
\text { (typical) }\end{array}$ & 1.0 \\
\hline Bamberg (2006) & $\begin{array}{l}\text { Germany } \\
(N=241 ; 53 \% ; \\
28.6[13.9], 17-58 \\
\text { years })\end{array}$ & Urban & $\begin{array}{l}\text { Commuting, } \\
\text { Shopping, } \\
\text { Leisure }\end{array}$ & $\begin{array}{l}\text { Experimental } \\
{[S E M]}\end{array}$ & $\begin{array}{l}\text { PT vs. car use proportion } \\
\text { (actual) }\end{array}$ & 0.1 \\
\hline Bamberg et al. (2003) & $\begin{array}{l}\text { Germany } \\
(N=592 ; 58 \% ; 25, \\
20-37 \text { years })\end{array}$ & Urban & Commuting & $\begin{array}{l}\text { Experimental } \\
\text { [SEM] }\end{array}$ & $\begin{array}{l}\text { Car use proportion (actual) } \\
\text { [DV] }\end{array}$ & 1.0 \\
\hline $\begin{array}{l}\text { Bamberg \& Schmidt } \\
\text { (2003) }\end{array}$ & $\begin{array}{l}\text { Germany } \\
(N=254 ; 24.5 \\
\text { years }) \\
\end{array}$ & Urban & Commuting & $\begin{array}{l}\text { Prospective } \\
{[S E M]}\end{array}$ & $\begin{array}{l}\text { Car use proportion (actual) } \\
\text { [DV] }\end{array}$ & 1.1 \\
\hline Bergstad et al. (2011) & $\begin{array}{l}\text { Sweden } \\
(N=1127 ; 53.7 \% \\
46.3[12.4] \text { years })\end{array}$ & Mixed & $\begin{array}{l}\text { General } \\
\text { Purpose }\end{array}$ & $\begin{array}{l}\text { Cross-sectional } \\
\text { [Regression } \\
\text { Analysis] }\end{array}$ & $\begin{array}{l}\text { Car vs. other mode use } \\
\text { frequency (typical) }\end{array}$ & 1.0 \\
\hline
\end{tabular}




\begin{tabular}{|c|c|c|c|c|c|c|}
\hline Author(s) (year) & $\begin{array}{l}\text { Country } \\
\text { (Sample Size; } \text { \%female; mean age } \\
\text { [SD], age range) }\end{array}$ & Setting & $\begin{array}{l}\text { Journey } \\
\text { Purpose }\end{array}$ & Design [Analysis] & $\begin{array}{l}\text { Dependent Variable (TMC } \\
\text { Behaviour measure) }\end{array}$ & $\begin{array}{l}\text { Quality } \\
\text { Score }\end{array}$ \\
\hline $\begin{array}{l}\text { Cao \& Mokhtarian } \\
(2005)\end{array}$ & $\begin{array}{l}\text { USA } \\
(N=1283 ; 50.9 \%)\end{array}$ & Mixed & Commuting & $\begin{array}{l}\text { Cross-sectional } \\
\text { [Binary logit model] }\end{array}$ & $\begin{array}{l}\text { Car use preference (typical) } \\
\text { [DV] }\end{array}$ & 1.0 \\
\hline $\begin{array}{l}\text { Collins \& Chambers } \\
\text { (2005) }\end{array}$ & $\begin{array}{l}\text { Australia } \\
(N=205 ; 50 \% ; 18- \\
58 \text { years })\end{array}$ & Urban & Commuting & $\begin{array}{l}\text { Cross-sectional } \\
\text { [Multiple regression } \\
\text { analysis] }\end{array}$ & $\begin{array}{l}\text { PT vs. Car use preference } \\
\text { (typical) }\end{array}$ & 0.9 \\
\hline Davidov (2007) & $\begin{array}{l}\text { Germany } \\
(N=123 ; 44 \%)\end{array}$ & Urban & NR & $\begin{array}{l}\text { Experimental } \\
\text { [Binary logit } \\
\text { regression analysis] }\end{array}$ & $\begin{array}{l}\text { Car use vs. PT use } \\
\text { frequency (actual) [DV] }\end{array}$ & 0.5 \\
\hline $\begin{array}{l}\text { Friedrichsmeier et al. } \\
\text { (2013) }\end{array}$ & $\begin{array}{l}\text { Germany } \\
(N=1048 ; 53.4 \%)\end{array}$ & Urban & $\begin{array}{l}\text { Commuting, } \\
\text { Shopping, } \\
\text { Leisure }\end{array}$ & $\begin{array}{l}\text { Prospective } \\
\text { [Correlation } \\
\text { analysis] } \\
\end{array}$ & Car use ratio (actual) & 0.3 \\
\hline Gardner (2009) & $\begin{array}{l}\text { UK } \\
(N=107 ; 69.16 \% \\
27.53[9.69], 18-55 \\
\text { years })\end{array}$ & NR & Commuting & $\begin{array}{l}\text { Prospective } \\
\text { [Hierarchical } \\
\text { regression analysis] }\end{array}$ & $\begin{array}{l}\text { Car use vs. non-car mode } \\
\text { use ratio (actual) }\end{array}$ & 1.8 \\
\hline $\begin{array}{l}\text { Gardner \& Abraham } \\
\text { (2010) }\end{array}$ & $\begin{array}{l}\text { UK } \\
(N=190 ; 60.53 \% \\
36.9[18.2], 18-86 \\
\text { years })\end{array}$ & Urban & $\begin{array}{l}\text { General } \\
\text { purpose }\end{array}$ & $\begin{array}{l}\text { Cross-sectional } \\
\text { [Multiple regression } \\
\text { analysis] }\end{array}$ & $\begin{array}{l}\text { Car (incl taxi) vs. other } \\
\text { mode use ratio (typical) }\end{array}$ & 2.0 \\
\hline Gärling et al. (2001) & $\begin{array}{l}\text { Sweden } \\
(N=60 ; 50 \% ; 27.4 \\
[6.9], 20-49 \text { years })\end{array}$ & NR & Commuting & $\begin{array}{l}\text { Cross-sectional } \\
{[S E M]}\end{array}$ & Car use frequency (typical) & 0.8 \\
\hline $\begin{array}{l}\text { Golob \& Hensher } \\
\text { (1998) }\end{array}$ & $\begin{array}{l}\text { Australia } \\
(N=963)\end{array}$ & Urban & Commuting & $\begin{array}{l}\text { Cross-sectional } \\
{[S E M]}\end{array}$ & $\begin{array}{l}\text { Car use (SOV) frequency } \\
\text { (typical) }\end{array}$ & 1.0 \\
\hline Harland et al. (1999) & $\begin{array}{l}\text { Netherlands } \\
(N=198 ; 78.7 \% ; \\
47 \text { years })\end{array}$ & NR & Short distance & $\begin{array}{l}\text { Cross-sectional } \\
\text { [Hierarchical } \\
\text { regression analysis] }\end{array}$ & $\begin{array}{l}\text { Non-car use frequency } \\
\text { (typical) }\end{array}$ & 0.8 \\
\hline
\end{tabular}




\begin{tabular}{|c|c|c|c|c|c|c|}
\hline Author(s) (year) & $\begin{array}{l}\text { Country } \\
\text { (Sample Size; } \\
\text { \%female; mean age } \\
{[\text { SD], age range) }}\end{array}$ & Setting & $\begin{array}{l}\text { Journey } \\
\text { Purpose }\end{array}$ & Design [Analysis] & $\begin{array}{l}\text { Dependent Variable (TMC } \\
\text { Behaviour measure) }\end{array}$ & $\begin{array}{l}\text { Quality } \\
\text { Score }\end{array}$ \\
\hline $\begin{array}{l}\text { Haustein \& Hunecke } \\
\text { (2007) }\end{array}$ & $\begin{array}{l}\text { Germany } \\
(N=1545 ; 50 \% ; \\
46.5,18-80 \text { years })\end{array}$ & Urban & $\begin{array}{l}\text { Commuting, } \\
\text { Shopping, } \\
\text { Leisure }\end{array}$ & $\begin{array}{l}\text { Cross-sectional } \\
{[S E M]}\end{array}$ & $\begin{array}{l}\text { Environmentally friendly } \\
\text { mode use (incl. walking, } \\
\text { cycling, PT [bus, } \\
\text { tram/subway, } \\
\text { regional train, long-distance } \\
\text { train]) vs. car use (inlc. } \\
\text { Motorcycle, car share,rental } \\
\text { car, taxi) ratio (typical) }\end{array}$ & 3.0 \\
\hline Hunecke et al. (2001) & $\begin{array}{l}\text { Germany } \\
(N=160 ; 46.3 \%)\end{array}$ & Urban & City centre & $\begin{array}{l}\text { Experimental, } \\
\text { prospective } \\
{[A N O V A]}\end{array}$ & $\begin{array}{l}\text { Subway vs car use ratio } \\
\text { (actual) }\end{array}$ & 0.9 \\
\hline Hunecke et al. (2007) & $\begin{array}{l}\text { Germany } \\
(N=1991 ; 53 \%)\end{array}$ & Urban & $\begin{array}{l}\text { General } \\
\text { purpose }\end{array}$ & $\begin{array}{l}\text { Cross-sectional } \\
\text { [Hierarchical } \\
\text { regression analysis] }\end{array}$ & $\begin{array}{l}\text { Car use (incl. Motorcycle, } \\
\text { car share, rental cars, taxis) } \\
\text { vs. environmentally friendly } \\
\text { mode use (Walking, } \\
\text { cycling, PT [bus, } \\
\text { tram/subway, } \\
\text { regional train, long-distance } \\
\text { train]) ratio (typical) }\end{array}$ & 2.0 \\
\hline $\begin{array}{l}\text { Joireman et al. } \\
\text { (1997), }\end{array}$ & $\begin{array}{l}\text { Netherlands } \\
(N=102 ; 37.25 \% \\
33.2 \text { years })\end{array}$ & Urban & Commuting & $\begin{array}{l}\text { Cross-sectional } \\
\text { [Correlation } \\
\text { Analysis] }\end{array}$ & $\begin{array}{l}\text { Car vs PT use preference } \\
\text { (typical) }\end{array}$ & 0.0 \\
\hline $\begin{array}{l}\text { Kaiser \& Gutscher } \\
\text { (2003) }\end{array}$ & $\begin{array}{l}\text { Switzerland } \\
(N=895 ; 46.4,18- \\
79 \text { years })\end{array}$ & Mixed & City centre & $\begin{array}{l}\text { Cross-sectional } \\
\text { [Multiple regression } \\
\text { analysis] }\end{array}$ & $\begin{array}{l}\text { Non-car use frequency } \\
\text { (typical) }\end{array}$ & 1.0 \\
\hline Kerr et al. (2010) & $\begin{array}{l}\text { Australia } \\
(N=186 ; 79 \%)\end{array}$ & Urban & Commuting & $\begin{array}{l}\text { Cross-sectional } \\
\text { [Hierarchical }\end{array}$ & Car use frequency (typical) & 1.0 \\
\hline
\end{tabular}




\begin{tabular}{|c|c|c|c|c|c|c|}
\hline Author(s) (year) & $\begin{array}{l}\text { Country } \\
\text { (Sample Size; } \\
\% \text { female; mean age } \\
\text { [SD], age range) }^{\mathrm{a}}\end{array}$ & Setting & $\begin{array}{l}\text { Journey } \\
\text { Purpose }\end{array}$ & Design [Analysis] & $\begin{array}{l}\text { Dependent Variable (TMC } \\
\text { Behaviour measure) }\end{array}$ & $\begin{array}{l}\text { Quality } \\
\text { Score }\end{array}$ \\
\hline & & & & regression analysis] & & \\
\hline $\begin{array}{l}\text { Klöckner \& } \\
\text { Blöbaum (2010) }\end{array}$ & $\begin{array}{l}\text { Germany } \\
(N=389 ; 60.7 \% \\
24.7,19-52 \text { years }) \\
\end{array}$ & Urban & $\begin{array}{l}\text { General } \\
\text { purpose }\end{array}$ & $\begin{array}{l}\text { Prospective } \\
\text { [SEM] }\end{array}$ & Car use ratio (actual) & 2.0 \\
\hline $\begin{array}{l}\text { Klöckner \& Matthies } \\
\text { (2004) }\end{array}$ & $\begin{array}{l}\text { Germany } \\
(N=160 ; 36.9 \% \\
38.5,19-78 \text { years })\end{array}$ & Urban & Commuting & $\begin{array}{l}\text { Prospective } \\
\text { [Binary logistic } \\
\text { regressions } \\
\text { analysis] }\end{array}$ & $\begin{array}{l}\text { PT vs car use ratio (actual) } \\
\text { [DV] }\end{array}$ & 0.6 \\
\hline \multirow{4}{*}{$\begin{array}{l}\text { Lois \& Lopez-Saez } \\
(2009)\end{array}$} & \multirow{4}{*}{$\begin{array}{l}\text { Spain } \\
(N=284 ; 50.3 \% \\
34.4[10.43] \text { years })\end{array}$} & \multirow{4}{*}{ Urban } & Shopping & \multirow{4}{*}{$\begin{array}{l}\text { Cross-sectional } \\
\text { [SEM] }\end{array}$} & $\begin{array}{l}\text { Car use frequency (typical) - } \\
\text { Shopping }\end{array}$ & \multirow{4}{*}{2.0} \\
\hline & & & $\begin{array}{l}\text { visiting } \\
\text { friends/family }\end{array}$ & & $\begin{array}{l}\text { Car use frequency (typical) - } \\
\text { visiting friends/family }\end{array}$ & \\
\hline & & & commuting & & $\begin{array}{l}\text { Car use frequency (typical) - } \\
\text { commuting }\end{array}$ & \\
\hline & & & leisure trips & & $\begin{array}{l}\text { Car use frequency (typical) - } \\
\text { leisure trips }\end{array}$ & \\
\hline $\begin{array}{l}\text { Mann \& Abraham } \\
\text { (2012) }\end{array}$ & $\begin{array}{l}\text { UK } \\
(N=229 ; 49.78 \% \\
40.59,19-76 \text { years })\end{array}$ & Mixed & Commuting & $\begin{array}{l}\text { Prospective } \\
\text { [Hierarchical } \\
\text { regression analyses] }\end{array}$ & Car use ratio (actual) & 2.0 \\
\hline Matthies et al. (2006) & $\begin{array}{l}\text { Germany } \\
(N=297 ; 37.7 \% \\
45 \text { years })\end{array}$ & Urban & $\begin{array}{l}\text { General } \\
\text { purpose }\end{array}$ & $\begin{array}{l}\mathrm{RCT} \\
\text { [Multiple logistic } \\
\text { regression analysis] }\end{array}$ & Car-use ratio (actual) & 0.3 \\
\hline \multirow[b]{2}{*}{ Murtagh et al. (2012) } & \multirow{2}{*}{$\begin{array}{l}\text { UK } \\
(N=419 ; 62 \% ; 40, \\
20-61 \text { years })\end{array}$} & \multirow[b]{2}{*}{ Urban } & Commuting & \multirow{2}{*}{$\begin{array}{l}\text { Cross-sectional } \\
\text { [Multiple regression } \\
\text { analysis] }\end{array}$} & \multirow{2}{*}{ Car use ratio (typical) } & \multirow[b]{2}{*}{3.0} \\
\hline & & & $\begin{array}{l}\text { General } \\
\text { Purpose }\end{array}$ & & & \\
\hline $\begin{array}{l}\text { Nilsson \& Küller } \\
(2000)\end{array}$ & $\begin{array}{l}\text { Sweden } \\
(N=157 ; 58 \% ; 40\end{array}$ & Urban & $\begin{array}{l}\text { General } \\
\text { Purpose }\end{array}$ & $\begin{array}{l}\text { Cross-sectional } \\
\text { [Hierarchical }\end{array}$ & $\begin{array}{l}\text { Mode use frequency } \\
\text { (typical) }\end{array}$ & 0.7 \\
\hline
\end{tabular}




\begin{tabular}{|c|c|c|c|c|c|c|}
\hline Author(s) (year) & $\begin{array}{l}\text { Country } \\
\text { (Sample Size; } \\
\text { \%female; mean age } \\
{[\text { SD], age range) }}\end{array}$ & Setting & $\begin{array}{l}\text { Journey } \\
\text { Purpose }\end{array}$ & Design [Analysis] & $\begin{array}{l}\text { Dependent Variable (TMC } \\
\text { Behaviour measure) }\end{array}$ & $\begin{array}{l}\text { Quality } \\
\text { Score }\end{array}$ \\
\hline & years) & & & regression analysis] & & \\
\hline Panter et al. (2013) & $\begin{array}{l}\text { UK } \\
(N=137 ; 76.6 \% \\
43.7[11.9] \text { years })\end{array}$ & Mixed & Commuting & $\begin{array}{l}\text { Panel } \\
\text { [logistic regression] }\end{array}$ & $\begin{array}{l}\text { Car use frequency (typical) } \\
\text { [DV] }\end{array}$ & 0.7 \\
\hline Polk (2003) & $\begin{array}{l}\text { Sweden } \\
(N=1145 ; 18-80 \\
\text { years })\end{array}$ & Mixed & $\begin{array}{l}\text { Commuting, } \\
\text { General } \\
\text { purpose } \\
\end{array}$ & $\begin{array}{l}\text { Cross-sectional } \\
\text { [Correlation } \\
\text { analysis] }\end{array}$ & Car use frequency (typical) & 1.0 \\
\hline $\begin{array}{l}\text { Scheiner \& Holz-Rau } \\
(2007)\end{array}$ & $\begin{array}{l}\text { Germany } \\
(N=2690)\end{array}$ & Urban & $\begin{array}{l}\text { General } \\
\text { purpose }\end{array}$ & $\begin{array}{l}\text { Cross-sectional } \\
{[S E M]}\end{array}$ & $\begin{array}{l}\text { Car vs PT use (incl. } \\
\text { motorcycle) ratio (typical) } \\
\text { PT vs. Car use ratio } \\
\text { (typical) }\end{array}$ & 1.0 \\
\hline Steg (2005) & $\begin{array}{l}\text { Netherlands } \\
(N=113 ; 27 \% ; 42 \\
\text { years })\end{array}$ & Urban & Commuting & $\begin{array}{l}\text { Cross-sectional } \\
\text { [Multiple regression } \\
\text { analysis] }\end{array}$ & Car use ratio (typical) & 2.0 \\
\hline Steg \& Sievers (2000) & $\begin{array}{l}\text { Netherlands } \\
(N=413)\end{array}$ & NR & $\begin{array}{l}\text { General } \\
\text { purpose }\end{array}$ & $\begin{array}{l}\text { Cross-sectional } \\
\text { [Correlation } \\
\text { Analysis] } \\
\end{array}$ & Car use frequency (typical) & 0.5 \\
\hline Tanner (1999) & $\begin{array}{l}\text { Switzerland } \\
(N=153 ; 33 \% ; 46 \\
\text { years })\end{array}$ & Mixed & $\begin{array}{l}\text { Commuting, } \\
\text { Shopping, } \\
\text { Leisure } \\
\end{array}$ & $\begin{array}{l}\text { Cross-sectional } \\
\text { [Multiple regression } \\
\text { analyses] }\end{array}$ & $\begin{array}{l}\text { Car (incl. motorcycle) use } \\
\text { frequency index (typical) }\end{array}$ & 1.0 \\
\hline $\begin{array}{l}\text { Tischer \& Phillips } \\
\text { (1979) }\end{array}$ & $\begin{array}{l}\text { USA } \\
(N=502)\end{array}$ & Urban & Commuting & $\begin{array}{l}\text { Panel study } \\
\text { [Cross-lagged } \\
\text { correlation] }\end{array}$ & $\begin{array}{l}\text { Car use vs. bus vs. car pool } \\
\text { ratio (typical) }\end{array}$ & 0.0 \\
\hline $\begin{array}{l}\text { Van Acker et al. } \\
\text { (2011) }\end{array}$ & $\begin{array}{l}\text { Belgium } \\
(N=1878 ; 58.7 \% ;\end{array}$ & Urban & $\begin{array}{l}\text { active leisure } \\
\text { activities }\end{array}$ & $\begin{array}{l}\text { Cross-sectional } \\
{[S E M]}\end{array}$ & $\begin{array}{l}\text { Car use frequency (typical) } \\
\text { [DV] }\end{array}$ & 1.5 \\
\hline
\end{tabular}









\section{Methodological Quality Assessment}

Table S4 presents the criteria used to determine methodological quality assessing sample size, sample representativeness and validity and reliability of measures used.

Table S4. Indicators of study quality

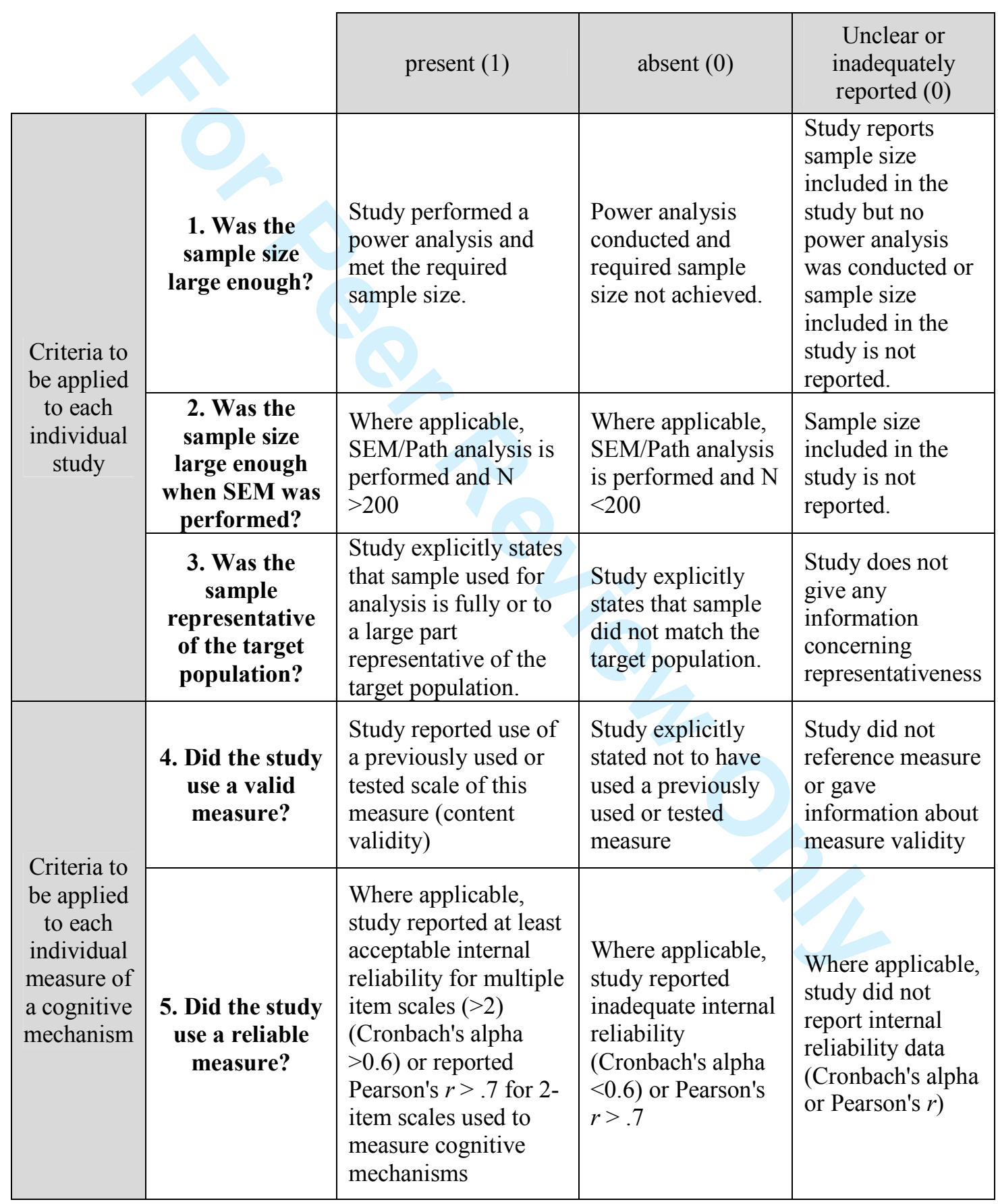


High quality studies achieved an average score of 2.28, medium quality studies 1.16 and low quality studies 0.43 . Three studies did not meet any of the quality criteria (Joireman, Van Lange, Kuhlman, Van Vugt, \& Shelley, 1997; Tischer \& Phillips, 1979; van Vugt, van Lange, $\&$ Meertens, 1996). Two studies met all quality assessment criteria and achieved a maximum score of 3 (Haustein \& Hunecke, 2007; Murtagh, Gatersleben, \& Uzzell, 2012). Studies with a prospective research design scored highest $(\mathrm{M}=1.3)$, followed by cross-sectional studies $(\mathrm{M}$ $=1.2)$, longitudinal studies $(\mathrm{M}=0.8)$. Experimental studies presented the lowest average quality rating $(\mathrm{M}=0.5)$. Independent scores for each quality indicator can be found in Table S5. 
Table S5. Detailed quality assessment scores

\begin{tabular}{|c|c|c|c|c|c|c|c|}
\hline \multirow[b]{2}{*}{ Author(s) (year) } & \multirow[b]{2}{*}{ Cognitive Mechanism(s) } & \multicolumn{6}{|c|}{ Indicators of Study Quality } \\
\hline & & reliable & valid & $\begin{array}{l}\text { Large } \\
\text { sample } \\
\text { (Power } \\
\text { Analysis) }\end{array}$ & $\begin{array}{l}\text { Large } \\
\text { Sample } \\
\text { (SEM/Path } \\
=>200)\end{array}$ & $\begin{array}{l}\text { Repres } \\
\text { entativ } \\
\text { eness }\end{array}$ & $\begin{array}{l}\text { Total } \\
\text { Score }\end{array}$ \\
\hline \multirow{7}{*}{$\begin{array}{l}\text { Abrahamse et al. } \\
\text { (2009) }\end{array}$} & Intentions - Non-car use & $\mathrm{n} / \mathrm{a}$ & 1 & \multirow{7}{*}{0} & \multirow{7}{*}{$\mathrm{n} / \mathrm{a}$} & \multirow{7}{*}{0} & \multirow{7}{*}{1.0} \\
\hline & Attitudes - Car use & 1 & 1 & & & & \\
\hline & SN - Car use expectation & $\mathrm{n} / \mathrm{a}$ & 1 & & & & \\
\hline & PBC - non-car use & 1 & 1 & & & & \\
\hline & PN - car and non-car use & 1 & 1 & & & & \\
\hline & Awareness of Consequences - Car use & 1 & 1 & & & & \\
\hline & Ascription of responsibilities - Car use & 1 & 1 & & & & \\
\hline \multirow{4}{*}{ Armitage et al. (2013) } & PBC - reduce car use & 1 & 0 & \multirow{4}{*}{0} & \multirow{4}{*}{$\mathrm{n} / \mathrm{a}$} & \multirow{4}{*}{1} & \multirow{4}{*}{1.5} \\
\hline & Attitudes - reduce car use & 1 & 0 & & & & \\
\hline & SN - reduce car use & 1 & 0 & & & & \\
\hline & Intention - reduce car use & 1 & 0 & & & & \\
\hline \multirow{2}{*}{ Baldassare (1991) } & Attitudes about freeway satisfaction & $\mathrm{n} / \mathrm{a}$ & 0 & \multirow{2}{*}{0} & \multirow{2}{*}{$\mathrm{n} / \mathrm{a}$} & \multirow{2}{*}{1} & \multirow{2}{*}{1.0} \\
\hline & Attitudes about traffic problems & $\mathrm{n} / \mathrm{a}$ & 0 & & & & \\
\hline \multirow{6}{*}{ Bamberg (2006) } & Intention - PT vs Car & 0 & 0 & \multirow{6}{*}{$\mathrm{n} / \mathrm{a}$} & \multirow{6}{*}{0} & \multirow{6}{*}{0} & \multirow{6}{*}{0.1} \\
\hline & Attitude - PT vs Car & 0 & 0 & & & & \\
\hline & PBC - PT vs Car & 0 & 0 & & & & \\
\hline & Change Intention - PT vs car & 0 & 0 & & & & \\
\hline & SN - PT vs car & 0 & 0 & & & & \\
\hline & Habit - Car vs PT & $\mathrm{n} / \mathrm{a}$ & 1 & & & & \\
\hline \multirow{5}{*}{ Bamberg et al. (2003) } & Intention - Car use & 0 & 0 & \multirow{5}{*}{$\mathrm{n} / \mathrm{a}$} & \multirow{5}{*}{1} & \multirow{5}{*}{0} & \multirow{5}{*}{1.0} \\
\hline & Habit & 0 & 0 & & & & \\
\hline & Attitudes - Car use & 0 & 0 & & & & \\
\hline & SN - Car use & 0 & 0 & & & & \\
\hline & PBC - Car use & 0 & 0 & & & & \\
\hline
\end{tabular}




\begin{tabular}{|c|c|c|c|c|c|c|c|}
\hline \multirow[b]{2}{*}{ Author(s) (year) } & \multirow[b]{2}{*}{ Cognitive Mechanism(s) } & \multicolumn{6}{|c|}{ Indicators of Study Quality } \\
\hline & & reliable & valid & $\begin{array}{l}\text { Large } \\
\text { sample } \\
\text { (Power } \\
\text { Analysis) }\end{array}$ & $\begin{array}{l}\text { Large } \\
\text { Sample } \\
\text { (SEM/Path } \\
=>200 \text { ) }\end{array}$ & $\begin{array}{l}\text { Repres } \\
\text { entativ } \\
\text { eness }\end{array}$ & $\begin{array}{l}\text { Total } \\
\text { Score }\end{array}$ \\
\hline \multirow{13}{*}{$\begin{array}{l}\text { Bamberg \& Schmidt } \\
\text { (2003) }\end{array}$} & Role beliefs - Car use & 0 & 0 & \multirow{13}{*}{$\mathrm{n} / \mathrm{a}$} & \multirow{13}{*}{1} & \multirow{13}{*}{0} & \multirow{13}{*}{1.1} \\
\hline & Intention - Car use & 0 & 0 & & & & \\
\hline & SN - Car use & 0 & 0 & & & & \\
\hline & Behavioural beliefs - Car use & 0 & 1 & & & & \\
\hline & Control beliefs - Car use & 0 & 1 & & & & \\
\hline & Normative beliefs - Car use & 0 & 1 & & & & \\
\hline & Ascription of responsibilities - Traffic & 0 & 0 & & & & \\
\hline & Habit - Car use (script-based) & 0 & 0 & & & & \\
\hline & Awareness of consequences - Traffic & 0 & 0 & & & & \\
\hline & PN - non-car use & 0 & 0 & & & & \\
\hline & PBC - Car use & 0 & 0 & & & & \\
\hline & Attitudes - Affective car use & 0 & 0 & & & & \\
\hline & Attitudes - Car use & 0 & 0 & & & & \\
\hline \multirow{9}{*}{ Bergstad et al. (2011) } & $\begin{array}{l}\text { Instrumental motives - visit family and } \\
\text { friends }\end{array}$ & $\mathrm{n} / \mathrm{a}$ & 1 & \multirow{9}{*}{0} & \multirow{9}{*}{$\mathrm{n} / \mathrm{a}$} & \multirow{9}{*}{0} & \multirow{9}{*}{1.0} \\
\hline & Instrumental motives - can go out & $\mathrm{n} / \mathrm{a}$ & 1 & & & & \\
\hline & $\begin{array}{l}\text { Independent motives - free to stop } \\
\text { everywhere }\end{array}$ & $\mathrm{n} / \mathrm{a}$ & 1 & & & & \\
\hline & Independent motives - chose own route & $\mathrm{n} / \mathrm{a}$ & 1 & & & & \\
\hline & $\begin{array}{l}\text { Instrumental motives - makes life more } \\
\text { easy }\end{array}$ & $\mathrm{n} / \mathrm{a}$ & 1 & & & & \\
\hline & $\begin{array}{l}\text { Independent motives - not dependent on } \\
\text { others }\end{array}$ & $\mathrm{n} / \mathrm{a}$ & 1 & & & & \\
\hline & $\begin{array}{l}\text { Independent motives - brings wherever I } \\
\text { want }\end{array}$ & $\mathrm{n} / \mathrm{a}$ & 1 & & & & \\
\hline & Instrumental motives - comfortable & $\mathrm{n} / \mathrm{a}$ & 1 & & & & \\
\hline & Independent motives - freedom & $\mathrm{n} / \mathrm{a}$ & 1 & & & & \\
\hline
\end{tabular}




\begin{tabular}{|c|c|c|c|c|c|c|c|}
\hline \multirow[b]{2}{*}{ Author(s) (year) } & \multirow[b]{2}{*}{ Cognitive Mechanism(s) } & \multicolumn{6}{|c|}{ Indicators of Study Quality } \\
\hline & & reliable & valid & $\begin{array}{l}\text { Large } \\
\text { sample } \\
\text { (Power } \\
\text { Analysis) }\end{array}$ & $\begin{array}{l}\text { Large } \\
\text { Sample } \\
\text { (SEM/Path } \\
=>200 \text { ) }\end{array}$ & $\begin{array}{l}\text { Repres } \\
\text { entativ } \\
\text { eness }\end{array}$ & $\begin{array}{l}\text { Total } \\
\text { Score }\end{array}$ \\
\hline & Independent motives - time saving & $\mathrm{n} / \mathrm{a}$ & 1 & & & & \\
\hline & $\begin{array}{l}\text { Instrumental motives - Protection against } \\
\text { bad weather }\end{array}$ & $\mathrm{n} / \mathrm{a}$ & 1 & & & & \\
\hline & $\begin{array}{l}\text { Independent motives - car always } \\
\text { available }\end{array}$ & $\mathrm{n} / \mathrm{a}$ & 1 & & & & \\
\hline & Instrumental motives - good road holding & $\mathrm{n} / \mathrm{a}$ & 1 & & & & \\
\hline & Instrumental motives - Safe in car & $\mathrm{n} / \mathrm{a}$ & 1 & & & & \\
\hline & $\begin{array}{l}\text { Instrumental motives - enables holiday } \\
\text { trips }\end{array}$ & $\mathrm{n} / \mathrm{a}$ & 1 & & & & \\
\hline \multirow{11}{*}{$\begin{array}{l}\text { Cao \& Mokhtarian } \\
(2005)\end{array}$} & Attitudes - Pro-environmental & 0 & 0 & \multirow{11}{*}{0} & \multirow{11}{*}{$\mathrm{n} / \mathrm{a}$} & \multirow{11}{*}{1} & \multirow{11}{*}{1.0} \\
\hline & Personality - Calm & 0 & 0 & & & & \\
\hline & Personality - Loner & 0 & 0 & & & & \\
\hline & Attitude - Commute benefit & 0 & 0 & & & & \\
\hline & Attitude - Travel stress & 0 & 0 & & & & \\
\hline & Attitude - Pro-hi density & 0 & 0 & & & & \\
\hline & Personality - Adventure seeking & 0 & 0 & & & & \\
\hline & Lifestyle - Frustrated & 0 & 0 & & & & \\
\hline & $\begin{array}{l}\text { Lifestyle - Family and community } \\
\text { oriented }\end{array}$ & 0 & 0 & & & & \\
\hline & Lifestyle - Status seeker & 0 & 0 & & & & \\
\hline & Lifestyle - Workaholic & 0 & 0 & & & & \\
\hline \multirow{4}{*}{$\begin{array}{l}\text { Collins \& Chambers } \\
\text { (2005) }\end{array}$} & Social values - Environment & 1 & 1 & \multirow{4}{*}{0} & \multirow{4}{*}{$\mathrm{n} / \mathrm{a}$} & \multirow{4}{*}{0} & \multirow{4}{*}{0.9} \\
\hline & Biospheric values - Environment & 1 & 1 & & & & \\
\hline & Egoistic values - Environment & 1 & 1 & & & & \\
\hline & $\begin{array}{l}\text { Social beliefs - Environmental threat of } \\
\text { cars }\end{array}$ & 0 & 1 & & & & \\
\hline
\end{tabular}




\begin{tabular}{|c|c|c|c|c|c|c|c|}
\hline \multirow[b]{2}{*}{ Author(s) (year) } & \multirow[b]{2}{*}{ Cognitive Mechanism(s) } & \multicolumn{6}{|c|}{ Indicators of Study Quality } \\
\hline & & reliable & valid & $\begin{array}{l}\text { Large } \\
\text { sample } \\
\text { (Power } \\
\text { Analysis) }\end{array}$ & $\begin{array}{l}\text { Large } \\
\text { Sample } \\
\text { (SEM/Path } \\
=>200 \text { ) }\end{array}$ & $\begin{array}{l}\text { Repres } \\
\text { entativ } \\
\text { eness }\end{array}$ & $\begin{array}{l}\text { Total } \\
\text { Score }\end{array}$ \\
\hline & $\begin{array}{l}\text { Control beliefs (perceived) - } \\
\text { environmental threat of cars }\end{array}$ & 1 & 1 & & & & \\
\hline & $\begin{array}{l}\text { Egoistic beliefs - environmental threat of } \\
\text { cars }\end{array}$ & 1 & 1 & & & & \\
\hline & $\begin{array}{l}\text { Biospheric beliefs - environmental threat } \\
\text { of cars }\end{array}$ & 0 & 1 & & & & \\
\hline & $\begin{array}{l}\text { Consideration of future consequences - } \\
\text { Environment }\end{array}$ & 1 & 1 & & & & \\
\hline Davidov (2007) & Habit - PT use & 0 & 1 & 0 & $\mathrm{n} / \mathrm{a}$ & 0 & 0.5 \\
\hline \multirow{5}{*}{$\begin{array}{l}\text { Friedrichsmeier et al. } \\
\text { (2013) }\end{array}$} & Habit - Past behaviour & 0 & 1 & \multirow{5}{*}{0} & \multirow{5}{*}{$\mathrm{n} / \mathrm{a}$} & \multirow{5}{*}{0} & \multirow{5}{*}{0.3} \\
\hline & Intention - Car use & 0 & 0 & & & & \\
\hline & Habit Strength & 0 & 0 & & & & \\
\hline & Habit - RFM & 0 & 1 & & & & \\
\hline & Habit - Context stability & 0 & 1 & & & & \\
\hline \multirow{2}{*}{ Gardner (2009) } & Habit & 1 & 1 & \multirow{2}{*}{1} & \multirow{2}{*}{$\mathrm{n} / \mathrm{a}$} & \multirow{2}{*}{0} & \multirow{2}{*}{1.8} \\
\hline & Intention - Car use & 1 & 0 & & & & \\
\hline \multirow{11}{*}{$\begin{array}{l}\text { Gardner \& Abraham } \\
\text { (2010) }\end{array}$} & Intention - Car use & 1 & 1 & \multirow{11}{*}{1} & \multirow{11}{*}{$\mathrm{n} / \mathrm{a}$} & \multirow{11}{*}{0} & \multirow{11}{*}{2.0} \\
\hline & PBC - Environmental problem reduction & 1 & 1 & & & & \\
\hline & Environmental concern & 1 & 1 & & & & \\
\hline & Attitude - Non-car use & 1 & 1 & & & & \\
\hline & PBC - Car use & 1 & 1 & & & & \\
\hline & Attitude - Car use & 1 & 1 & & & & \\
\hline & SN - Non-car use & 1 & 1 & & & & \\
\hline & Descriptive norm - Car use & 1 & 1 & & & & \\
\hline & SN - Car use & 1 & 1 & & & & \\
\hline & PBC - Non-car use & 1 & 1 & & & & \\
\hline & PN - Non-car use & 1 & 1 & & & & \\
\hline
\end{tabular}




\begin{tabular}{|c|c|c|c|c|c|c|c|}
\hline \multirow[b]{2}{*}{ Author(s) (year) } & \multirow[b]{2}{*}{ Cognitive Mechanism(s) } & \multicolumn{6}{|c|}{ Indicators of Study Quality } \\
\hline & & reliable & valid & $\begin{array}{l}\text { Large } \\
\text { sample } \\
\text { (Power } \\
\text { Analysis) }\end{array}$ & $\begin{array}{l}\text { Large } \\
\text { Sample } \\
(\mathrm{SEM} / \text { Path } \\
=>200)\end{array}$ & $\begin{array}{l}\text { Repres } \\
\text { entativ } \\
\text { eness }\end{array}$ & $\begin{array}{l}\text { Total } \\
\text { Score }\end{array}$ \\
\hline & Environmental problem awareness & 1 & 1 & & & & \\
\hline \multirow{2}{*}{ Gärling et al. (2001) } & Attitude - Car use & 1 & 0 & \multirow{2}{*}{$\mathrm{n} / \mathrm{a}$} & \multirow{2}{*}{0} & \multirow{2}{*}{0} & \multirow{2}{*}{0.8} \\
\hline & Habit - Script-based driving frequency & 1 & 1 & & & & \\
\hline \multirow{4}{*}{$\begin{array}{l}\text { Golob \& Hensher } \\
\text { (1998) }\end{array}$} & $\begin{array}{l}\text { Attitudes - Traffic congestion is not so bad } \\
\text { [ordinal] }\end{array}$ & $\mathrm{n} / \mathrm{a}$ & 0 & \multirow{4}{*}{$\mathrm{n} / \mathrm{a}$} & \multirow{4}{*}{1} & \multirow{4}{*}{0} & \multirow{4}{*}{1.0} \\
\hline & Attitudes - Car as status symbol [ordinal] & $\mathrm{n} / \mathrm{a}$ & 0 & & & & \\
\hline & $\begin{array}{l}\text { Attitudes - GGE abatement is possible } \\
\text { [ordinal] }\end{array}$ & $\mathrm{n} / \mathrm{a}$ & 0 & & & & \\
\hline & $\begin{array}{l}\text { Attitudes - GGE is a serious threat } \\
\text { [ordinal] }\end{array}$ & $\mathrm{n} / \mathrm{a}$ & 0 & & & & \\
\hline \multirow{6}{*}{ Harland et al. (1999) } & PN - Non-car use & 1 & 1 & \multirow{6}{*}{0} & \multirow{6}{*}{$\mathrm{n} / \mathrm{a}$} & \multirow{6}{*}{0} & \multirow{6}{*}{0.8} \\
\hline & Intention - Non-car use & $\mathrm{n} / \mathrm{a}$ & 0 & & & & \\
\hline & PBC - Non-car use & $\mathrm{n} / \mathrm{a}$ & 1 & & & & \\
\hline & Attitude - Non-car use & $\mathrm{n} / \mathrm{a}$ & 1 & & & & \\
\hline & $\begin{array}{l}\text { Environmental Involvement (awareness of } \\
\text { consequences) }\end{array}$ & 1 & 0 & & & & \\
\hline & SN - Non-car use & $\mathrm{n} / \mathrm{a}$ & 1 & & & & \\
\hline \multirow{10}{*}{$\begin{array}{l}\text { Haustein \& Hunecke } \\
\text { (2007) }\end{array}$} & Intention1 - PT vs car & $\mathrm{n} / \mathrm{a}$ & 1 & \multirow{10}{*}{$\mathrm{n} / \mathrm{a}$} & \multirow{10}{*}{1} & \multirow{10}{*}{1} & \multirow{10}{*}{3.0} \\
\hline & Intention2 - PT vs car & $\mathrm{n} / \mathrm{a}$ & 1 & & & & \\
\hline & PBC1 - PT vs car & $\mathrm{n} / \mathrm{a}$ & 1 & & & & \\
\hline & PBC2 - PT vs car & $\mathrm{n} / \mathrm{a}$ & 1 & & & & \\
\hline & SN1 - PT vs car & $\mathrm{n} / \mathrm{a}$ & 1 & & & & \\
\hline & SN2 - PT vs car & $\mathrm{n} / \mathrm{a}$ & 1 & & & & \\
\hline & Attitude - Car autonomy & $\mathrm{n} / \mathrm{a}$ & 1 & & & & \\
\hline & Attitude - Car excitement & $\mathrm{n} / \mathrm{a}$ & 1 & & & & \\
\hline & Attitude - Car competence 1 & $\mathrm{n} / \mathrm{a}$ & 1 & & & & \\
\hline & Attitude - Car competence 1 & $\mathrm{n} / \mathrm{a}$ & 1 & & & & \\
\hline
\end{tabular}




\begin{tabular}{|c|c|c|c|c|c|c|c|}
\hline \multirow[b]{2}{*}{ Author(s) (year) } & \multirow[b]{2}{*}{ Cognitive Mechanism(s) } & \multicolumn{6}{|c|}{ Indicators of Study Quality } \\
\hline & & reliable & valid & $\begin{array}{l}\text { Large } \\
\text { sample } \\
\text { (Power } \\
\text { Analysis) }\end{array}$ & $\begin{array}{l}\text { Large } \\
\text { Sample } \\
\text { (SEM/Path } \\
=>200 \text { ) }\end{array}$ & $\begin{array}{l}\text { Repres } \\
\text { entativ } \\
\text { eness }\end{array}$ & $\begin{array}{l}\text { Total } \\
\text { Score }\end{array}$ \\
\hline & Attitude - PT excitement 1 & $\mathrm{n} / \mathrm{a}$ & 1 & & & & \\
\hline & Attitude - PT excitement 2 & $\mathrm{n} / \mathrm{a}$ & 1 & & & & \\
\hline & Attitude - Bicycle excitement & $\mathrm{n} / \mathrm{a}$ & 1 & & & & \\
\hline & Attitude - Bicycle autonomy & $\mathrm{n} / \mathrm{a}$ & 1 & & & & \\
\hline & Perceived mobility necessity 1 & $\mathrm{n} / \mathrm{a}$ & 1 & & & & \\
\hline & Perceived mobility necessity 2 & $\mathrm{n} / \mathrm{a}$ & 1 & & & & \\
\hline \multirow{6}{*}{ Hunecke et al. (2001) } & $\begin{array}{l}\text { Perception of ecological problem - Car } \\
\text { use }\end{array}$ & 1 & 1 & \multirow{6}{*}{0} & \multirow{6}{*}{$\mathrm{n} / \mathrm{a}$} & \multirow{6}{*}{0} & \multirow{6}{*}{0.9} \\
\hline & PBC - Subway use & 0 & 1 & & & & \\
\hline & Personal ecological norm & 1 & 1 & & & & \\
\hline & SN - Subway vs car & 1 & 1 & & & & \\
\hline & Feelings of ecological guilt - car use & 1 & 1 & & & & \\
\hline & Awareness of consequences - car use & 1 & 1 & & & & \\
\hline \multirow{4}{*}{ Hunecke et al. (2007) } & Values - Conservation & 1 & 1 & \multirow{4}{*}{0} & \multirow{4}{*}{$\mathrm{n} / \mathrm{a}$} & \multirow{4}{*}{1} & \multirow{4}{*}{2.0} \\
\hline & Values - Self-transcendence & 1 & 1 & & & & \\
\hline & Values - Openness to change & 1 & 1 & & & & \\
\hline & Values - Self-enhancement & 1 & 1 & & & & \\
\hline \multirow{5}{*}{ Joireman et al. (1997) } & Concern - Comfort & $\mathrm{n} / \mathrm{a}$ & 0 & \multirow{5}{*}{0} & \multirow{5}{*}{$\mathrm{n} / \mathrm{a}$} & \multirow{5}{*}{0} & \multirow{5}{*}{0.0} \\
\hline & Concern - Travel time & $\mathrm{n} / \mathrm{a}$ & 0 & & & & \\
\hline & Concern - Flexibility & $\mathrm{n} / \mathrm{a}$ & 0 & & & & \\
\hline & Concern - Environment & $\mathrm{n} / \mathrm{a}$ & 0 & & & & \\
\hline & Concern - Public Health & $\mathrm{n} / \mathrm{a}$ & 0 & & & & \\
\hline \multirow{5}{*}{$\begin{array}{l}\text { Kaiser \& Gutscher } \\
\text { (2003) }\end{array}$} & Intention - Non-car use & 1 & 1 & \multirow{5}{*}{0} & \multirow{5}{*}{$\mathrm{n} / \mathrm{a}$} & \multirow{5}{*}{0} & \multirow{5}{*}{1.0} \\
\hline & PBC - Non-car use & 1 & 1 & & & & \\
\hline & Attitude - Non-car use & 1 & 1 & & & & \\
\hline & Descriptive norm - Car use & $\mathrm{n} / \mathrm{a}$ & 1 & & & & \\
\hline & SN - Non-car use & $\mathrm{n} / \mathrm{a}$ & 1 & & & & \\
\hline
\end{tabular}




\begin{tabular}{|c|c|c|c|c|c|c|c|}
\hline \multirow[b]{2}{*}{ Author(s) (year) } & \multirow[b]{2}{*}{ Cognitive Mechanism(s) } & \multicolumn{6}{|c|}{ Indicators of Study Quality } \\
\hline & & reliable & valid & $\begin{array}{l}\text { Large } \\
\text { sample } \\
\text { (Power } \\
\text { Analysis) }\end{array}$ & $\begin{array}{l}\text { Large } \\
\text { Sample } \\
\text { (SEM/Path } \\
=>200)\end{array}$ & $\begin{array}{l}\text { Repres } \\
\text { entativ } \\
\text { eness }\end{array}$ & $\begin{array}{l}\text { Total } \\
\text { Score }\end{array}$ \\
\hline \multirow{5}{*}{ Kerr et al. (2010) } & Intention - Car use & 1 & 1 & \multirow{5}{*}{0} & \multirow{5}{*}{$\mathrm{n} / \mathrm{a}$} & \multirow{5}{*}{0} & \multirow{5}{*}{1.0} \\
\hline & Habit & $\mathrm{n} / \mathrm{a}$ & 1 & & & & \\
\hline & SN - Car use & 1 & 1 & & & & \\
\hline & $\begin{array}{l}\text { Attitude - Car use, convenience, } \\
\text { reliability, comfort, security, pleasantness }\end{array}$ & 1 & 1 & & & & \\
\hline & PBC - Car use & 1 & 1 & & & & \\
\hline \multirow{7}{*}{$\begin{array}{l}\text { Klöckner \& Blöbaum } \\
\text { (2010) }\end{array}$} & Ecological Intention - PT vs car & 1 & 1 & \multirow{7}{*}{$\mathrm{n} / \mathrm{a}$} & \multirow{7}{*}{1} & \multirow{7}{*}{0} & \multirow{7}{*}{2.0} \\
\hline & $\mathrm{PBC}$ & 1 & 1 & & & & \\
\hline & Habit - Car choice & 1 & 1 & & & & \\
\hline & Personal Ecological Norm & 1 & 1 & & & & \\
\hline & Social Ecological Norm & 1 & 1 & & & & \\
\hline & Awareness of need & 1 & 1 & & & & \\
\hline & Awareness of consequences & 1 & 1 & & & & \\
\hline \multirow{3}{*}{$\begin{array}{l}\text { Klöckner \& Matthies } \\
\text { (2004) }\end{array}$} & PN - non-Car use & 1 & 0 & \multirow{3}{*}{0} & \multirow{3}{*}{$\mathrm{n} / \mathrm{a}$} & \multirow{3}{*}{0} & \multirow{3}{*}{0.6} \\
\hline & SN & 1 & 0 & & & & \\
\hline & Habit - Car choice & $\mathrm{n} / \mathrm{a}$ & 1 & & & & \\
\hline \multirow{6}{*}{$\begin{array}{l}\text { Lois \& Lopez-Saez } \\
\text { (2009) }\end{array}$} & $\begin{array}{l}\text { Symbolic motivations - Car use } \\
\text { (Shopping) }\end{array}$ & 1 & 1 & \multirow{6}{*}{$\mathrm{n} / \mathrm{a}$} & \multirow{6}{*}{1} & \multirow{6}{*}{0} & \multirow{6}{*}{2.0} \\
\hline & $\begin{array}{l}\text { Instrumental motivations - Car use } \\
\text { (Shopping) }\end{array}$ & 1 & 1 & & & & \\
\hline & $\begin{array}{l}\text { Symbolic motivations - Car use (visiting } \\
\text { friends/family) }\end{array}$ & 1 & 1 & & & & \\
\hline & $\begin{array}{l}\text { Instrumental motivations - Car use } \\
\text { (visiting friends/family) }\end{array}$ & 1 & 1 & & & & \\
\hline & $\begin{array}{l}\text { Symbolic motivations - Car use } \\
\text { (commuting) }\end{array}$ & 1 & 1 & & & & \\
\hline & Instrumental motivations - Car use & 1 & 1 & & & & \\
\hline
\end{tabular}




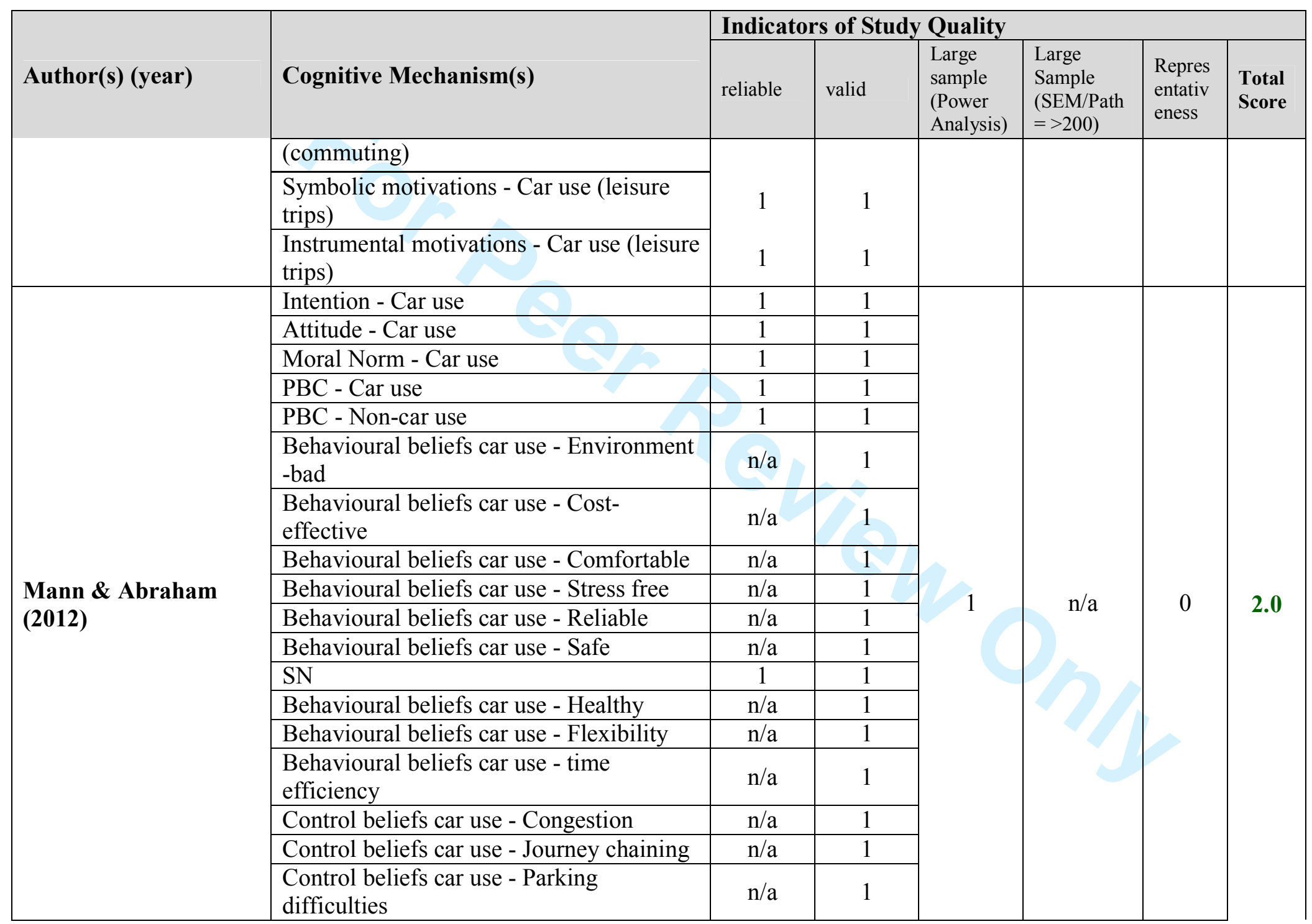




\begin{tabular}{|c|c|c|c|c|c|c|c|}
\hline \multirow[b]{2}{*}{ Author(s) (year) } & \multirow[b]{2}{*}{ Cognitive Mechanism(s) } & \multicolumn{6}{|c|}{ Indicators of Study Quality } \\
\hline & & reliable & valid & $\begin{array}{l}\text { Large } \\
\text { sample } \\
\text { (Power } \\
\text { Analysis) }\end{array}$ & $\begin{array}{l}\text { Large } \\
\text { Sample } \\
\text { (SEM/Path } \\
=>200 \text { ) }\end{array}$ & $\begin{array}{l}\text { Repres } \\
\text { entativ } \\
\text { eness }\end{array}$ & $\begin{array}{l}\text { Total } \\
\text { Score }\end{array}$ \\
\hline & Control beliefs car use - Accident risk & $\mathrm{n} / \mathrm{a}$ & 1 & \multirow{6}{*}{0} & \multirow{6}{*}{$\mathrm{n} / \mathrm{a}$} & \multirow{6}{*}{0} & \multirow{6}{*}{0.3} \\
\hline & Descriptive norm - Car use & $\mathrm{n} / \mathrm{a}$ & 0 & & & & \\
\hline \multirow{4}{*}{ Matthies et al. (2006) } & Perceived Behavioural Costs - PT vs Car & 0 & 0 & & & & \\
\hline & PN - Car use reduction & 1 & 0 & & & & \\
\hline & Habit & $\mathrm{n} / \mathrm{a}$ & 1 & & & & \\
\hline & SN - PT vs car & 0 & 0 & & & & \\
\hline \multirow{13}{*}{ Murtagh et al. (2012) } & Social identity - Parent (Commuting) & $\mathrm{n} / \mathrm{a}$ & 1 & \multirow{13}{*}{1} & \multirow{13}{*}{$\mathrm{n} / \mathrm{a}$} & \multirow{13}{*}{1} & \multirow{13}{*}{3.0} \\
\hline & $\begin{array}{l}\text { Transport identity - Motorist } \\
\text { (Commuting) }\end{array}$ & $\mathrm{n} / \mathrm{a}$ & 1 & & & & \\
\hline & Social identity - Worker (Commuting) & $\mathrm{n} / \mathrm{a}$ & 1 & & & & \\
\hline & Transport identity - PT user (Commuting) & $\mathrm{n} / \mathrm{a}$ & 1 & & & & \\
\hline & $\begin{array}{l}\text { Transport identity - Pedestrian } \\
\text { (Commuting) }\end{array}$ & $\mathrm{n} / \mathrm{a}$ & 1 & & & & \\
\hline & Transport identity - Cyclist (Commuting) & $\mathrm{n} / \mathrm{a}$ & 1 & & & & \\
\hline & $\begin{array}{l}\text { Social identity - Member of local } \\
\text { community (Commuting) }\end{array}$ & $\mathrm{n} / \mathrm{a}$ & 1 & & & & \\
\hline & Social identity - Parent (General Purpose) & $\mathrm{n} / \mathrm{a}$ & 1 & & & & \\
\hline & $\begin{array}{l}\text { Transport identity - Motorist (General } \\
\text { Purpose) }\end{array}$ & $\mathrm{n} / \mathrm{a}$ & 1 & & & & \\
\hline & $\begin{array}{l}\text { Social identity - Worker (General } \\
\text { Purpose) }\end{array}$ & $\mathrm{n} / \mathrm{a}$ & 1 & & & & \\
\hline & $\begin{array}{l}\text { Transport identity - PT user (General } \\
\text { Purpose) }\end{array}$ & $\mathrm{n} / \mathrm{a}$ & 1 & & & & \\
\hline & $\begin{array}{l}\text { Transport identity - Pedestrian (General } \\
\text { Purpose) }\end{array}$ & $\mathrm{n} / \mathrm{a}$ & 1 & & & & \\
\hline & $\begin{array}{l}\text { Transport identity - Cyclist (General } \\
\text { Purpose) }\end{array}$ & $\mathrm{n} / \mathrm{a}$ & 1 & & & & \\
\hline
\end{tabular}




\begin{tabular}{|c|c|c|c|c|c|c|c|}
\hline \multirow[b]{2}{*}{ Author(s) (year) } & \multirow[b]{2}{*}{ Cognitive Mechanism(s) } & \multicolumn{6}{|c|}{ Indicators of Study Quality } \\
\hline & & reliable & valid & $\begin{array}{l}\text { Large } \\
\text { sample } \\
\text { (Power } \\
\text { Analysis) }\end{array}$ & $\begin{array}{l}\text { Large } \\
\text { Sample } \\
(\text { SEM/Path } \\
=>200)\end{array}$ & $\begin{array}{l}\text { Repres } \\
\text { entativ } \\
\text { eness }\end{array}$ & $\begin{array}{l}\text { Total } \\
\text { Score }\end{array}$ \\
\hline & $\begin{array}{l}\text { Social identity - Member of local } \\
\text { community (General Purpose) }\end{array}$ & $\mathrm{n} / \mathrm{a}$ & 1 & & & & \\
\hline \multirow{6}{*}{$\begin{array}{l}\text { Nilsson \& Küller } \\
(2000)\end{array}$} & Attitudes - PT & 0 & 1 & \multirow{6}{*}{0} & \multirow{6}{*}{$\mathrm{n} / \mathrm{a}$} & \multirow{6}{*}{0} & \multirow{6}{*}{0.7} \\
\hline & Attitudes - hazard/efficacy & 1 & 1 & & & & \\
\hline & Attitudes - Personal concern & 0 & 1 & & & & \\
\hline & Attitudes - Car affection & 1 & 1 & & & & \\
\hline & Attitudes - Environmental concern & 0 & 1 & & & & \\
\hline & Environmental Knowledge & 0 & 1 & & & & \\
\hline \multirow{12}{*}{ Panter et al. (2013) } & Intention - Car use & 0 & 1 & \multirow{12}{*}{0} & \multirow{12}{*}{$\mathrm{n} / \mathrm{a}$} & \multirow{12}{*}{0} & \multirow{12}{*}{0.7} \\
\hline & Attitude - Car use & 0 & 1 & & & & \\
\hline & PBC - Car use & 0 & 1 & & & & \\
\hline & Social Norm - Car use & 0 & 1 & & & & \\
\hline & Habits & 0 & 1 & & & & \\
\hline & $\begin{array}{l}\text { Perceptions of route environment - } \\
\text { pleasant to walk }\end{array}$ & $\mathrm{n} / \mathrm{a}$ & 1 & & & & \\
\hline & $\begin{array}{l}\text { Perceptions of route environment - } \\
\text { dangerous to cycle }\end{array}$ & $\mathrm{n} / \mathrm{a}$ & 1 & & & & \\
\hline & $\begin{array}{l}\text { Perceptions of route environment - } \\
\text { convenient to cycle }\end{array}$ & $\mathrm{n} / \mathrm{a}$ & 1 & & & & \\
\hline & $\begin{array}{l}\text { Perceptions of route environment - little } \\
\text { traffic }\end{array}$ & $\mathrm{n} / \mathrm{a}$ & 1 & & & & \\
\hline & $\begin{array}{l}\text { Perceptions of route environment - } \\
\text { convenient PT }\end{array}$ & $\mathrm{n} / \mathrm{a}$ & 1 & & & & \\
\hline & $\begin{array}{l}\text { Perceptions of route environment - no } \\
\text { convenient routes for walking }\end{array}$ & $\mathrm{n} / \mathrm{a}$ & 1 & & & & \\
\hline & $\begin{array}{l}\text { Perceptions of route environment - safe to } \\
\text { cross the road }\end{array}$ & $\mathrm{n} / \mathrm{a}$ & 1 & & & & \\
\hline
\end{tabular}




\begin{tabular}{|c|c|c|c|c|c|c|c|}
\hline \multirow[b]{2}{*}{ Author(s) (year) } & \multirow[b]{2}{*}{ Cognitive Mechanism(s) } & \multicolumn{6}{|c|}{ Indicators of Study Quality } \\
\hline & & reliable & valid & $\begin{array}{l}\text { Large } \\
\text { sample } \\
\text { (Power } \\
\text { Analysis) }\end{array}$ & $\begin{array}{l}\text { Large } \\
\text { Sample } \\
(\text { SEM/Path } \\
=>200)\end{array}$ & $\begin{array}{l}\text { Repres } \\
\text { entativ } \\
\text { eness }\end{array}$ & $\begin{array}{l}\text { Total } \\
\text { Score }\end{array}$ \\
\hline \multirow{5}{*}{ Polk (2003) } & $\begin{array}{l}\text { Attitudes - Positive evaluation of } \\
\text { automobility }\end{array}$ & $\mathrm{n} / \mathrm{a}$ & 1 & \multirow{5}{*}{0} & \multirow{5}{*}{$\mathrm{n} / \mathrm{a}$} & \multirow{5}{*}{0} & \multirow{5}{*}{1.0} \\
\hline & $\begin{array}{l}\text { Attitudes - Automobility as a cause of } \\
\text { environmental problems }\end{array}$ & 1 & 1 & & & & \\
\hline & $\begin{array}{l}\text { Attitudes - Negative evaluation of } \\
\text { automobility }\end{array}$ & $\mathrm{n} / \mathrm{a}$ & 1 & & & & \\
\hline & $\begin{array}{l}\text { Attitudes - Opinions of specific proposals } \\
\text { to reduce car use }\end{array}$ & $\mathrm{n} / \mathrm{a}$ & 1 & & & & \\
\hline & Attitudes - Environmental Concern & 1 & 1 & & & & \\
\hline \multirow{8}{*}{$\begin{array}{l}\text { Scheiner \& Holz-Rau } \\
\text { (2007) }\end{array}$} & $\begin{array}{l}\text { Location attitudes - Subjective importance } \\
\text { PT }\end{array}$ & $\mathrm{n} / \mathrm{a}$ & 0 & \multirow{8}{*}{$\mathrm{n} / \mathrm{a}$} & \multirow{8}{*}{1} & \multirow{8}{*}{0} & \multirow{8}{*}{1.0} \\
\hline & $\begin{array}{l}\text { Location attitudes - Subjective importance } \\
\text { shopping/services }\end{array}$ & $\mathrm{n} / \mathrm{a}$ & 0 & & & & \\
\hline & $\begin{array}{l}\text { Location attitudes - Subjective importance } \\
\text { access to centre }\end{array}$ & $\mathrm{n} / \mathrm{a}$ & 0 & & & & \\
\hline & Lifestyle - Out of home self-realisation & 0 & 0 & & & & \\
\hline & $\begin{array}{l}\text { Location attitudes - Subjective importance } \\
\text { PT }\end{array}$ & $\mathrm{n} / \mathrm{a}$ & 0 & & & & \\
\hline & $\begin{array}{l}\text { Location attitudes - Subjective importance } \\
\text { shopping/services }\end{array}$ & $\mathrm{n} / \mathrm{a}$ & 0 & & & & \\
\hline & $\begin{array}{l}\text { Location attitudes - Subjective importance } \\
\text { access to centre }\end{array}$ & $\mathrm{n} / \mathrm{a}$ & 0 & & & & \\
\hline & Lifestyle - Out of home self-realisation & 0 & 0 & & & & \\
\hline \multirow[b]{2}{*}{ Steg (2005) } & Symbolic motives - Descriptive norm & 1 & 1 & \multirow[b]{2}{*}{0} & \multirow[b]{2}{*}{$\mathrm{n} / \mathrm{a}$} & \multirow[b]{2}{*}{1} & \multirow[b]{2}{*}{2.0} \\
\hline & $\begin{array}{l}\text { Symbolic motives - Social comparison } \\
\text { and self-presentation }\end{array}$ & 1 & 1 & & & & \\
\hline
\end{tabular}




\begin{tabular}{|c|c|c|c|c|c|c|c|}
\hline \multirow[b]{2}{*}{ Author(s) (year) } & \multirow[b]{2}{*}{ Cognitive Mechanism(s) } & \multicolumn{6}{|c|}{ Indicators of Study Quality } \\
\hline & & reliable & valid & $\begin{array}{l}\text { Large } \\
\text { sample } \\
\text { (Power } \\
\text { Analysis) }\end{array}$ & $\begin{array}{l}\text { Large } \\
\text { Sample } \\
(\text { SEM/Path } \\
=>200)\end{array}$ & $\begin{array}{l}\text { Repres } \\
\text { entativ } \\
\text { eness }\end{array}$ & $\begin{array}{l}\text { Total } \\
\text { Score }\end{array}$ \\
\hline & $\begin{array}{l}\text { Symbolic motives - SN (expectations } \\
\text { family) }\end{array}$ & $\mathrm{n} / \mathrm{a}$ & 1 & & & & \\
\hline & $\begin{array}{l}\text { Instrumental motives - Attitudes car } \\
\text { commute }(8)\end{array}$ & 1 & 1 & & & & \\
\hline \multirow{3}{*}{ Steg \& Sievers (2000) } & $\begin{array}{l}\text { Environmental beliefs - Problem } \\
\text { awareness }\end{array}$ & 1 & 0 & \multirow{3}{*}{0} & \multirow{3}{*}{$\mathrm{n} / \mathrm{a}$} & \multirow{3}{*}{0} & \multirow{3}{*}{0.5} \\
\hline & Environmental beliefs - Efforts useful & 1 & 0 & & & & \\
\hline & Environmental beliefs - responsibility & 1 & 0 & & & & \\
\hline \multirow{5}{*}{ Tanner (1999) } & $\begin{array}{l}\text { Subjective constraints - Perceived } \\
\text { behavioural barriers (car use reduction) }\end{array}$ & $\mathrm{n} / \mathrm{a}$ & 1 & \multirow{5}{*}{0} & \multirow{5}{*}{$\mathrm{n} / \mathrm{a}$} & \multirow{5}{*}{0} & \multirow{5}{*}{1.0} \\
\hline & $\begin{array}{l}\text { Subjective constraints - Sense of } \\
\text { responsibility (preservation of } \\
\text { environment) }\end{array}$ & $\mathrm{n} / \mathrm{a}$ & 1 & & & & \\
\hline & $\begin{array}{l}\text { Biospheric values - General problem } \\
\text { awareness }\end{array}$ & 1 & 1 & & & & \\
\hline & $\begin{array}{l}\text { Egoistic values - Personal problem } \\
\text { awareness (environment) }\end{array}$ & 1 & 1 & & & & \\
\hline & $\begin{array}{l}\text { Perceived efficacy (change in } \\
\text { environmental degradation) }\end{array}$ & 1 & 1 & & & & \\
\hline $\begin{array}{l}\text { Tischer \& Phillips } \\
\text { (1979) }\end{array}$ & Beliefs - Car use attributes (18) & 0 & 0 & 0 & $\mathrm{n} / \mathrm{a}$ & 0 & 0.0 \\
\hline \multirow{4}{*}{ van Acker et al. (2011) } & Travel attitudes - Pro-environment & 0 & 1 & \multirow{4}{*}{$\mathrm{n} / \mathrm{a}$} & \multirow{4}{*}{1} & \multirow{4}{*}{0} & \multirow{4}{*}{1.5} \\
\hline & $\begin{array}{l}\text { Lifestyle - Home-oriented traditional } \\
\text { family }\end{array}$ & 0 & 1 & & & & \\
\hline & Lifestyle - Culture lover & 0 & 1 & & & & \\
\hline & $\begin{array}{l}\text { Residential attitudes - Open space and } \\
\text { quietness }\end{array}$ & 0 & 1 & & & & \\
\hline
\end{tabular}




\begin{tabular}{|c|c|c|c|c|c|c|c|}
\hline \multirow[b]{2}{*}{ Author(s) (year) } & \multirow[b]{2}{*}{ Cognitive Mechanism(s) } & \multicolumn{6}{|c|}{ Indicators of Study Quality } \\
\hline & & reliable & valid & $\begin{array}{l}\text { Large } \\
\text { sample } \\
\text { (Power } \\
\text { Analysis) }\end{array}$ & $\begin{array}{l}\text { Large } \\
\text { Sample } \\
\text { (SEM/Path } \\
=>200)\end{array}$ & $\begin{array}{l}\text { Repres } \\
\text { entativ } \\
\text { eness }\end{array}$ & $\begin{array}{l}\text { Total } \\
\text { Score }\end{array}$ \\
\hline & $\begin{array}{l}\text { Travel mode attitudes - bike/on foot }= \\
\text { positive effects }\end{array}$ & 0 & 1 & & & & \\
\hline & $\begin{array}{l}\text { Travel mode attitudes }- \text { bike/on foot }= \\
\text { comfortable }\end{array}$ & 0 & 1 & & & & \\
\hline & $\begin{array}{l}\text { Travel mode attitudes }- \text { Car }=\text { negative } \\
\text { effects }\end{array}$ & 0 & 1 & & & & \\
\hline & Travel mode attitudes - Car $=$ comfortable & 0 & 1 & & & & \\
\hline & $\begin{array}{l}\text { Lifestyle - Home-oriented but active } \\
\text { family }\end{array}$ & 0 & 1 & & & & \\
\hline & Residential attitude - Car alternatives & 0 & 1 & & & & \\
\hline & Lifestyle - Friends \& trends & 0 & 1 & & & & \\
\hline & Residential attitude - Accessibility & 0 & 1 & & & & \\
\hline & Travel mode attitudes $-\mathrm{PT}=$ comfortable & 0 & 1 & & & & \\
\hline & Travel mode attitudes $-\mathrm{PT}=$ time-saving & 0 & 1 & & & & \\
\hline & $\begin{array}{l}\text { Travel mode attitudes - PT = positive } \\
\text { effects }\end{array}$ & 0 & 1 & & & & \\
\hline & $\begin{array}{l}\text { Travel attitudes - Reduced driving social } \\
\text { expectation }\end{array}$ & 0 & 1 & & & & \\
\hline & Travel attitudes - Frustrated traveller & 0 & 1 & & & & \\
\hline & Residential Attitudes - Social Context (ns) & 0 & 1 & & & & \\
\hline & $\begin{array}{l}\text { Residential Attitudes - Safety \& neatness } \\
\text { (ns) }\end{array}$ & 0 & 1 & & & & \\
\hline & Lifestyle - Low-budget and active/creative & 0 & 1 & & & & \\
\hline & Lifestyle - low-budget and active/creative & 0 & 1 & & & & \\
\hline & $\begin{array}{l}\text { Lifestyle - home-oriented traditional } \\
\text { family }\end{array}$ & 0 & 1 & & & & \\
\hline
\end{tabular}




\begin{tabular}{|c|c|c|c|c|c|c|c|}
\hline \multirow[b]{2}{*}{ Author(s) (year) } & \multirow[b]{2}{*}{ Cognitive Mechanism(s) } & \multicolumn{6}{|c|}{ Indicators of Study Quality } \\
\hline & & reliable & valid & $\begin{array}{l}\text { Large } \\
\text { sample } \\
\text { (Power } \\
\text { Analysis) }\end{array}$ & $\begin{array}{l}\text { Large } \\
\text { Sample } \\
\text { (SEM/Path } \\
=>200 \text { ) }\end{array}$ & $\begin{array}{l}\text { Repres } \\
\text { entativ } \\
\text { eness }\end{array}$ & $\begin{array}{l}\text { Total } \\
\text { Score }\end{array}$ \\
\hline & $\begin{array}{l}\text { Residential attitudes - Open space and } \\
\text { quietness }\end{array}$ & 0 & 1 & & & & \\
\hline & Travel attitudes - Pro-environment & 0 & 1 & & & & \\
\hline & $\begin{array}{l}\text { Lifestyle - Home-oriented but active } \\
\text { family }\end{array}$ & 0 & 1 & & & & \\
\hline & Residential attitude - Car alternatives & 0 & 1 & & & & \\
\hline & Travel mode attitudes - Car $=$ comfortable & 0 & 1 & & & & \\
\hline & $\begin{array}{l}\text { Travel mode attitudes }- \text { bike/on foot }= \\
\text { comfortable }\end{array}$ & 0 & 1 & & & & \\
\hline & $\begin{array}{l}\text { Travel mode attitudes - Car }=\text { negative } \\
\text { effects }\end{array}$ & 0 & 1 & & & & \\
\hline & Residential attitude - Accessibility & 0 & 1 & & & & \\
\hline & $\begin{array}{l}\text { Travel attitudes - Reduced driving social } \\
\text { expectation }\end{array}$ & 0 & 1 & & & & \\
\hline & Lifestyle - Friends \& trends & 0 & 1 & & & & \\
\hline & Travel mode attitudes $-\mathrm{PT}=$ comfortable & 0 & 1 & & & & \\
\hline & Travel mode attitudes $-\mathrm{PT}=$ time-saving & 0 & 1 & & & & \\
\hline & $\begin{array}{l}\text { Travel mode attitudes - PT = positive } \\
\text { effects }\end{array}$ & 0 & 1 & & & & \\
\hline & Travel Attitudes - Frustrated traveller & 0 & 1 & & & & \\
\hline & Residential Attitudes - Social Context (ns) & 0 & 1 & & & & \\
\hline & $\begin{array}{l}\text { Residential Attitudes - Safety \& neatness } \\
\text { (ns) }\end{array}$ & 0 & 1 & & & & \\
\hline & $\begin{array}{l}\text { Travel mode attitudes }- \text { bike/on foot }= \\
\text { positive effects }\end{array}$ & 0 & 1 & & & & \\
\hline & Lifestyle - Culture lover & 0 & 1 & & & & \\
\hline
\end{tabular}




\begin{tabular}{|c|c|c|c|c|c|c|c|}
\hline \multirow[b]{2}{*}{ Author(s) (year) } & \multirow[b]{2}{*}{ Cognitive Mechanism(s) } & \multicolumn{6}{|c|}{ Indicators of Study Quality } \\
\hline & & reliable & valid & $\begin{array}{l}\text { Large } \\
\text { sample } \\
\text { (Power } \\
\text { Analysis) } \\
\end{array}$ & $\begin{array}{l}\text { Large } \\
\text { Sample } \\
\text { (SEM/Path } \\
=>200)\end{array}$ & $\begin{array}{l}\text { Repres } \\
\text { entativ } \\
\text { eness }\end{array}$ & $\begin{array}{l}\text { Total } \\
\text { Score }\end{array}$ \\
\hline & $\begin{array}{l}\text { Residential attitudes - Open space and } \\
\text { quietness }\end{array}$ & 0 & 1 & & & & \\
\hline & Travel attitudes - Pro-environment & 0 & 1 & & & & \\
\hline & Residential attitude - Car alternatives & 0 & 1 & & & & \\
\hline & $\begin{array}{l}\text { Lifestyle - Home-oriented but active } \\
\text { family }\end{array}$ & 0 & 1 & & & & \\
\hline & $\begin{array}{l}\text { Travel mode attitudes }- \text { bike/on foot }= \\
\text { comfortable }\end{array}$ & 0 & 1 & & & & \\
\hline & $\begin{array}{l}\text { Travel mode attitudes - Car = negative } \\
\text { effects }\end{array}$ & 0 & 1 & & & & \\
\hline & Travel mode attitudes - Car $=$ comfortable & 0 & 1 & & & & \\
\hline & Lifestyle - Culture lover & 0 & 1 & & & & \\
\hline & Residential attitude - Accessibility & 0 & 1 & & & & \\
\hline & $\begin{array}{l}\text { Lifestyle - Home-oriented traditional } \\
\text { family }\end{array}$ & 0 & 1 & & & & \\
\hline & Travel mode attitudes $-\mathrm{PT}=$ comfortable & 0 & 1 & & & & \\
\hline & Travel mode attitudes $-\mathrm{PT}=$ time-saving & 0 & 1 & & & & \\
\hline & $\begin{array}{l}\text { Travel mode attitudes - PT = positive } \\
\text { effects }\end{array}$ & 0 & 1 & & & & \\
\hline & Lifestyle - Low-budget and active/creative & 0 & 1 & & & & \\
\hline & $\begin{array}{l}\text { Travel attitudes - Reduced driving social } \\
\text { expectation }\end{array}$ & 0 & 1 & & & & \\
\hline & Travel Attitudes - Frustrated traveller & 0 & 1 & & & & \\
\hline & Residential Attitudes - Social Context (ns) & 0 & 1 & & & & \\
\hline & $\begin{array}{l}\text { Residential Attitudes - Safety \& neatness } \\
\text { (ns) }\end{array}$ & 0 & 1 & & & & \\
\hline
\end{tabular}




\begin{tabular}{|c|c|c|c|c|c|c|c|}
\hline \multirow[b]{2}{*}{ Author(s) (year) } & \multirow[b]{2}{*}{ Cognitive Mechanism(s) } & \multicolumn{6}{|c|}{ Indicators of Study Quality } \\
\hline & & reliable & valid & $\begin{array}{l}\text { Large } \\
\text { sample } \\
\text { (Power } \\
\text { Analysis) }\end{array}$ & $\begin{array}{l}\text { Large } \\
\text { Sample } \\
\text { (SEM/Path } \\
=>200)\end{array}$ & $\begin{array}{l}\text { Repres } \\
\text { entativ } \\
\text { eness }\end{array}$ & $\begin{array}{l}\text { Total } \\
\text { Score }\end{array}$ \\
\hline & Lifestyle - Friends \& trends & 0 & 1 & & & & \\
\hline & $\begin{array}{l}\text { Travel mode attitudes }- \text { bike/on foot }= \\
\text { positive effects }\end{array}$ & 0 & 1 & & & & \\
\hline \multirow{8}{*}{ van Vugt et al. (1995) } & Prosocial Value Orientation & 0 & 1 & \multirow{8}{*}{$\mathrm{n} / \mathrm{a}$} & \multirow{8}{*}{0} & \multirow{8}{*}{0} & \multirow{8}{*}{0.1} \\
\hline & Importance environment & $\mathrm{n} / \mathrm{a}$ & 0 & & & & \\
\hline & Importance travel flexibility & $\mathrm{n} / \mathrm{a}$ & 0 & & & & \\
\hline & Importance public health & $\mathrm{n} / \mathrm{a}$ & 0 & & & & \\
\hline & Importance Cost & $\mathrm{n} / \mathrm{a}$ & 0 & & & & \\
\hline & Importance Convenience & $\mathrm{n} / \mathrm{a}$ & 0 & & & & \\
\hline & Importance Weather & $\mathrm{n} / \mathrm{a}$ & 0 & & & & \\
\hline & Importance travel time & $\mathrm{n} / \mathrm{a}$ & 0 & & & & \\
\hline \multirow{5}{*}{ van Vugt et al. (1996) } & $\begin{array}{l}\text { Collective motives (prosocial) - Concern } \\
\text { for environmental pollution }\end{array}$ & $\mathrm{n} / \mathrm{a}$ & 0 & \multirow{5}{*}{0} & \multirow{5}{*}{$\mathrm{n} / \mathrm{a}$} & \multirow{5}{*}{0} & \multirow{5}{*}{0.0} \\
\hline & $\begin{array}{l}\text { Individual motives (proself) - Travel } \\
\text { flexibility }\end{array}$ & $\mathrm{n} / \mathrm{a}$ & 0 & & & & \\
\hline & $\begin{array}{l}\text { Individual motives (proself) - Protection } \\
\text { against the weather }\end{array}$ & $\mathrm{n} / \mathrm{a}$ & 0 & & & & \\
\hline & $\begin{array}{l}\text { Individual motives (proself) - Travel } \\
\text { convenience }\end{array}$ & $\mathrm{n} / \mathrm{a}$ & 0 & & & & \\
\hline & Individual motives (proself) - Travel time & $\mathrm{n} / \mathrm{a}$ & 0 & & & & \\
\hline \multirow{4}{*}{$\begin{array}{l}\text { Verplanken et al. } \\
\text { (1994) }\end{array}$} & Attitudes - Car use & 0 & 0 & \multirow{4}{*}{$\mathrm{n} / \mathrm{a}$} & \multirow{4}{*}{0} & \multirow{4}{*}{0} & \multirow{4}{*}{0.3} \\
\hline & Habit - RFM & $\mathrm{n} / \mathrm{a}$ & 1 & & & & \\
\hline & Decisional involvement & 1 & 0 & & & & \\
\hline & Attitudes - Train use & 0 & 0 & & & & \\
\hline \multirow{3}{*}{$\begin{array}{l}\text { Verplanken et al. } \\
\text { (1998) }\end{array}$} & Habit - RFM & $\mathrm{n} / \mathrm{a}$ & 1 & \multirow{3}{*}{0} & \multirow{3}{*}{$\mathrm{n} / \mathrm{a}$} & \multirow{3}{*}{0} & \multirow{3}{*}{0.4} \\
\hline & Habit - SPB & $\mathrm{n} / \mathrm{a}$ & 1 & & & & \\
\hline & Intention - Car use & $\mathrm{n} / \mathrm{a}$ & 0 & & & & \\
\hline
\end{tabular}




\begin{tabular}{|c|c|c|c|c|c|c|c|}
\hline \multirow[b]{2}{*}{ Author(s) (year) } & \multirow[b]{2}{*}{ Cognitive Mechanism(s) } & \multicolumn{6}{|c|}{ Indicators of Study Quality } \\
\hline & & reliable & valid & $\begin{array}{l}\text { Large } \\
\text { sample } \\
\text { (Power } \\
\text { Analysis) } \\
\end{array}$ & $\begin{array}{l}\text { Large } \\
\text { Sample } \\
\text { (SEM/Path } \\
=>200 \text { ) }\end{array}$ & $\begin{array}{l}\text { Repres } \\
\text { entativ } \\
\text { eness }\end{array}$ & $\begin{array}{l}\text { Total } \\
\text { Score }\end{array}$ \\
\hline & PBC - Car use & $\mathrm{n} / \mathrm{a}$ & 0 & & & & \\
\hline & SN - Car use & $\mathrm{n} / \mathrm{a}$ & 0 & & & & \\
\hline & Attitudes - Car use & 1 & 0 & & & & \\
\hline $\begin{array}{l}\text { Verplanken et al. } \\
\text { (2008) }\end{array}$ & Environmental concern & 1 & 1 & 0 & $\mathrm{n} / \mathrm{a}$ & 0 & 1.0 \\
\hline \multirow{5}{*}{$\begin{array}{l}\text { Yang-Wallentin et al. } \\
(2004)\end{array}$} & Intention 1 - PT vs car & 0 & 0 & \multirow{5}{*}{$\mathrm{n} / \mathrm{a}$} & \multirow{5}{*}{1} & \multirow{5}{*}{0} & \multirow{5}{*}{1.0} \\
\hline & Intention 2 - PT vs car & 0 & 0 & & & & \\
\hline & Intention 3 - PT vs car & 0 & 0 & & & & \\
\hline & PBC 1 - PT vs car & 0 & 0 & & & & \\
\hline & PBC 2 - PT vs car & 0 & 0 & & & & \\
\hline
\end{tabular}

$\mathrm{n} / \mathrm{a}=$ not applicable, $\mathrm{PT}=$ public transport, $\mathrm{PBC}=$ perceived behavioural control, $\mathrm{RFM}=$ Response Frequency Measure, $\mathrm{SPB}=$ Self-reported frequency of past behaviour, $\mathrm{SN}=$ social norms, $\mathrm{PN}=$ personal norms, $\mathrm{GGE}=$ greenhouse gas emission 


\section{Cognitive Mechanisms of Travel Mode Choice}

The emerging groups were driven by the literature and often represent the structure of sociopsychological models, in particular the Theory of Planned Behaviour (TPB) (Ajzen, 1991). Sub-groups emerged where studies measured the same cognitive mechanism but with a conceptually distinctive content of that mechanism. Hence, cognitive mechanisms were often divided into car use and non-car-use. For example, studies measured the intention to use the car (car use Intentions) or the intention to use the car less (non-car-use Intentions). Other cognitive mechanisms, such as Identity, could not be considered conceptually distinct but correlations reported by three car-use studies (reporting 17 associations) could be considered congruent with car use (pro-car Identity) and incongruent with car use (anti-car Identity). Added specificity to modifiable determinants of socio-psychological models has been shown to add to their predictive validity (Kaiser \& Gutscher, 2003; Sheppard, Jon, \& Warshaw, 1988 ) and is now frequently adapted in transport research (e.g. Gardner \& Abraham, 2008, 2010; Mann \& Abraham, 2012).

Overall, 333 associations were identified in the literature. Figure S2 presents the number of cognitive mechanisms studies over time. Attitudes were the most widely researched cognitive mechanism. A plethora of associations characterised by inconsistent conceptualisations and operationalisations suggested a more fragmented approach to the synthesis of attitudinal variables. What studies denoted as "attitudes" varied from (1) general evaluations or beliefs about specific car use/ non-car-use attributes to, (2) concerns about or subjective importance of factors not related to car use/ non-car-use. Hence, we classified these into five different categories: (1) car use attitudes, (2) non-car-use attitudes, (3) attitudes towards travel in general, (4) attitudes towards the environment and health, and (5) attitudes towards transport environment.

Table S6 shows an overview of the emerged categories of cognitive mechanisms and the corresponding definition can be viewed in Table S7. For illustrative purposes, Table S6 includes the numbers for a meta-analysis where $k \geq 2$. 
Table S6. Overview of cognitive mechanisms studied and number of associations tested

\begin{tabular}{|c|c|c|c|c|c|}
\hline Cognitive mechanism & $\begin{array}{l}N \text { of } \\
\text { unique } \\
\text { studies }\end{array}$ & $\begin{array}{l}N \text { of unique } \\
\text { associations }\end{array}$ & $\begin{array}{l}\mathrm{N} \text { unique } \\
\text { studies in } \\
\text { MA car use } \\
\text { behaviour }\end{array}$ & $\begin{array}{c}\mathrm{N} \text { unique } \\
\text { studies in MA } \\
\text { non-car-use } \\
\text { behaviour }\end{array}$ & $\begin{array}{l}\text { Component } \\
\text { of which } \\
\text { model }\end{array}$ \\
\hline Attitude & 32 & 125 & 20 & 4 & \multirow{6}{*}{ ТРВ } \\
\hline Car use & 18 & 40 & 13 & 0 & \\
\hline Non-car-use & 10 & 25 & 3 & 4 & \\
\hline Travel in general & 5 & 17 & 3 & 0 & \\
\hline Environment \& health & 11 & 14 & 7 & 0 & \\
\hline Travel in general & 5 & 17 & 3 & 0 & \\
\hline Subjective norm (SN) & 19 & 23 & 8 & 5 & \multirow{3}{*}{ ТРB } \\
\hline Car use SN & 8 & 8 & 6 & 0 & \\
\hline Non-car-use SN & 12 & 15 & 3 & 5 & \\
\hline Descriptive norm & 4 & 4 & 3 & 0 & TPB \\
\hline Control Beliefs & 20 & 31 & 12 & 5 & \multirow{5}{*}{ ТPB } \\
\hline $\begin{array}{l}\text { Perceived Behavioural } \\
\text { Control (PBC) }\end{array}$ & 17 & 26 & 11 & 5 & \\
\hline Car use PBC & 8 & 13 & 6 & 0 & \\
\hline Non-car-use PBC & 11 & 13 & 5 & 5 & \\
\hline PBC - Environment & 5 & 5 & 4 & 0 & \\
\hline Intention & 17 & 21 & 10 & 5 & \multirow{3}{*}{ ТРB } \\
\hline Car use Intention & 9 & 9 & 7 & 0 & \\
\hline Non-car-use Intention & 8 & 12 & 3 & 5 & \\
\hline Personal Norm & 9 & 9 & 5 & 2 & NAM \\
\hline $\begin{array}{l}\text { Ascription of } \\
\text { Responsibility }\end{array}$ & 5 & 5 & 3 & $\mathbf{0}$ & NAM \\
\hline $\begin{array}{l}\text { Awareness of } \\
\text { Consequences }\end{array}$ & 8 & 11 & 5 & $\mathbf{0}$ & NAM \\
\hline $\begin{array}{l}\text { Altruistic Value } \\
\text { Orientation }\end{array}$ & 5 & 11 & 2 & $\mathbf{0}$ & VBN \\
\hline $\begin{array}{l}\text { Identity, Role Beliefs } \\
\text { \& Personality }\end{array}$ & 5 & 38 & 3 & $\mathbf{0}$ & \multirow{3}{*}{ TIB } \\
\hline Anti-car identity & 3 & 11 & 2 & 0 & \\
\hline Pro-car identity & 3 & 12 & 3 & 0 & \\
\hline Social Comparison & 3 & 6 & 2 & $\mathbf{n} / \mathbf{a}$ & $\mathrm{n} / \mathrm{a}$ \\
\hline Habit & 14 & 18 & 9 & 2 & \multirow{3}{*}{ TIB } \\
\hline RFM & 11 & 11 & 6 & 2 & \\
\hline Other measures & 5 & 7 & 5 & 0 & \\
\hline
\end{tabular}


Table S7. Definition of emerged categories of cognitive mechanisms

\begin{tabular}{|c|c|c|}
\hline $\begin{array}{l}\text { Cognitive } \\
\text { Mechanism } \\
\text { Category }\end{array}$ & Definition & Example Question \\
\hline $\begin{array}{l}\text { Car use } \\
\text { Attitude }\end{array}$ & $\begin{array}{l}\text { Relates to general evaluation of car use as } \\
\text { being good or bad, positive or negative, } \\
\text { favourable or unfavourable. Also contains } \\
\text { car-use-relevant beliefs (affective and } \\
\text { behavioural) }\end{array}$ & $\begin{array}{l}\text { "Making most of my journeys } \\
\text { next week by car would be" } \\
\text { good/bad } \\
\text { "The most cost-effective way of } \\
\text { getting to campus is by driving } \\
\text { there every day" } \\
\text { agree/disagree }\end{array}$ \\
\hline $\begin{array}{l}\text { Non-car-use } \\
\text { Attitude }\end{array}$ & $\begin{array}{l}\text { Relates to general evaluation of not using } \\
\text { the car or using any other transport mode } \\
\text { but the car as being good or bad, positive or } \\
\text { negative, favourable or unfavourable. Also } \\
\text { contains non-car-use-relevant beliefs } \\
\text { (affective and behavioural) }\end{array}$ & $\begin{array}{l}\text { "Making most of my journeys } \\
\text { next week without my car would } \\
\text { be" } \\
\text { good/bad }\end{array}$ \\
\hline $\begin{array}{l}\text { Attitude - } \\
\text { Travel in } \\
\text { General }\end{array}$ & $\begin{array}{l}\text { Evaluations, concerns or subjective } \\
\text { importance of travel characteristics not } \\
\text { specific to a particular mode. }\end{array}$ & $\begin{array}{l}\text { "To which extent are you } \\
\text { concerned with flexibility while } \\
\text { traveling" } \\
\text { very much/not at all }\end{array}$ \\
\hline $\begin{array}{l}\text { Attitude - } \\
\text { Environment \& } \\
\text { Health }\end{array}$ & $\begin{array}{l}\text { Comprises of general or specific } \\
\text { evaluations, subjective importance, worry, } \\
\text { opinions or concerns, about environment } \\
\text { and public health }\end{array}$ & $\begin{array}{l}\text { "I am worried about } \\
\text { environmental problems such as } \\
\text { air pollution, } \\
\text { noise, and energy use" } \\
\text { agree/disagree }\end{array}$ \\
\hline $\begin{array}{l}\text { Attitude - } \\
\text { Transport } \\
\text { Environment }\end{array}$ & $\begin{array}{l}\text { Combines evaluations, concerns or } \\
\text { subjective importance of spatial } \\
\text { characteristics, elements of urban design or } \\
\text { aspects of built-environment }\end{array}$ & $\begin{array}{l}\text { "How important are the } \\
\text { following features of the } \\
\text { neighbourhood for your personal } \\
\text { decision in favour of a certain } \\
\text { place of residence?" } \\
\text { agree/disagree }\end{array}$ \\
\hline $\begin{array}{l}\text { Car use } \\
\text { Subjective } \\
\text { Norm }\end{array}$ & $\begin{array}{l}\text { Are injunctive norms or normative beliefs } \\
\text { that refer to the individuals perception of } \\
\text { important others' beliefs about personal car } \\
\text { use }\end{array}$ & $\begin{array}{l}\text { "If I use a car for most of my } \\
\text { journeys in the next week, most } \\
\text { people who are important to me } \\
\text { would approve." } \\
\text { agree/disagree }\end{array}$ \\
\hline $\begin{array}{l}\text { Non-car-use } \\
\text { Subjective } \\
\text { Norm }\end{array}$ & $\begin{array}{l}\text { Are injunctive norms or normative beliefs } \\
\text { that refer to the individuals perception of } \\
\text { important others' beliefs about the } \\
\text { individual's non-car travel }\end{array}$ & $\begin{array}{l}\text { "People who are important to } \\
\text { me expect that I will use } \\
\text { environmentally friendly means } \\
\text { of transportation." } \\
\text { agree/disagree }\end{array}$ \\
\hline $\begin{array}{l}\text { Descriptive } \\
\text { Norm }\end{array}$ & $\begin{array}{l}\text { Is the individual perception of other } \\
\text { people's car-use-relevant behaviour }\end{array}$ & $\begin{array}{l}\text { "Most people who are important } \\
\text { to me use a car for most of their } \\
\text { journeys within the city" } \\
\text { agree/disagree }\end{array}$ \\
\hline $\begin{array}{l}\text { Car use } \\
\text { Intention }\end{array}$ & $\begin{array}{l}\text { Refers to the intention to choose the car for } \\
\text { journeys (over a certain period of time or at } \\
\text { a specific time point) }\end{array}$ & $\begin{array}{l}\text { "I intend to use the car for most } \\
\text { of my journeys during the next } \\
\text { week" } \\
\text { agree/disagree }\end{array}$ \\
\hline $\begin{array}{l}\text { Non-car-use } \\
\text { Intention }\end{array}$ & $\begin{array}{l}\text { Is the intention to reduce car use or to use } \\
\text { any other form of transport than/instead of } \\
\text { the car }\end{array}$ & $\begin{array}{l}\text { "I intend to use PT instead of the } \\
\text { car for daily trips from my } \\
\text { residence" } \\
\text { agree/disagree }\end{array}$ \\
\hline
\end{tabular}




\begin{tabular}{|c|c|c|}
\hline $\begin{array}{l}\text { Cognitive } \\
\text { Mechanism } \\
\text { Category }\end{array}$ & Definition & Example Question \\
\hline Car use PBC & $\begin{array}{l}\text { Refers to beliefs about the capability of } \\
\text { using the car }\end{array}$ & $\begin{array}{l}\text { "Circumstances force me to use } \\
\text { the car on my frequent trips" } \\
\text { agree/disagree }\end{array}$ \\
\hline $\begin{array}{l}\text { Non-car-use } \\
\text { PBC }\end{array}$ & $\begin{array}{l}\text { Are beliefs about the capability of using } \\
\text { any other mode of transport than/instead of } \\
\text { the car }\end{array}$ & $\begin{array}{l}\text { "For me to use PT instead of the } \\
\text { car for daily trips from my } \\
\text { residence would be" } \\
\text { easy/difficult }\end{array}$ \\
\hline $\begin{array}{l}\text { PBC - } \\
\text { Environment }\end{array}$ & $\begin{array}{l}\text { Relate to beliefs about the capability of } \\
\text { reducing environmental problems by } \\
\text { decisions regarding transport. Can also } \\
\text { relate to personal belief/opinion about } \\
\text { activities that are essential in ameliorating } \\
\text { the environmental state. }\end{array}$ & $\begin{array}{l}\text { "Through my transport } \\
\text { decisions, I can make a } \\
\text { difference to the environment" } \\
\text { agree/disagree }\end{array}$ \\
\hline $\begin{array}{l}\text { Non-car-use } \\
\text { Personal Norm }\end{array}$ & $\begin{array}{l}\text { Relates to the moral obligation or the } \\
\text { individual's values to use non-car travel } \\
\text { modes }\end{array}$ & $\begin{array}{l}\text { "Due to values important to me, } \\
\text { I feel obliged to use the car } \\
\text { as little as possible." } \\
\text { agree/disagree }\end{array}$ \\
\hline $\begin{array}{l}\text { Awareness of } \\
\text { Consequences }\end{array}$ & $\begin{array}{l}\text { Describes certain degree of awareness/ } \\
\text { concern with consequences that individual's } \\
\text { own actions or other people's actions with } \\
\text { regards to car use are harmful/have bad } \\
\text { consequences for the environment and } \\
\text { society }\end{array}$ & $\begin{array}{l}\text { "Car use causes serious air } \\
\text { pollution in the world" } \\
\text { agree/disagree }\end{array}$ \\
\hline $\begin{array}{l}\text { Ascription of } \\
\text { Responsibilities }\end{array}$ & $\begin{array}{l}\text { Refers to the extent to which the individual } \\
\text { feels responsible that his/her own car-use- } \\
\text { related actions or other people's car-use- } \\
\text { related actions can influence these } \\
\text { consequences/(environment and societal) } \\
\text { problems }\end{array}$ & $\begin{array}{l}\text { "I feel personally obliged to } \\
\text { reduce smog" } \\
\text { agree/disagree }\end{array}$ \\
\hline $\begin{array}{l}\text { Altruistic } \\
\text { Value } \\
\text { Orientation }\end{array}$ & $\begin{array}{l}\text { Items were categorised when studies } \\
\text { explicitly referred to the construct as being } \\
\text { a value orientation }\end{array}$ & $\begin{array}{l}\text { "How important is [value] to } \\
\text { you as a guiding principle of } \\
\text { life?" } \\
\text { very important/not at all }\end{array}$ \\
\hline $\begin{array}{l}\text { Identity, Role } \\
\text { Beliefs \& } \\
\text { Personality }\end{array}$ & $\begin{array}{l}\text { Refers to several measures/ways in } \\
\text { measuring of an individual's set of } \\
\text { characteristics/lifestyle desires/personality } \\
\text { or general efforts to establish a person's } \\
\text { individuality }\end{array}$ & $\begin{array}{l}\text { "How important to you is } \\
\text { [identity] in defining who you } \\
\text { are?" } \\
\text { very important/not at all }\end{array}$ \\
\hline $\begin{array}{l}\text { Social } \\
\text { Comparison }\end{array}$ & $\begin{array}{l}\text { Refers to items asking in how far people } \\
\text { compare their own actions with others' and } \\
\text { also in how far they try to exceed others }\end{array}$ & $\begin{array}{l}\text { "I can distinguish myself from } \\
\text { others" } \\
\text { agree/disagree }\end{array}$ \\
\hline $\begin{array}{l}\text { Car use Habit - } \\
\text { RFM }\end{array}$ & $\begin{array}{l}\text { Car use habit measured using the Response } \\
\text { Frequency Measure (RFM) by Verplanken } \\
\text { et al. (1994) }\end{array}$ & $\mathrm{n} / \mathrm{a}$ \\
\hline $\begin{array}{l}\text { Car use Habit - } \\
\text { Other } \\
\text { Measures }\end{array}$ & Car use habit measured not using the RFM & $\mathrm{n} / \mathrm{a}$ \\
\hline
\end{tabular}


2

3

4

5

6

7

8

9

10

11

12

13

14

15

16

17

18

19

20

21

22

23

24

25

26

27

28

29

30

31

32

33

34

35

36

37

38

39

40

41

42

43

44

45

46

47

48

49

50

51

52

53

54

55

56

57

58

59

60

Figure S1. Number of cognitive mechanisms measured over time



URL: http://mc.manuscriptcentral.com/ttrv 


\section{Further Details on Meta-analysis}

Correlation coefficients could be extracted from 26 retrieved papers. In addition, 19 authors were asked to provide missing data and nine were willing/able to do so. We excluded Nilsson and Küller's (2000) study because it was not possible to determine if the dependent variable measured car use or non-car-use and because four out of six scales measure cognitive mechanisms showed low internal reliability e.g., Attitude - public transport ( $\alpha=.48$ ), Attitude - personal concern $(\alpha=.35)$, Attitude - environmental concern $(\alpha=.50)$, Environmental Knowledge $(\alpha=.44)$. One study reported cognitive mechanisms for both, car use and non-caruse (Scheiner \& Holz-Rau, 2007) and was therefore included in both meta-analyses. The following chapters complement the results section and further describes salient observations made during the synthesised literature as well as more detailed results tables.

\subsection{Car Use Intentions towards Car Use}

The high heterogeneity index could be due to considerably different individual effect sizes. Two of the non-urban studies (Panter, Desousa, \& Ogilvie, 2013; Verplanken, Aarts, van Knippenberg, \& Moonen, 1998) reported effect sizes of $r=.11$ and $r=.20$, respectively, whereas Mann and Abraham (2006) reported a very large relationship between intentions and car use $(r=.88)$. This can be explained by the study being conducted at a location (Falmer Campus, Sussex University) that is very accessible via multiple modes of transport and is being served by regular public transport. Therefore, although being in a rural location, the geographical conditions are not representative for rural locations, traditionally considered remote.

\subsection{Awareness of Consequences towards Car Use}

Studies used different measures to assess the awareness of consequences. Some items referred to impacts on the environment or society due to actions of the individual (Steg \& Sievers, 2000) and some to the behaviour in general (Tanner, 1999). This might be due different conceptualisations of this cognitive mechanism that exist in the literature. Steg (2005), for instance, explains that a "person needs to be aware of consequences of their own behaviour for others or the environment" (Awareness of Consequences) and that he "needs to feel personally responsible for these problems" (Ascription of Responsibilities). Stern et al. (1999) define Awareness of Consequences as "awareness of threats to nonhuman species and the biosphere" and Ascription of Responsibilities as "the belief that action can alleviate 
consequences". Lastly, Schwartz adopted the general approach and conceptualised Awareness of Consequences as "the extent to which someone is aware of adverse consequences of not acting prosocial for others or for other things one values" and Ascription of Responsibilities as a construct that "reflects feelings of responsibility for negative consequences of not acting prosocial"

\subsection{Car Use Habit - Other Measure towards Car Use}

Friedrichsmeier, Matthies, and Klöckner (2013) included four different operationalisations of habit and tested associations of script-based, past behaviour, self-report habit index and context stability separately. Therefore, this study was included in the category of RFM of car use habit and also in the category for other habit measures. Likewise, Verplanken et al. (1998) applied two different measures for habit (RFM and past behaviour) and provided two separate correlation coefficients for the two measures hence are included in both groups. Klöckner and Blöbaum (2010) used two different measures of habit (RFM and self-report habit index) but combined the two scales into one variable on the grounds of acceptable inter-correlation $(\alpha$ $=.73$ ). This study was therefore included in the category "other habit measures".

\subsection{Longitudinal Studies}

We identified four longitudinal studies in the review of which three were eligible to be entered into meta-analyses (Armitage et al., 2013; Friedrichsmeier et al., 2013; Tischer \& Phillips, 1979). Across three studies, ten associations with car use were tested, all corresponding to a different cognitive mechanism category (see table below). In all cases, individual effect sizes were the expected direction and in many cases the magnitude was consistent with the pooled effect size for the cognitive mechanism. Unfortunately, we were unable to conduct a separate meta-analysis for those studies as insufficient number of studies reported correlation coefficients for the same cognitive mechanism.

Table S8: Effect sizes of longitudinal studies

\begin{tabular}{|l|l|r|r|}
\hline \multicolumn{1}{|c|}{ Study } & Cognitive Mechanism Category & study effect size $r$ & \multicolumn{1}{c|}{$r+$} \\
\hline Tischer \& Phillips (1979) & Car Use Attitudes & 0.29 & 0.36 \\
\hline Friedrichsmeier et al. (2013) & Car Use Habit - RFM & 0.44 & 0.47 \\
& Car Use Intentions & 0.51 & 0.5 \\
\hline Armitage et al. (2013) & Non-car-use PBC & -0.261 & -0.47 \\
& Non-car-use Attitudes & -0.098 & -0.23 \\
& Non-car-use Subjective Norms & -0.072 & -0.15 \\
& Non-car-use Intentions & -0.127 & 0.38 \\
\hline
\end{tabular}


Table S9. Detailed results of the meta-analysis of car use

\begin{tabular}{|c|c|c|c|c|c|c|c|c|}
\hline Cognitive mechanism (sub-groups) & $n$ & $k$ & $K$ & $r+$ & $95 \% \mathrm{CI}$ & $\left.I^{2} \%\right)$ & $X^{2}$ & Egger's test \\
\hline Car Use Attitudes & 4647 & 38 & 12 & $0.22 * * *$ & $0.13,0.30$ & 91.6 & $115.52 * * *$ & $6.8(p=0.01)$ \\
\hline non-urban & 3186 & 29 & 6 & $0.14^{* * *}$ & $0.06,0.23$ & 87.2 & $28.54 * * *$ & $8.8(p=0.07)$ \\
\hline urban & 1461 & 9 & 6 & $0.31 * * *$ & $0.21,0.41$ & 83.2 & $28.66 * * *$ & $3.6(p=0.17)$ \\
\hline non-commuting journeys & 3019 & 24 & 6 & $0.15^{* *}$ & $0.05,0.25$ & 92.4 & $52.85 * * *$ & $9.4(p=0.12)$ \\
\hline commuting journeys & 1628 & 14 & 6 & $0.34 * * *$ & $0.26,0.42$ & 78 & $21.33 * * *$ & $4.2(p=0.11)$ \\
\hline non-European & 927 & 3 & 3 & $0.37 * * *$ & $0.26,0.48$ & 83.9 & $11.55 * *$ & $7.8(p=0.10)$ \\
\hline European & 3720 & 35 & 9 & $0.18 * * *$ & $0.09,0.27$ & 90.8 & $73.57 * * *$ & $6.3(p=0.04)$ \\
\hline typical car use & 4218 & 28 & 10 & $0.21^{* * *}$ & $0.12,0.30$ & 92.3 & $101.16^{* * *}$ & $6.5(p=0.01)$ \\
\hline actual car use & 429 & 10 & 2 & $0.28^{*}$ & $0.06,0.50$ & 92 & $12.47 * * *$ & - \\
\hline TPB measures & 1290 & 6 & 6 & $0.33^{* * *}$ & $0.20,0.46$ & 89.3 & $42.97 * * *$ & $2.8(p=0.62)$ \\
\hline Beliefs & 3586 & 32 & 7 & $0.19 * * *$ & $0.09,0.29$ & 92.2 & $69.25 * * *$ & $9.2(p=0.01)$ \\
\hline Non-car-use Attitudes & 812 & 3 & 3 & $-0.23 * *$ & $-0.40,-0.06$ & 90.7 & $20.14 * * *$ & - \\
\hline Attitudes - Travel in General & 1486 & 10 & 3 & 0.05 & $-0.05,0.15$ & 84.6 & $11.92 * *$ & - \\
\hline Attitudes - Environment \& Health & 4097 & 9 & 7 & $-0.10 * *$ & $-0.17,-0.03$ & 86.2 & $40.68 * * *$ & - \\
\hline non-urban & 2804 & 3 & 3 & -0.09 & $-0.18,0.00$ & 89 & $18.31 * * *$ & - \\
\hline urban & 1293 & 6 & 4 & $-0.13 *$ & $-0.25,0.00$ & 87.4 & $21.31 * * *$ & - \\
\hline Attitudes - Transport Environment & 4811 & 12 & 4 & $-0.28 * * *$ & $-0.41,-0.15$ & 97.5 & $104.16 * * *$ & - \\
\hline non-urban & 1759 & 8 & 2 & $-0.17 * * *$ & $-0.23,-0.11$ & 70.5 & 3.34 & - \\
\hline urban & 3052 & 4 & 2 & $-0.35 * * *$ & $-0.52,-0.17$ & 98.6 & $64.26 * * *$ & - \\
\hline Car Use Subjective Norms & 1455 & 6 & 6 & $0.20 * *$ & $0.05,0.35$ & 91.3 & $53.18 * * *$ & $12.2(p=0.20)$ \\
\hline Non-car-use Subjective Norms & 944 & 3 & 3 & $-0.15 * * *$ & $-0.20,-0.11$ & $\mathbf{0}$ & 1.31 & - \\
\hline Car Use Descriptive Norms & 532 & 3 & 3 & -0.07 & $-0.35,0.21$ & 94.2 & $32.44 * * *$ & - \\
\hline Car Use PBC & 1605 & 9 & 5 & $0.39 * * *$ & $0.18,0.6$ & 97.1 & $110.83 * * *$ & $-6.3(p=0.75)$ \\
\hline Non-car-use PBC & 1200 & 5 & 5 & $-0.42 * * *$ & $-0.57,-0.28$ & 93 & $49.24 * * *$ & - \\
\hline PBC - Environment & 324 & 4 & 4 & $-0.08 * *$ & $-0.17,-0.05$ & 52.8 & 6.3 & - \\
\hline
\end{tabular}




\begin{tabular}{|c|c|c|c|c|c|c|c|c|}
\hline Car Use Intentions & 2375 & 7 & 7 & $0.50 * * *$ & $0.31,0.68$ & 98.3 & $262.35 * * *$ & $8.3(p=0.33)$ \\
\hline non-urban & 844 & 3 & 3 & 0.34 & $-0.04,0.71$ & 99.2 & $118.42 * * *$ & - \\
\hline urban & 1531 & 4 & 4 & $0.59 * * *$ & $0.47,0.70$ & 95.6 & $49.6^{* * *}$ & $9.1(p=0.01)$ \\
\hline non-commuting journeys & 1438 & 3 & 3 & $0.50 * * *$ & $0.33,0.67$ & 96.7 & $54.89 * * *$ & - \\
\hline commuting journeys & 937 & 4 & 4 & $0.50 * *$ & $0.15,0.85$ & 98.9 & $207.12 * * *$ & $26.4(p=0.24)$ \\
\hline typical car use & 1839 & 4 & 4 & $0.47 * * *$ & $0.26,0.67$ & 97.9 & $135.45 * * *$ & $6.2(p=0.62)$ \\
\hline actual car use & 536 & 3 & 3 & $0.62 * * *$ & $0.25,0.98$ & 98.7 & $143.41 * * *$ & - \\
\hline Non-car-use Intentions & 943 & 3 & 3 & $-0.38 *$ & $-0.68,-0.09$ & 98.1 & $87.86 * * *$ & - \\
\hline Non-car-use Personal Norms & 793 & 5 & 5 & $-0.35 * * *$ & $-0.42,-0.28$ & 69.3 & $12.32 *$ & - \\
\hline Ascription of Responsibilities & 642 & 3 & 3 & -0.14 & $-0.31,0.03$ & 87.7 & $14.69 * * *$ & - \\
\hline Awareness of Consequences & 2139 & 6 & 5 & $-0.22 * * *$ & $-0.29,-0.16$ & 69.1 & $12.72 *$ & - \\
\hline Altruistic Value Orientation & 184 & 3 & 2 & $-0.32 * * *$ & $-0.34,-0.29$ & $\mathbf{0}$ & $\mathbf{0 . 0 7}$ & - \\
\hline Identity Anti-Car & 1609 & 11 & 2 & $-0.08 * *$ & $-0.11,-0.02$ & 39.1 & 1.64 & - \\
\hline Identity Pro-Car & 4229 & 11 & 3 & $0.05^{* * * *}$ & $0.04,0.07$ & $\mathbf{0}$ & $\mathbf{0 . 8 8}$ & - \\
\hline Social Comparison & 1247 & 6 & 2 & $0.16 * *$ & $0.06,0.26$ & 84.5 & $6.61 *$ & - \\
\hline Car Use Habit - RFM & 2058 & 6 & 6 & $0.47^{* * * *}$ & $0.39,0.56$ & 89 & $37.70 * * *$ & $2.7(p=0.42)$ \\
\hline typical car use & 445 & 3 & 3 & $0.53 * * *$ & $0.39,0.66$ & 87.9 & $11.55^{* *}$ & - \\
\hline actual car use & 1613 & 3 & 3 & $0.46^{* * *}$ & $0.35,0.57$ & 92.1 & $24.19 * * *$ & - \\
\hline Car Use Habit - Other Measures & 2160 & 7 & 5 & $0.38 * * *$ & $0.20,0.56$ & 97.8 & $128.33 * * *$ & $7(p=0.48)$ \\
\hline past behaviour & 1248 & 2 & 2 & $0.58^{* * *}$ & $0.37,0.78$ & 97.7 & $60.06^{* * *}$ & - \\
\hline SRHI & 523 & 2 & 2 & 0.28 & $-0.08,0.64$ & 98.6 & $40.97 * * *$ & - \\
\hline latent variable & 1437 & 2 & 2 & $0.49^{* * *}$ & $0.29,0.69$ & 98.6 & $52.62 * * *$ & - \\
\hline
\end{tabular}


Table S10. Detailed results of the meta-analysis of non-car-use

\begin{tabular}{|c|c|c|c|c|c|c|c|c|}
\hline Cognitive mechanism (sub-groups) & $n$ & $k$ & $K$ & $r+$ & $95 \% \mathrm{CI}$ & $I^{2}(\%)$ & $X^{2}$ & Egger's test \\
\hline Non-car-use Attitudes & 2597 & 7 & 4 & $0.36 * * *$ & $0.21,0.51$ & 97.1 & $79.26 * * *$ & $11.3(p=0.19)$ \\
\hline Non-car-use Subjective Norms & 2745 & 6 & 5 & $0.28 * * *$ & $0.14,0.41$ & 95.6 & $78.47 * * *$ & $5.1(p=0.41)$ \\
\hline Non-car-use PBC & 3500 & 9 & 5 & $0.49 * * *$ & $0.41,0.57$ & 93.9 & $55.08 * * *$ & $8.3(p=0.14)$ \\
\hline typical non-car-use & 2347 & 4 & 3 & $0.49^{* * *}$ & $0.39,0.59$ & 93.3 & $26.02 * * *$ & - \\
\hline actual non-car-use & 1153 & 3 & 2 & $0.50 * * *$ & $0.34,0.66$ & 97.2 & $29.11 * * *$ & - \\
\hline Non-car-use Intentions & 3493 & 8 & 5 & $0.48 * * *$ & $0.35,0.61$ & 97.3 & $131.63 * * *$ & $11.8(p=0.18)$ \\
\hline$* p<.05, * * p<.01, * * * p<.001$ & & & & & & & & \\
\hline
\end{tabular}




\section{References}

Ahlport, K. N., Linnan, L., Vaughn, A., Evenson, K. R., \& Ward, D. S. (2008). Barriers to and facilitators of walking and bicycling to school: formative results from the nonmotorized travel study. Health Educ Behav, 35(2), 221-244. doi:

$10.1177 / 1090198106288794$

Ajzen, I. (1991). The theory of planned behavior. Organizational behavior and human decision processes, 50(2), 179-211.

Baslington, H. (2008). Travel socialization: A social theory of travel mode behavior. International journal of sustainable transportation, 2(2), 91-114

Cooper, A. R., Page, A. S., Wheeler, B. W., Griew, P., Davis, L., Hillsdon, M., \& Jago, R. (2010). Mapping the Walk to School Using Accelerometry Combined with a Global Positioning System. American Journal of Preventive Medicine, 38(2), 178-183. doi: http://dx.doi.org/10.1016/j.amepre.2009.10.036

DiGuiseppi, C., Roberts, I., Li, L., \& Allen, D. (1998). Determinants of car travel on daily journeys to school: cross sectional survey of primary school children. $B M J$, 316(7142), 1426-1428. doi: 10.1136/bmj.316.7142.1426

Friedrichsmeier, T., Matthies, E., \& Klöckner, C. A. (2013). Explaining stability in travel mode choice: An empirical comparison of two concepts of habit. Transportation Research Part F: Traffic Psychology and Behaviour, 16, pp 1-13

Haustein, S., \& Hunecke, M. (2007). Reduced use of environmentally friendly modes of transportation caused by perceived mobility necessities: An extension of the theory of planned behavior. Journal of Applied Social Psychology, 37(8), 1856-1883. doi: 10.1111/j.1559-1816.2007.00241.x

Joireman, J. A., Van Lange, P. A. M., Kuhlman, D. M., Van Vugt, M., \& Shelley, G. P. (1997). An interdependence analysis of commuting decisions. European Journal of Social Psychology, 27(4), 441-463. doi: 10.1002/(SICI)10990992(199707)27:4<441::AID-EJSP804>3.0.CO;2-S

Klöckner, C. A., \& Blöbaum, A. (2010). A comprehensive action determination model. Toward a broader understanding of ecological behaviour using the example of travel mode choice. Journal of Environmental Psychology, 30(4), 574-586. doi: 10.1016/j.jenvp.2010.03.001 
Mann, E., \& Abraham, C. (2006). The role of affect in UK commuters' travel mode choices: An interpretative phenomenological analysis. British Journal of Psychology, 97, 155176. doi: $10.1348 / 000712605 \times 61723$

McDonald, N. C. (2008). Household interactions and children's school travel: the effect of parental work patterns on walking and biking to school. Journal of Transport Geography, 16(5), 324-331. doi: 10.1016/j.jtrangeo.2008.01.002

Murtagh, N., Gatersleben, B., \& Uzzell, D. (2012). Multiple identities and travel mode choice for regular journeys. Transportation Research Part F: Traffic Psychology and Behaviour, 15(5), pp 514-524

Nilsson, M., \& Kuller, R. (2000). Travel behaviour and environmental concern. Transportation Research Part D-Transport and Environment, 5(3), 211-234. doi: 10.1016/s1361-9209(99)00034-6

Panter, J., Desousa, C., \& Ogilvie, D. (2013). Incorporating walking or cycling into car journeys to and from work: The role of individual, workplace and environmental characteristics. Preventive Medicine, 56(3-4), 211-217. doi: 10.1016/j.ypmed.2013.01.014

Scheiner, J., \& Holz-Rau, C. (2007). Travel mode choice: affected by objective or subjective determinants? Transportation, 34(4), 487-511

Steg, L., \& Sievers, I. (2000). Cultural theory and individual perceptions of environmental risks. Environment and Behavior, 32(2), 250-269

Tanner, C. (1999). Constraints on environmental behaviour. Journal of Environmental Psychology, 19(2), 145-157. doi: http://dx.doi.org/10.1006/jevp.1999.0121

Tischer, M. L., \& Phillips, R. V. (1979). Relationship between transportation perceptions and behavior over time. Transportation (Netherlands), 8(1), p. 21-36

van Vugt, M., van Lange, P. A. M., \& Meertens, R. M. (1996). Commuting by car or public transportation? A social dilemma analysis of travel mode judgements. European Journal of Social Psychology, 26(3), 373-395

Verplanken, B., Aarts, H., van Knippenberg, A., \& Moonen, A. (1998). Habit versus planned behaviour: A field experiment. The British Journal of Social Psychology, 37, 111-128

Yarlagadda, A. K., \& Srinivasan, S. (2007). Modeling children's school travel mode and parental escort decisions. Transportation, 35(2), 201-218. doi: 10.1007/s11116-0079144-6 
Figure 1. Preferred Reporting Items for Systematic Review and Meta-Analyses (PRISMA) flowchart Figure 1 near here 


\begin{tabular}{|c|c|c|c|c|c|c|}
\hline Cognitive mechanism (sub-groups) & $n$ & $k$ & $r+$ & $95 \% \mathrm{CI}$ & $I^{2}(\%)$ & Egger's test \\
\hline Car Use Attitudes & 4647 & 38 & $0.22 * * *$ & $0.13,0.30$ & 91.6 & $6.8(p=0.01)$ \\
\hline non-urban & 3186 & 29 & $0.14 * * *$ & $0.06,0.23$ & 87.2 & $8.8(p=0.07)$ \\
\hline urban & 1461 & 9 & $0.31 * * *$ & $0.21,0.41$ & 83.2 & $3.6(p=0.17)$ \\
\hline non-commuting journeys & 3019 & 24 & $0.15^{* *}$ & $0.05,0.25$ & 92.4 & $9.4(p=0.12)$ \\
\hline commuting journeys & 1628 & 14 & $0.34 * * *$ & $0.26,0.42$ & 78 & $4.2(p=0.11)$ \\
\hline non-European & 927 & 3 & $0.37 * * *$ & $0.26,0.48$ & 83.9 & $7.8(p=0.10)$ \\
\hline European & 3720 & 35 & $0.18^{* * *}$ & $0.09,0.27$ & 90.8 & $6.3(p=0.04)$ \\
\hline typical car use & 4218 & 28 & $0.21 * * *$ & $0.12,0.30$ & 92.3 & $6.5(p=0.01)$ \\
\hline actual car use & 429 & 10 & $0.28 *$ & $0.06,0.50$ & 92 & - \\
\hline TPB measures & 1290 & 6 & $0.33^{* * *}$ & $0.20,0.46$ & 89.3 & $2.8(p=0.62)$ \\
\hline Beliefs & 3586 & 32 & $0.19 * * *$ & $0.09,0.29$ & 92.2 & $9.2(p=0.01)$ \\
\hline Non-car-use Attitudes & 812 & 3 & $-0.23 * *$ & $-0.40,-0.06$ & 90.7 & - \\
\hline Attitudes - Travel in General & 1486 & 10 & 0.05 & $-0.05,0.15$ & 84.6 & - \\
\hline Attitudes - Environment \& Health & 4097 & 9 & $-0.10 \div *$ & $-0.17,-0.03$ & 86.2 & - \\
\hline non-urban & 2804 & 3 & -0.09 & $-0.18,0.00$ & 89 & - \\
\hline urban & 1293 & 6 & $-0.13 *$ & $-0.25,0.00$ & 87.4 & - \\
\hline Attitudes - Transport Environment & 4811 & 12 & $-0.28 * * *$ & $-0.41,-0.15$ & 97.5 & - \\
\hline non-urban & 1759 & 8 & $-0.17 * * *$ & $-0.23,-0.11$ & 70.5 & - \\
\hline urban & 3052 & 4 & $-0.35 * * *$ & $-0.52,-0.17$ & 98.6 & - \\
\hline Car Use Subjective Norms & 1455 & 6 & $0.20 * *$ & $0.05,0.35$ & 91.3 & $12.2(p=0.20)$ \\
\hline Non-car-use Subjective Norms & 944 & 3 & $-0.15 * * *$ & $-0.20,-0.11$ & $\mathbf{0}$ & - \\
\hline Car Use Descriptive Norms & 532 & 3 & -0.07 & $-0.35,0.21$ & 94.2 & - \\
\hline Car Use PBC & 1605 & 9 & $0.39 * * *$ & $0.18,0.60$ & 97.1 & $-6.3(p=0.75)$ \\
\hline Non-car-use PBC & 1200 & 5 & $-0.42 * * *$ & $-0.57,-0.28$ & 93 & - \\
\hline PBC - Environment & 324 & 4 & $-0.08 * *$ & $-0.17,-0.05$ & 52.8 & - \\
\hline Car Use Intentions & 2375 & 7 & $0.50 * * *$ & $0.31,0.68$ & 98.3 & $8.3(p=0.33)$ \\
\hline non-urban & 844 & 3 & 0.34 & $-0.04,0.71$ & 99.2 & - \\
\hline urban & 1531 & 4 & $0.59 * * *$ & $0.47,0.70$ & 95.6 & $9.1(p=0.01)$ \\
\hline non-commuting journeys & 1438 & 3 & $0.50 * * *$ & $0.33,0.67$ & 96.7 & - \\
\hline commuting journeys & 937 & 4 & $0.50 * *$ & 0.85 & 98.9 & $26.4(p=0.24)$ \\
\hline typical car use & 1839 & 4 & $0.47 * * *$ & $0.26,0.67$ & 97.9 & $6.2(p=0.62)$ \\
\hline actual car use & 536 & 3 & $0.62 * * *$ & $0.25,0.98$ & 98.7 & - \\
\hline Non-car-use Intentions & 943 & 3 & $-0.38 *$ & $-0.68,-0.09$ & 98.1 & - \\
\hline Non-car-use Personal Norms & 793 & 5 & $-0.35 * * *$ & $-0.42,-0.28$ & 69.3 & - \\
\hline Ascription of Responsibilities & 642 & 3 & -0.14 & $-0.31,0.03$ & 87.7 & - \\
\hline Awareness of Consequences & 2139 & 6 & $-0.22 * * *$ & $-0.29,-0.16$ & 69.1 & - \\
\hline Altruistic Value Orientation & 184 & 3 & $-0.32 * * *$ & $-0.34,-0.29$ & $\mathbf{0}$ & - \\
\hline Identity Anti-Car & 1609 & 11 & $-0.08 * *$ & $-0.11,-0.02$ & 39.1 & - \\
\hline Identity Pro-Car & 4229 & 11 & $0.05 * * *$ & $0.04,0.07$ & $\mathbf{0}$ & - \\
\hline Social Comparison & 1247 & 6 & $0.16 * *$ & $0.06,0.26$ & 84.5 & - \\
\hline Car Use Habit - RFM & 2058 & 6 & $0.47 * * *$ & $0.39,0.56$ & 89 & $2.7(p=0.42)$ \\
\hline typical car use & 445 & 3 & $0.53 * * *$ & $0.39,0.66$ & 87.9 & - \\
\hline actual car use & 1613 & 3 & $0.46^{* * *}$ & $0.35,0.57$ & 92.1 & - \\
\hline Car Use Habit - & 2160 & 7 & $0.38 * * *$ & $0.20,0.56$ & 97.8 & $7(p=0.48)$ \\
\hline
\end{tabular}




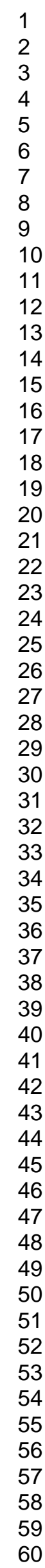

\begin{tabular}{|lrlllll|} 
past behaviour & 1248 & 2 & $0.58 * * *$ & $0.37,0.78$ & 97.7 & - \\
SRHI & 523 & 2 & 0.28 & $-0.08,0.64$ & 98.6 & - \\
latent variable & 1437 & 2 & $0.49 * * *$ & $0.29,0.69$ & 98.6 & - \\
\hline$* p<.05, * * p<.01, * * * p<.001$ & & & & &
\end{tabular}

Table 1. Results of the meta-analysis of car use 


\begin{tabular}{|c|c|c|c|c|c|c|}
\hline Cognitive mechanism (sub-groups) & $n$ & $k$ & $r+$ & $95 \% \mathrm{CI}$ & $I^{2}(\%)$ & Egger's test \\
\hline Non-car-use Attitudes & 2597 & 7 & $0.36 * * *$ & $0.21,0.51$ & 97.1 & $11.3(p=0.19)$ \\
\hline Non-car-use Subjective Norms & 2745 & 6 & $0.28 * * *$ & $0.14,0.41$ & 95.6 & $5.1(p=0.41)$ \\
\hline Non-car-use PBC & 3500 & 9 & $0.49 * * *$ & $0.41,0.57$ & 93.9 & $8.3(p=0.14)$ \\
\hline typical non-car-use & 2347 & 4 & $0.49 * * *$ & $0.39,0.59$ & 93.3 & - \\
\hline actual non-car-use & 1153 & 3 & $0.50 * * *$ & $0.34,0.66$ & 97.2 & - \\
\hline Non-car-use Intentions & 3493 & 8 & $0.48 * * *$ & $0.35,0.61$ & 97.3 & $11.8(p=0.18)$ \\
\hline$* p<.05, * * p<.01, * * * p<.001$ & & & & & & \\
\hline
\end{tabular}

Table 1. Results of the meta-analysis of non-car-use 